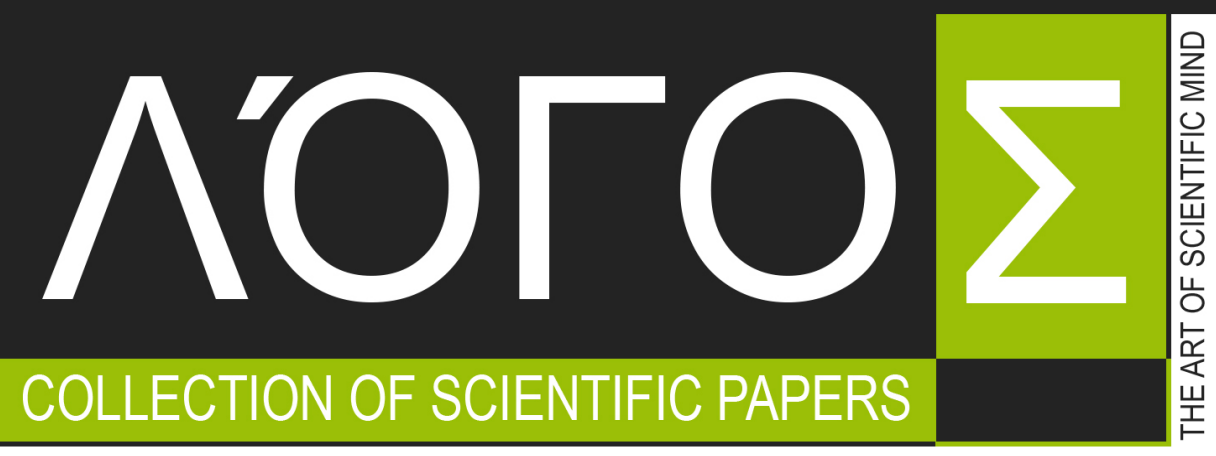

WITH PROCEEDINGS OF THE INTERNATIONAL SCIENTIFIC AND PRACTICAL CONFERENCE

PROBLEMS AND PROSPECTS OF IMPLEMENTATION OF INNOVATIVE RESEARCH RESULTS

DECEMBER 13, 2019 • VALLETTA, MALTA ש

\title{
VOLUME 4
}

DOI 10.36074/13.12.2019.v4

ISBN 978-617-7171-91-0

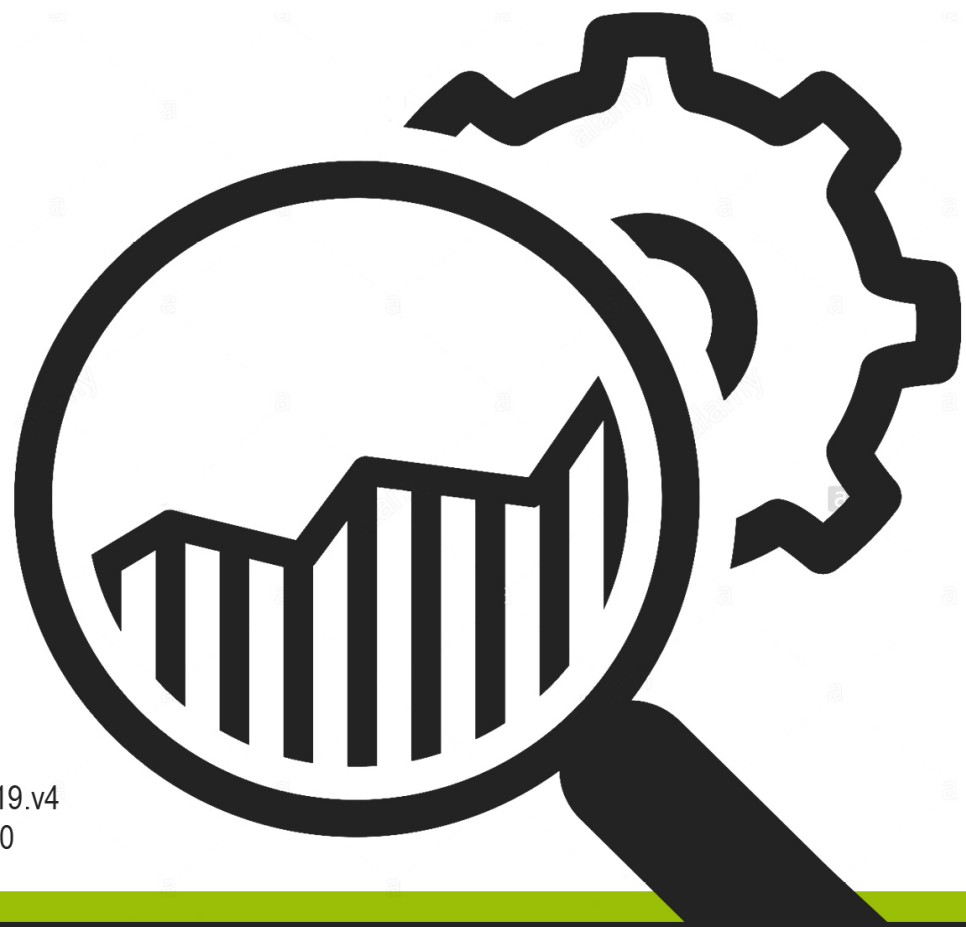



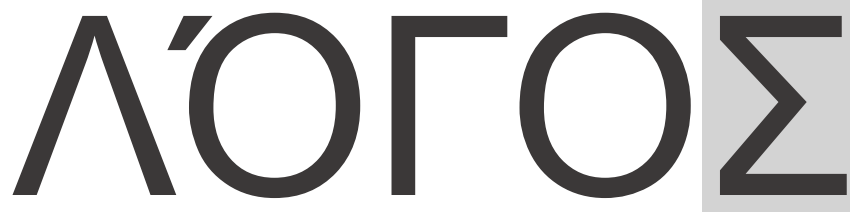

COLLECTION OF SCIENTIFIC PAPERS

WITH PROCEEDINGS OF THE INTERNATIONAL SCIENTIFIC AND PRACTICAL CONFERENCE «PROBLEMS AND PROSPECTS OF IMPLEMENTATION OF INNOVATIVE RESEARCH RESULTS»

DECEMBER 13, 2019

VOLUME 4

Valletta $\bullet$ Republic of Malta 
P 93

Chairman of the Organizing Committee: Holdenblat M.

Responsible for the layout: Kazmina $\mathrm{N}$.

Responsible designer: Bondarenko I.

P 93 Problems and prospects of implementation of innovative research results: collection of scientific papers "АОГО $\Sigma$ » with Proceedings of the International Scientific and Practical Conference (Vol. 4), December 13, 2019. Valletta, Republic of Malta: European Scientific Platform NGO.

ISBN 978-617-7171-91-0

DOI 10.36074/13.12.2019.v4

Papers of participants of the International Multidisciplinary Scientific and Practical Conference «Problems and prospects of implementation of innovative research results», held in Valletta, December 13, 2019, are presented in the collection of scientific papers.

The conference is included in the catalog of International Scientific Conferences, approved by ResearchBib and certified by Euro Science Certification Group (SCC-2000).

Conference proceedings are publicly available under terms of the Creative Commons Attribution 4.0 International License (CC BY 4.0).

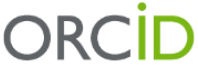

Connecting Research and Researchers

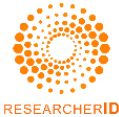

RESEARCHERID
Bibliographic descriptions of the conference proceedings are available for indexation by ORCID, Publons, Google Scholar, ets.

(C) Participants of the conference, 2019 


\section{SECTION XII.}

\section{CONTENT}

\section{LAW}

COORDINATION NORMS IN MALTA'S CONSTITUTIONAL LAW

Maksurov A.

THE PROBLEM OF CORRUPTION IN THE MODERN WORLD AND HUMAN RIGHTS

Savela V.

АКТУАЛЬНІ ПИТАННЯ ПРАВОВОГО РЕГУЛЮВАННЯ ВИКОРИСТАННЯ АЛЬТЕРНАТИВНИХ ДЖЕРЕЛ ЕНЕРГІЇ В УКРАÏHI

Оскерко-Рославлєва А.P.

ДЕРЖАВА ЯК ОСНОВНИЙ СУБ'ЄКТ МІЖНАРОДНОГО ПРАВА

Стахівський В.P.

ЗАБЕЗПЕЧЕННЯ ОСОБИСТОЇ БЕЗПЕКИ ПОЛІЦЕЙСЬКОГО ПІД ЧАС ВИКОНАННЯ СЛУЖБОВИХ ОБОВ'ЯЗКІВ

Біліченко В.В.

ЗАСТОСУВАННЯ ПРАВИЛА 39 РЕГЛАМЕНТУ ЄВРОПЕЙСЬКОГО СУДУ З ПРАВ ЛЮДИНИ У МІЖДЕРЖАВНИХ СПОРАХ Футорянська К.П.

ЗАСТОСУВАННЯ СТРОКІВ ЗВЕРНЕННЯ ДО СУДУ ПРИ ВИРІШЕННІ СПРАВИ СУДАМИ

Пархуць В.Д.

ІНФОРМАЦІЙНІ РЕСУРСИ ЯК КРИТИЧНО ВАЖЛИВА ІНФРАСТУКТУРА: ОКРЕМІ ПИТАННЯ ПРАВОВОГО РЕГУЛЮВАННЯ

Козирчук I.B.

МОЖЛИВІСТЬ ВІДТВОРЕННЯ ЕЛЕКТРОННИМ КОНОСАМЕНТОМ ФУНКЦІЙ ПАПЕРОВОГО: МІЖНАРОДНО-ПРАВОВИЙ АСПЕКТ

Ткач О.О.

НАЛЕЖНИЙ РІВЕНЬ ПРАВОВОЇ ДОПОМОГИ ЯК ГАРАНТІЯ ПРАВА НА ЗАХИСТ

Кулинич А.Ю.

ОСОБЛИВОСТІ РОЗВИТКУ АВІАЦІЙНОЇ ПРОМИСЛОВОСТІ В УКРАЇНІ ТА ІІЇ ГОСПОДАРСЬКО-ПРАВОВЕ ЗАБЕЗПЕЧЕННЯ 
4 • Problems and prospects of implementation of innovative research results $\bullet$ Volume 4

ОСОБЛИВОСТІ РОЗВИТКУ КРИМІНАЛЬНОГО ЗАКОНОДАВСТВА У ЧАСТИНІ РЕГУЛЮВАННЯ ВІДПОВІДАЛЬНОСТІ ЗА БЕЗДІЯЛЬНІСТЬ ВІЙСЬКОВОЇ ВЛАДИ З ЧАСІВ ЛИТОВСЬКИХ СТАТУТІВ І ДО СЬОГОДЕННЯ

Надоєв А.A.

ПРАВОВЕ ЗАБЕЗПЕЧЕННЯ ОБРОБЛЕННЯ ПОБУТОВИХ ВІДХОДІВ ПРИ ЇХ ЗАХОРОНЕННІ ЯК УМОВА ПІДВИЩЕННЯ ЯКОСТІ ЖИТТЯ

Трегуб O.A.

ПРАВОВЕ РЕГУЛЮВАННЯ КОНТЕНТУ В МЕРЕЖІ ІНТЕРНЕТ У НІМЕЧЧИНІ ТА УКРАЇНІ: ПОРІВНЯЛЬНИЙ АСПЕКТ

Кулинич А.Ю.

ПРОБЛЕМАТИКА МІЖНАРОДНОЇ ВІДПОВІДАЛЬНОСТІ ООН У РАЗІ НЕПРАВОМІРНОГО ЗАСТОСУВАННЯ СИЛИ

Коба I.B.

СПІВВІДНОШЕННЯ НОРМ ПРАВА ТА НОРМ ПОВЕДІНКИ ПЕРВІСНОГО СУСПІЛЬСТВА

Біліченко В.В.

СПІЛЬНА АГРАРНА ПОЛІТИКА ЄС: ОСНОВНІ НАПРЯМКИ РОЗВИТКУ НА 2020-2027 РОКИ

Кулинич А.Ю.

СУБ'ЄКТИВНА СТОРОНА ЗЛОЧИНІВ ПРОТИ ЖИТТЯ ТА ЗДОРОВ'Я ОСОБИ, ВЧИНЕНИХ НА ГРУНТІ НЕНАВИСТІ

Казарян Е.Г.

ТРУДОВА МІГРАЦІЯ: ПРОБЛЕМА СЬОГОДЕННЯ

Горб О.С.

ЩОДО МІЖНАРОДНОЇ ПРАВОСУБ'ЄКТНОСТІ НАЦІЙ

Пархуць В.Д.

ЩОДО ПОНЯТТЯ НОВОВИЯВЛЕНИХ ОБСТАВИН, ЇХ ВІДМЕЖУВАННЯ ВІД НОВИХ ОБСТАВИН

Возняковська К.А. 58

SECTION XIII.

HISTORY

АКТУАЛЬНІ ПИТАННЯ ГУРТКОВОЇ РОБОТИ У СУЧАСНИХ НАУКОВИХ РОЗРОБКАХ

Варсан-Карапаскал В.В. 
ДО ПИТАННЯ ПРО ВЖИВАННЯ УКРАЇНСЬКОЇ МОВИ У КІНЕМАТОГРАФІ НАПРИКІНЦІ 1980-х рр.

Абакумова В.І.

ЕВОЛЮЦІЯ ЖІНОЧИХ ОБРАЗІВ У ПОСТМОДЕРНІЙ МОДІ США 4070 PP. XX CT.

Дутканич В.C.

ЄВРОПЕЙСЬКА МІГРАЦІЙНА КРИЗА ЯК ВИКЛИК СУЧАСНОСТІ

Руда В.В.

ІСТОРІЯ ФОРМУВАННЯ УКРАЇНСЬКОЇ КУХНІ

Орлова Г.

ОБСІВАННЯ ТРАДИЦІЙНОЇ ПОКУТСЬКОЇ САДИБИ НА ЩЕДРИЙ BEЧIP

Досінчук С.Ю., Соловей У.Б.

\section{SECTION XIV. POLITICS}

ПОЛІТИЧНИЙ АНАЛІЗ КОРЕЙСЬКОЇ ВІЙНИ 1950-1953 РР. ТА ЇЇ ВПЛИВ НА РОЗВИТОК СУЧАСНИХ ПОДІЙ НА КОРЕЙСЬКОМУ ПIВOCТРОВІ

Петрова К.О.

\section{SECTION XV. GEOGRAPHY}

АНАЛІЗ ПРОЦЕСІВ РУСЛОФОРМУВАННЯ НА РІЧЦІ ВОРСКЛА Тепайкіна Д.В.

\section{SECTION XVI.}

ARCHITECTURE AND ARTS

ATRIUM IN THE STRUCTURE OF HEALHCARE INSTITUTION Konoplyova O., Bondarenko A.

AUGMENTED REALITY: FUNCTIONS, DIRECTIONS OF APPLICATION

Research group:

Kryvuts S., Gonchar O., Popova O.

ДНІПРО ЯК ПРЕДМЕТ АРХІТЕКТУРИ

Гулієв Л.М. 
6 Problems and prospects of implementation of innovative research results $\bullet$ Volume 4

ДОЖДЕВЫЕ САДЫ КАК СОСТАВЛЯЮЩАЯ ЧАСТЬ УСТОИЧИВОГО РАЗВИТИЯ ГОРОДА

Киселёва А.В., Крамаренко М.О.

ШРИФТ У КОНЦЕПЦІЇ НЕОПЛАСТИЦИЗМУ

Ісмайлова М.С.

SECTION XVII.

MILITARY SCIENCES, NATIONAL SECURITY AND SPORT

ОСОБЛИВОСТІ ПРОЦЕСУ ПРИЙНЯТТЯ РІШЕНЬ В УМОВАХ НЕСТОХАСТИЧНОÏ НЕВИЗНАЧЕНОСТІ

Науково-дослідна група:

Королюк Н.О., Голубничий Д.Ю., Коршець О.А., Першин О.В., Маслійова С.О. 


\title{
SECTION XII. LAW
}

\section{COORDINATION NORMS IN MALTA'S CONSTITUTIONAL LAW}

\author{
Aleksei Maksurov \\ Ph.D. (Law), Professor ${ }^{1}$, Lecturer ${ }^{2}$
}

Yaroslavl State University named after P.G. Demidova

RUSSIAN FEDERATION

School of Law, Sorbonne University of Paris

FRENCH REPUBLIC

For the first time applied a coordination approach to the consideration of legal phenomena, thanks to which one can explore legal phenomenon from a new angle of view. The above mentioned gives opportunity in this case to improve the effectiveness of legal action.

Usually the coordination rules of law are not the subject of a separate study. Such a study performed by the author on the example of the legislation of the countries of Europe, using a wide range of legal material [1].

The research allowed to develop recommendations for improving the effectiveness of law due to the streamlining of coordination norms. Made of demarcation rules on the coordination and norms of cooperation, collaboration and other forms of interaction. Updated legal terminology. The proposed use of the coordination rules to certain legislative acts of the countries of Europe.

The last decade has seen increased interest as representatives of science and practitioners to the category of "coordination". Such attention is not accidental. It is the phenomenon of coordination allows us to solve seemingly intractable problems, to mitigate the significant contradictions objectively arise between people in the course of their daily activities.

Constitution of the Republic of Malta [2] does not contain particularly significant coordination standards. Nevertheless, they are there.

More often than not, we are talking about "norms of consent".

Thus, according to Article 26 (2) (a) of the Constitution, from August 1, 1989 no one should have the right to register as a citizen of Malta on the basis of this article, unless: (a) the Minister agrees that the granting of citizenship to such a person is not contrary to the public interest...

In accordance with Article 77 of the Constitution, general elections of members of the House of Representatives must be held at such a time within three months after any dissolution of Parliament, which the President, acting in agreement with the Prime Minister's Council, should appoint by his announcement.

By virtue of subparagraph "b" of paragraph 3 of Article 81 of the Constitution, the minister's position, unlike the post of prime minister, should become vacant: if his appointment to this post was canceled by the President acting in agreement with the council of the prime minister.

Coordination is also required by the direct activities of the authorities themselves. Thus, on the basis of paragraph 2 of Article 78 of the Constitution, the executive power of Malta must be exercised by the President, both directly and 
through subordinate officials, in accordance with the requirements of this Constitution.

Coordination is important in terminology! Thus, article 47, paragraph 1, of the Constitution states that in this chapter, except where the context requires otherwise, the following expressions should have the following meanings respectively, that is: "contravention" in relation to any requirement includes the absence of subordination this requirement, related expressions should be understood in a consistent manner.

\section{References:}

1. Maksurov A.A. Coordination in legal systems of the countries of Europe. Part II. - M., 2018. P.3.

2. Constitution of the Republic of Malta // http://worldconstitutions. ru/?p=145

\section{THE PROBLEM OF CORRUPTION IN THE MODERN WORLD AND HUMAN RIGHTS}

Veronika Savela

student of Law faculty

National Aviation University

SCIENTIFIC ADVICER:

Natalia Semchuk

senior lecturer of the Department of criminal law and procedure, candidate of law, lawyer National Aviation University

UKRAINE

One of the most pressing problems in the world is corruption. Corruption can jeopardize the existence of an economic system and civil society that is in its infancy. It is necessary to abandon the simplified perception of the problem as a manifestation of unsatisfactory management or improper implementation of legal regulations by persons authorized to perform the functions of the state [1].

Therefore, overcoming corruption becomes an extremely difficult problem because corruption phenomena restrict the rights and freedoms of man and citizen.

According to the Law of Ukraine "On prevention of corruption", corruption is the use by a person of his / her official powers and related opportunities in order to obtain improper benefits [2].

Common types of corruption are bribery, fraud, extortion, abuse, nepotism, etc., for example, the use of information obtained during the performance of official duties, for selfish or other personal interests, unjustified refusal to provide relevant information, its untimely provision, provision of inaccurate or incomplete official information; unlawful interference with the use of official position in the activities of other state bodies or officials in order to prevent them from exercising their powers or harassment of illegal decision-making. Corruption acts may also be committed in other forms, including those requiring additional definition by the legislation. Thus, the circle of corruption crimes can be divided into 2 groups. According to the 
Criminal Code, the first group includes acts which, in their "pure" form, do not constitute corruption, but can be classified as such only with regard to their perpetration by certain categories of persons determined at the level of part 3 and 4 art. 18 of the Criminal Code of Ukraine and notes to art. 364 of the Criminal Code of Ukraine. The second group of criminally punishable acts, which are classified as corruption, are actually corruption crimes, which contain only an illegal corruption component. For example, misuse of budget funds, implementation of budget expenditures or the provision of loans from the budget without established budget appointments or exceeding them; bribery of an employee of an enterprise, institution or organization; abuse of power or official position; abuse of authority; acceptance of an offer, promise or improper benefits by an official; illegal enrichment; abuse of influence and bribery [4].

For committing corruption offenses, persons are brought to criminal, administrative, civil and disciplinary responsibility in accordance with the procedure established by law [2].

Therefore, corruption is an extremely negative phenomenon, its public danger is that it significantly undermines the authority of the state, damages the establishment of democratic foundations of governance, the construction and functioning of the state apparatus. Corruption acts substantially restrict the constitutional rights and freedoms of man and citizen, violate the rule of law and social justice [3].

In my opinion, corruption is one of the main factors that pose a real threat to security, democratic development of the state and society, the constitutional system. Corruption primarily undermines the authority of the country, harms the democratic foundations of governance of society, the functioning of the state apparatus, limits the constitutional rights and freedoms of man and citizen, especially ordinary people, violates the principles of the rule of law, deepens inequality, undermines public administration, provokes irresponsibility of officials and distrust of citizens. Bribery is an obstacle to the realization of all human rights: civil, political, economic, cultural, in general - the right to personal development. Corruption hinders the development of the legal system, making it impossible for Ukraine to approach the world's leading indicators of living standards. Corruption phenomena lead to inhibition of social and economic reforms, hinder the development of market relations. Corruption contributes to the criminalization and shadowing of economic relations, legalization of income obtained illegally, complicates relations with other states and the entire international community, makes it impossible to provide foreign assistance. The presence of corruption phenomena limits society in the enjoyment of its legitimate rights and interests. That is why counteraction corruption is one of the priorities of the state.

At the present stage of development of society and functioning of the state mechanism, the problem of corruption has become urgent and inevitable. This negative factor seriously aggravates the crisis of confidence in the state, its power structures, nullifies their authority and public activity of the person, contributes to a significant weakening of the rule of law, completely destroys the foundations of statehood and morality. Overcoming corruption is a necessary condition for strengthening Ukraine's economy and ensuring the inviolability of constitutional human rights. 


\title{
References:
}

1. Концепція подолання корупції в Україні "На шляху до доброчесності" (Указ президента України). (2006). Вилучено 3: https://minjust.gov.ua/m/str_7094.

2. Про запобігання корупції (Закон України). № 1700-VII. ( 2014 ). Вилучено з: https://zakon.rada.gov.ua/laws/show/1700-18.

3. Про Концепцію боротьби з корупцією на 1998-2005 роки (Указ президента України). № 367/98.(1998). Вилучено з https://zakon.rada.gov.ua/rada/show/367/98?lang=uk.

4. Кримінальний кодекс України: Відомості Верховної Ради України (ВВР), 2001, № 25-26, ст.131. Вилучено 3 https://zakon.rada.gov.ua/laws/show/2341-14/stru\#Stru.

\section{АКТУАЛЬНІ ПИТАННЯ ПРАВОВОГО РЕГУЛЮВАННЯ ВИКОРИСТАННЯ АЛЬТЕРНАТИВНИХ ДЖЕРЕЛ ЕНЕРГІІ В УКРАÏHI}

\author{
Оскерко-Рославлєва Анна Русланівна \\ здобувач вищої освіти \\ Полтавського юридичного інституту \\ Національний юридичний університет імені Ярослава Мудрого \\ НАУКОВИЙ КЕРІВНИК: \\ Троцька Марина Василівна \\ канд. юрид. наук, доцент кафедри конституційного, \\ адміністративного екологічного та трудового права \\ Полтавського юридичного інституту \\ Національний юридичний університет імені Ярослава Мудрого \\ УКРÄ̈HA
}

Енергетика виступає фрундаментом існування будь-якого сучасного індустріального суспільства. Життя сучасної людини, функціонування промисловості зараз неможливо уявити без енергії, енергетичних продуктів та послуг. Нині паливо-енергетичний комплекс стикається з великою кількістю різноманітних викликів та проблем, зокрема скороченням та виснаженням паливних корисних копалин, ускладненням їх геологорозвідки та видобутку, екологічними проблемами, пов'язаними 3 діяльністю електростанцій традиційних типів (перш за все, викиди парникових газів в атмосферу).

Вирішити ці проблеми можливо шляхом переходу до використання альтернативних відновлювальних джерел енергії. Однак слід враховувати, що без належної нормативно-правової бази, відповідних правових засобів розвиток цієї сфери неможливий.

Питанням правового регулювання використання альтернативних джерел енергії в Україні приділялась увага в багатьох працях науковців: Пипяк М., Кременовської І.В., Чіпко М.В. та ін.

Відповідно до резолюції №33/148 Генеральної асамблеї ООН (1978р.) до нетрадиційних і поновлюваних джерел енергії відносяться: сонячна, вітрова, геотермальна, енергія морських хвиль, припливів і океану, енергія біомаси, 
деревини, деревного вугілля, торфу, тяглової худоби, сланців, бітумінозних пісковиків і гідроенергія великих та малих водотоків. Міжнародне Енергетичне Агентство (MEA) визначає такі джерела її як енергію, отриману з сонця, вітру, біомаси, геотермальних, гідроенергетичних та океанських ресурсів, а також твердої біомаси, біогазу та рідких біопалив. [1].

Тобто визначення поняття альтернативних джерел енергії дається через просте перелічення можливих її різновидів. Аналогічне визначення міститься і в українському законодавстві.

Відповідно до ст. 1 Закону України «Про альтернативні джерела енергії» (далі - ЗУ «Про альтернативні джерела енергії») [2]: альтернативні джерела енергії - відновлювані джерела енергії, до яких належать енергія сонячна, вітрова, геотермальна, гідротермальна, аеротермальна, енергія хвиль та припливів, гідроенергія, енергія біомаси, газу з органічних відходів, газу каналізаційно-очисних станцій, біогазів, та вторинні енергетичні ресурси, до яких належать доменний та коксівний гази, газ метан дегазації вугільних родовищ, перетворення скидного енергопотенціалу технологічних процесів.

Такий підхід не можна визнати вдалим, оскільки через відсутність рис, характерних саме для цього виду енергії, стримується розвиток джерел, які не вказані в наведеній статті.

Світовий досвід показує, що одним із перспективних шляхів збільшення частки енергії, виробленої з відновлювальних джерел, $є$ формування дієвого механізму стимулювання та практичного використання цієї енергії. Нині у багатьох країнах світу проводиться заохочувальна політика, вводиться економічний механізм стимулювання у сфері використання відновлювальних джерел енергії. Для цього виробникам «чистої енергії» держава надає пільги. Основними формами такої підтримки є: - субсидії, кредити по відсотковим ставкам; - гарантії за банківськими позиками; - встановлення фіксованих закупівельних цін на енергію, що виробляється на основі відновлювальних джерел; - звільнення від сплати податку на частку доходу, інвестованого в нетрадиційну енергетику; - надання режиму прискореної амортизації; фінансування науково-дослідницьких та дослідно-конструкторських робіт в галузі нетрадиційної енергетики [3].

В Україні існує так званий «зелений тариф», який передбачає купівлю державою електроенергії, виробленої на альтернативних джерелах (крім джерел енергії доменного і коксівного газу) за завищеним тарифом. За ст. 1 ЗУ «Про альтернативні джерела енергії»: «зелений» тариф - спеціальний тариф, за яким закуповується електрична енергія, вироблена на об'єктах електроенергетики, зокрема на введених в експлуатацію чергах будівництва електричних станцій (пускових комплексах), з альтернативних джерел енергії (a 3 використанням гідроенергії - лише мікро-, міні- та малими гідроелектростанціями). Його застосування регулюється Порядком встановлення, перегляду та припинення дії «зеленого» тарифу на електричну енергію для суб'єктів господарської діяльності, споживачів електричної енергії, у тому числі енергетичних кооперативів, та приватних домогосподарств, генеруючі установки яких виробляють електричну енергію з альтернативних джерел енергії, затвердженим постановою Національної комісії, що здійснює державне регулювання у сферах енергетики та комунальних послуг (далі НКРЕКП) [4] та Постановою НКРЕКП «Про встановлення «зелених» тарифів на електричну енергію та надбавки до «зелених» тарифів за дотримання рівня 
використання обладнання українського виробництва для суб'єктів господарювання» [5].

В механізмі його функціонування для юридичних осіб можна виділити дві бюрократичні перешкоди: по-перше, для підтвердження походження електричної енергії, виробленої на альтернативних відновлювальних джерелах, суб'єкту господарської діяльності - виробнику такої енергії на його запит Держенергоефективності України видає гарантію походження електричної енергії; по-друге, хоча діяльність по виробництву електроенергії без ліцензії дозволяється (при використанні обладнання потужністю менше, ніж $10 \mathrm{MBT})$, але якщо виробник має намір продавати електроенергію на оптовому ринку («зелений» тариф оформлюється тільки на реалізацію електроенергії державі на оптовому ринку), то він зобов'язаний отримати ліцензію. Для фізичних осіб також встановлено обмеження - без ліцензії дозволяється використання обладнання потужністю менше 150 КВт [6].

Пипяк М. вказує й на інші недоліки системи стимулювання розвитку альтернативних джерел енергії, а саме перешкоди на шляху залучення іноземних інвестицій. Зокрема, корупційна складова системи державного управління. Дієвим інструментом, на його думку, має стати нова форма співпраці, яка ґрунтується на принципах публічно-приватного партнерства, що дасть змогу державі, уникаючи безпосереднього втручання в господарську діяльність підприємства, за допомогою інструментів нормативно-правового, фінансово-економічного, адміністративно-правового та інформаційнокомунікативного механізмів державного регулювання сприяти створенню нових потужностей для виробництва енергоносіїв з альтернативних джерел енергії [7].

Окрім того, відсутність зацікавленості міжнародних фінансових організацій в інвестуванні в альтернативну енергетику України $\epsilon$ наслідком побоювань зменшення чинного розміру «зеленого» тарифу [7].

Отже, для розвитку відновлювальної енергетики в Україні необхідно стимулювання та підтримка державою використання альтернативних джерел як в промисловості, так і в домашньому господарстві. Перш за все, необхідне впровадження нових механізмів підтримки (з урахуванням світової практики), вдосконалення існуючих («зеленого» тарифу) та належне нормативноправове регулювання. Також важливим аспектом розвитку цієї галузі $\epsilon$ залучення іноземних інвестицій.

\section{Список використаних джерел:}

1. Прокіп, А. В. (2010). Еколого-економічна оцінка заміщення невідновлювальних енергоресурсів біологічно відновлювальними. Львів: ЗУКЦ.

2. Про альтернативні джерела енергії (Закон України). № 555-IV. (2019). Вилучено 3: https://zakon.rada.gov.ua/laws/show/555-15.

3. Гудкова, Е.А., Чернышев, Л.Н. (2010). Зарубежный опыт использования возобновляемых источников энергии как основа повышения энергопродуктивности российских регионов. Вестник МГСУ, (4-1), 84-91.

4. Порядок встановлення, перегляду та припинення дії «зеленого» тарифу на електричну енергію для суб'єктів господарської діяльності, споживачів електричної енергії, у тому числі енергетичних кооперативів, та приватних домогосподарств, генеруючі установки яких виробляють електричну енергію з альтернативних джерел енергії (Постанова Національної комісії, що здійснює державне регулювання у сферах енергетики та комунальних послуг). 
№ 1817. (2019). Вилучено 3: https://zakon.rada.gov.ua/rada/show/v1817874-19 (дата звернення: 30.10.2019).

5. Про встановлення «зелених» тарифів на електричну енергію та надбавки до «зелених» тарифів за дотримання рівня використання обладнання українського виробництва для суб'єктів господарювання (Постанова Національної комісії, що здійснює державне регулювання у сферах енергетики та комунальних послуг). № 1991. (2019). Вилучено з: http://www.nerc.gov.ua/index.php?id=44630 (дата звернення: 30.10.2019).

6. Альошкіна, Н. (2016). Альтернативне джерело енергії чи який же він, цей «зелений» тариф. Налоги и бухгалтерский учёт. (81). Вилучено 3: https://i.factor.ua/journals/nibu/2016/october/issue-81/article-22270.html.

7. Пипяк, М. (2017). Напрями вдосконалення правового регулювання стимулів розвитку відновлювальної енергетики в Україні. Підприємництво, господарство і право, (10), 76-80.

\title{
ДЕРЖАВА ЯК ОСНОВНИЙ СУБ'ЄКТ МІЖНАРОДНОГО ПРАВА
}

\author{
Стахівський Владислав Русланович \\ Здобувач вищої освіти юридичного факультету \\ Дніпровський національний університет імені Олеся Гончара
}

НАУКОВИЙ КЕРІВНИК:

Ведькал Валентина Андріївна канд. ісn. наук, доцент кафедри європейського та міжнародного права Дніпровський національний университет імені Олеся Гончара УКРАÏHA

Протягом багаторічної історії міжнародного права держави були єдиними суб'єктами міжнародних відносин. Не помилкою буде і думка, що міжнародне право почало існувати саме для регулювання такого суб'єкта як Держава. Норми сучасного міжнародного права продовжують регулювати в основному відносини між державами та відносини держав з міжнародними організаціями та іншими міжнародними інститутами. Звичайно, на даному етапі розвитку людства, в міжнародному праві задіяні різні інститути, які і допомогають покращити врегулювання різних питань. Держави - основні суб'єкти міжнародного права та основні реальні учасники міжнародних відносин, оскільки їм потрібно постійно взаємодіяти між собою, з міжнародними організаціями та іншими суб'єктами міжнародного права. Міжнародне право стосується насамперед прав, обов'язків та інтересів його суб'єктів.

Слід зазначити що держава, як і будь-який інший компонент міжнародного права має свої ознаки та характеристики. В сучасному світі, а саме беручи до уваги політичні відносини на міжнародній арені, держава повинна мати три основні складові: безпосередньо територія; люди, які там проживають населення; і так звана публічна влада, маю на увазі незалежна, легітимна влада в країні, яка ефективно виконує свої обов'язки. Кожна держава володіє рівними правами по відношенню до інших, та має суверенітет. Суверенітет 
держави обмежується визначеною частиною території, яка підлягає виключній юрисдикції держави і захищена міжнародним правом від порушення з боку інших держав. Також автор зазначає, що в міжнародному праві не має абсолютного суверенітету держав. Він є обмежений і це цілком розумно, так як держави вступають в міжнародні організації, підписують та приймають різного типу акти. I звичайно, насамперед він обмежений з метою захисту прав людини та інтересів.

Як і будь який суб'єкт міжнародного права, держава має свої права та обов'язки. Посилаючись на декларацію прав та обов'язків держав, можна зробити висновок що такі пункти чітко прописані та зазначені. Держава має право: укладати міжнародні договори; брати участь у діяльності міжнародних організацій; підтримувати дипломатичні, консульські та інші зв'язки; виступати стороною у Міжнародному суді $\mathrm{OOH}$; у разі необхідності правомірно застосовувати силу відповідно до Статуту ООН.

Має повне право на здійснення юрисдикції на власній території та над усіма особами, що знаходяться в ії межах. Звичайно, слід зазначити і обов'язки держави у міжнародному праві: один із найголовніших - це мирне вирішення міжнародних спорів; не втручатися у будь-які справи (зовнішні та внутрішні) інших держав; добросовісно виконувати все міжнародні договори, які були прийняті та ратиффіковані; поважати права людини та інш.

У разі порушення міжнародно-правових зобов'язань держава як суб'єкт міжнародного права несе міжнародно-правову відповідальність, незалежно від того, який її орган або посадова особа своєю поведінкою завдали шкоду міжнародному праву. Держава повинна повністю відшкодувати будь-яку шкоду, заподіяну незаконним діянням, за яке вона несе міжнародну відповідальність. Відшкодування складається з реституції вихідної ситуації, якщо це можливо, компенсації, коли це неможливо, або задоволення (тобто визнання та вибачення за порушення), якщо жодне з них не можливе.

Слід зазначити, що держава являється одним із первинних суб'єктів міжнародного права, тому їі правосуб'єктність має загальний характер і володіє більш повним обсягом щодо інших інститутів. Правосуб'єктність інших суб'єктів міжнародного права проявляється в основному в результаті їх взаємовідносин з державами або взагалі з'являється в результаті їхньої волі. Різні міжнародні інститути, організації, виникли саме для забезпечення умов функціонування держав на міжнародній арені. Мають функції, які допомагають підтримувати мир між взаємовідносинами держав, підтримка в політичних питань, тобто іншими словами створені для регулювання та покращення тих чи інших відносин.

Отже, беручи до уваги цю інформацію, потрібно висновок, що саме Держава виступає головним суб'єктом в міжнародному праві. Являється первинним джерелом, і так чи інакше вплинула на розвиток ситуації в міжнародному праві.

\section{Список використаних джерел:}

1. Шемшученко, Ю. С. (ред.). (2044). Юридична енциклопедія у 6 m. (Т. 6: Т.Я). Київ: Укр. енцикл..

2. Римский статут Международного уголовного суда от 17 июля 1998 г.

3. Висновок Конститучійного Суду України у справі за конституційним поданням Президента України про надання висновку щодо відповідності Конституції України 
Римського Статуту Міжнародного кримінального суду (справа про Римський Статут) №

3 в.2001 від 11 липня 2001 р. Офіц. вісн. України. 2001. № 28. Ст. 1267.

\title{
ЗАБЕЗПЕЧЕННЯ ОСОБИСТОЇ БЕЗПЕКИ ПОЛІЦЕЙСЬКОГО ПІД ЧАС ВИКОНАННЯ СЛУЖБОВИХ ОБОВ'ЯЗКІВ
}

\author{
Біліченко Валерій Віталійович \\ старший викладач кафедри тактико-спеціальної підготовки \\ Дніпропетровський державний університет внутрішніх справ \\ УКРАÏHA
}

Безпека працівника Національної поліції дуже важлива в повсякденні. Це зумовленою низкою різноманітних причин, в тому числі відношенням працівника до служби, до забезпечення власної безпеки, дотриманням правил носіння зброї, спеціальних засобів тощо.

Причини травмувань, каліцтва та загибелі поліцейських різноманітні.

До них відносять:

- недостатню психологічну підготовку (страх застосування/використання зброї);

- відсутність висококваліфікованих кадрів;

- недостатнє матеріальне забезпечення;

- небажання звертатися за допомогою до своїх колег (бажання бути героєм/лідером).

Іноді звичайна перевірка документів, може стати останньою для поліцейського. Для мінімізації ризику бути жертвою, необхідно вміти діяти 3 напарником, прикривати його. Оскільки, сучасна злочинність дуже розвинена, то при затриманні вони чинять відчайдушний опір [5].

При виконанні службових обов'язків, пов'язаних з затриманням злочинців (особливо в яких можливо знаходиться зброя) необхідно бути дуже уважним та пильним. Дотримання правил особистої безпеки гарантує зниження ризику. Дуже важливою складовою $є$ знання законодавчої бази для поліцейського, а також вмінням знаходити комунікацію з будь яким громадянином.

Національна поліція України, намагається встановити тісний зв'язок 3 населенням (створення проекту «Офріцер громади»), сформувати у громадян позитивний імідж поліції (ЗМІ часто висвітлює добрі та прості вчинки поліцейський, у тому числі і курсантів), а також максимально створити умови захищеності (проект «Безпечне місто).

Значною проблемою забезпечення особистої безпеки поліцейських $є$ фрінансові складнощі держави та поки що не достатній матеріально-технічний рівень забезпеченості працівників [1].

Слід наголосити, що будь-які організаційно-правові матеріально - технічні, управлінські та інші заходи не можуть бути ефективними без усвідомлених і цілеспрямованих зусиль самого працівника [2].

Небезпека, яку зазнають працівники поліції під час виконання службових завдань, $є$ різноманітною за змістом, силою впливу, наслідками для здоров'я 
та іншими характеристиками. Практика показує, що забезпечення безпеки діяльності працівників підрозділів Національної поліції ще не знаходиться на належному рівні, оскільки щорічно гине та отримує тяжкі поранення, каліцтво, психічний розлад та закінчує життя самогубством значна кількість поліцейських [1].

Цілі, функції та завдання які покладаються на Національну поліцію, а також вимоги, що висуваються до поліцейських, зумовлюють виникнення під час службово-трудової діяльності небезпечних факторів, які знижують безпеку працівників. Під час службової діяльності поліцейськом доводиться діяти в умовах, які відчутно впливають на стан його здоров'я, життя, рівень працездатності та на якість виконання поставлених завдань. У діяльності поліцейських надзвичайно часто виникають обставини, що створюють значні труднощі в роботі й водночас вимагають від них як представників влади швидких, точних та безпомилкових дій.

Доцільно наголосити, що діяльність поліцейських переважно пов'язана 3 ризиком для життя та здоров'я і здійснюється в конфліктних, а досить часто й в екстремальних умовах, що значною мірою впливає не тільки на результати виконання завдань, а й на особисті якості людини [3].

Найголовнішою проблемою сьогодення - $\epsilon$ низька стресостійкість. Це зумовлено поганою психологічною підготовкою, низьким рівнем соціального захисту, іноді можуть бути фінансові проблеми, відсутність необхідного для організму людини відпочинку (адже особливо у оперативних співробітників ненормований робочий день), упереджене ставлення з боку керівника орагну поліції, невлаштованість побуту, недосконалість законодавства (закон в більшій мірі захищає права правопорушника ніж потерпілого чи поліцейського), а також посягання на особу поліцейського та його власність у зв'язку 3 професійною діяльністю [4]. Україна намагається створити достойні умови праці для поліції. Це $є$ і поміч з боку громадських організацій, і боротьба зі злочинами через мережу Інтернет, і закупівля нового сучасного обладнання. Але, через суб'єктивні фактори, деякі працівники поліції допускають у своїй діяльності недбале й пасивне виконання своїх обов'язків, легковажність, втрата професійної мотивації до роботи, перевищення владних повноважень, зловживання службовим становищем [5].

Для підвищення свого професійного рівня не достатньо знати тільки особливості діяльності своїх українських колег, а ще необхідно вивчати досвід зарубіжних країн, зокрема держав-учасниць НАТО.

Наша держава, дуже часто запрошує іноземців для проведення занять 3 поліцейськими різних служб. Для мінімізації ризику, необхідно відвідувати тренінги та семінари для підвищення свого рівня знань в даній сфері.

\section{Список використаних джерел:}

1. Vlasenko, I.V. (2009) Doslidzhennia ryzyku pratsivnykiv militsii. Pravo i bezpeka (5), 223-226. [українська]

2. Kazmirenko, L.I. (2009) Systema i struktura yurydychnoi psykholohii. Filosofski, metodolohichni ta psykholohichni problemy prava: proceedings of the $4^{\text {th }}$ All Ukrainian Scientific and Practical Conference (28 sichnia 2009, Kyiv, Ukraina). [українська]

3. Lishchuk, B.V. (2016) Osobysta bezpeka yak vazhlyva skladova v sluzhbovii diialnosti politseiskykh. Naukovyi visnyk: LDUVS (4), 204.-2011. [українська]

4. Androsiuk, V.V. (1995) Profesiina psykholohiia v OVS. Zahalna chastyna: kurs lektsii. V. Androsiuk, L. Kazmirenko, V. Medvediev - Kyiv: UAVS. 
5. Zabezpechennia okhorony pratsi ta osobystoi bezpeky v Natsionalnii politsii Ukrainy (2017). DDUVS: Lira LTD.

DOI 10.36074/13.12.2019.v4.01

\title{
ЗАСТОСУВАННЯ ПРАВИЛА 39 РЕГЛАМЕНТУ ЄВРОПЕЙСЬКОГО СУДУ 3 ПРАВ ЛЮДИНИ У МІЖДЕРЖАВНИХ СПОРАХ
}

\author{
Футорянська Катерина Павлівна \\ магістрант за спеціальністю міжнародне право \\ Інститут міжнародних відносин \\ Київського національного університету ім. Тараса Шевченка
}

НАУКОВИЙ КЕРІВНИК:

Поєдинок Ольга Романівна

Кандидат юридичних наук, доцент, доцент кафедри міжнародного права

Інститут міжнародних відносин

Київського національного університету ім. Тараса Шевченка

УКРӒ̈̈А

Європейський суд 3 прав людини (надалі - ЄСПЛ) $€$ одним із найбільш ефрективних механізмів з захисту прав людини в Європі. Офіційні статистичні дані показують, що з 1959 року по 2018 рік ЄСПЛ виніс рішення у 21600 справах щодо порушення основних прав та свобод людини. $40 \%$ рішень стосуються трьох держав-членів Ради Європи - Туреччина (3532 рішень), Російська Федерація (2501 рішень), Італія (2396 рішень) [1].

Процедура захисту прав людини в рамках ЄСПЛ полягає в тому, що Європейський суд з прав людини приймає до розгляду як індивідуальні, так й міждержавні заяви щодо порушення основоположних прав та свобод людини, що закріплені у «конституційному документі європейського публічного порядку» - Європейський конвенції з прав людини.

Серед вищезазначених процедур захисту прав людини найбільш поширеними у практиці ЄСПЛ є індивідуальні скарги. Так, офріційна статистика Суду демонструє, що за 2018 рік до ЄСПЛ було подано 43100 індивідуальні заяви, хоча 29300 з них було направлено на розгляд суддею одноособово 3 ймовірністю визнання неприйнятними [2].

Ситуації, коли держава звертається з заявою проти іншої держави, трапляються у міжнародній практиці надзвичайно рідко й лише у разі, коли $є$ масове та систематичне порушення прав та свобод людини. За всю практику ЄСПЛ до Суду було подано лише 24 міждержавні заяви.

Однак, розгляд заяв щодо порушення прав людини темпорально $\epsilon$ тривалою процедурою. У разі систематичного порушення прав людини та нагальної необхідності реагування потрібна негайна відповідна реакція. Для таких ситуацій існує механізм тимчасових заходів (interim measures), який закріплений Правилом 39 Регламенту Європейського суду з прав людини. Так, Палата або, коли це доцільно, її Голова може - на прохання сторони чи будь- 
якої іншої заінтересованої особи або з власної ініціативи - вказати сторонам, який тимчасовий захід, на її думку, слід вжити в інтересах сторін або в інтересах належного провадження у справі [3]. У справі Маматкулов та Аскаров проти Туреччини (Mamatkulov and Askarov v.Turkey) Суд зазначив, що тимчасові заходи вживаються лише коли існує ризик заподіяння невиправданої шкоди [4].

Тимчасові заходи $€$ не лише інструментом реагування на кричуще порушення прав людини у індивідуальному порядку, але також є ефективним механізмом у міждержавних спорах. Однак, як й у ситуації з розглядом заяв, кількість тимчасових заходів у індивідуальних випадках набагато більше, ніж у міждержавних зверненнях.

Перший запит на застосування тимчасових заходів у міждержавних справах був зроблений у 1957 році у справі Греція проти Туреччини. Так, Греція звернулась до ЄСПЛ з запитом щодо вжиття тимчасових заходів Великою Британією щодо особи, яка була захоплена владою Сполученого Королівства та засуджена до смертного покарання.

Серед інших прикладів застосування Правила 39 Регламенту Європейського Суду з прав людини можна назвати справу Грузія проти Російської Федерації (Georgia v. Russian Federation (II)). Так, 11 серпня 2008 року Грузія звернулась до ЄСПЛ у зв'язку із масовим порушенням прав людини під час збройного конфрлікту між Грузією та Росією. У заяві зазначалось, що під час нападів Російської Федерації, а також сепаратистських угрупувань, які підтримуються Російською Федерацією, сотні цивільних осіб було поранено, вбито, затримано або пропало безвісти, знищено майно тисячі осіб, більше 300000 осіб були змушені залишити Абхазію та Південну Осетію [5]. ЄСПЛ закликав обидві держави вжити тимчасові заходи 3 метою виконання державами своїх обов'язків, які закріплені та гарантовані Європейською Конвенцією з прав людини.

У контексті заяв України проти Російської Федерації, Європейський суд 3 прав людини також неодноразово приймав рішення про застосування Правила 39 Регламенту ЄСПЛ. Так, 13 березня 2014 року Уряд України звернувся до ЄСПЛ із заявою проти Російської Федерації (Ukraine v. Russian Federation (re Crimea)). У заяві Україна зазначала про необхідність вжиття тимчасових заходів. Зокрема, Україна вказувала на необхідність утримання Російською Федерацією від заходів, які можуть призвести до загибелі або поранення цивільного населення на території України. ЄСПЛ прийняв рішення про необхідність застосування Правила 309 Регламенту Суду [6]. Окрім того, обидві Сторони було закликано до утримання від дій, особливо військового характеру, що можуть призвести до порушення прав людини, закріплених у Європейській Конвенції з прав людини.

13 червня 2014 року Україна звернулась до ЄСПЛ у зв'язку із викраденням груп українських дітей-сиріт та дітей, які позбавлені батьківського піклування, та подальшим їх вивезенням до Російської Федерації. Подібні випадки трапились у червні, липні та серпні 2014 року. Завдяки дипломатичним зусиллям з боку України діти були поверненні до України. Після першого випадку викрадення українських дітей ЄСПЛ прийняв рішення про застосування Правила 39 Регламенту ЄСПЛ та зазначив, що Російська Федерація має поважати права людини, закріплені у Європейській конвенцій 3 прав людини, а також повернути групу дітей до України. У даному випадку 
Україна зазначала про порушення статті 2 Конвенції (право на життя), статті 3 Конвенції (заборона катування), стаття 5 (право на свободу та особисту недоторканість), стаття 8 (право на повагу до сімейного та приватного життя), а також на порушення статті 2 Протоколу №4 до Конвенції (свобода пересування).

Окрім того, Суд зазначив, що Російська Федерація повинна надати інформацію про обставини вивезення дітей на територію держави, а також проінформувати про порядок виконання тимчасового заходу. Тимчасовий захід було знято після переконання в тому, що зазначені особи повернулися до України.

9 липня 2014 року Україна звернулась до ЄСПЛ у зв'язку з поміщенням під варту до Сімферопольського СІЗО сина депутата Верховної Ради України Мустафи Джемільова. Окрім того, Мустафра Джемільов подав індивідуальну заяву до ЄСПЛ проти України та Російської Федерації. ЄСПЛ прийняв рішення застосувати Правило 39 Регламенту ЄСПЛ та зазначив, що Україна та Росія мають забезпечити дотримання прав Хайсера Джемільова, зокрема гарантувати повагу до його особистої безпеки та право на правову допомогу [7].

У зв'язку із інцидентом, який стався у Керченський протоці 25 листопада 2018 року, Україна подала міждержавну заяву до ЄСПЛ 29 листопада 2018 року. 4 грудня 2018 року Європейський Суд з прав людини прийняв рішення про застосування Правила 39 Регламенту Суду та зазначив, що відповідно до тимчасових заходів Російська Федерація повинна надати належну медичну допомогу для полонених українських моряків [8].

Висновок. Застосування Правила 39 Регламенту Європейського Суду 3 прав людини у міждержавних справах, як може здатися на перший погляд, відігріє ключову роль у випадку необхідності термінового реагування на порушення прав та свобод людини, гарантованих Європейською Конвенцією 3 захисту прав людини. Однак, проблемним питанням залишається юридична сила рішень Європейського суду з прав людини щодо застосування тимчасових заходів. Оскільки ЄСПЛ не може примусити державу до обов'язкового виконання рішення про вжиття тимчасових заходів, застосування Правила 39 Регламенту Європейського суду з прав людини залишається на розсуд держави, а отже має рекомендаційний характер.

\section{Список використаних джерел:}

1. European Court of Human Rights. (2019). Overview 1959-2018 - European Court of Human Rights. Вилучено 3 https://www.echr.coe.int/Documents/Overview_19592018_ENG.pdf.

2. European Court of Human Rights. (2019). Analysis of statistics 2018. Вилучено 3 https://echr.coe.int/Documents/Stats_analysis_2018_ENG.pdf

3. Rules of Court. (2019). Вилучено з https://www.echr.coe.int/Documents/Rules_Court_ENG.pdf

4. Case of Mamatkulov and Askarov v. Turkey, Judgment of the European Court of Human Rights $\begin{array}{lllll}\text { of } & 4 & \text { February } & 2005 . & \text { Вилучено }\end{array}$ https://hudoc.echr.coe.int/eng\#\{\%22dmdocnumber\%22:[\%22717615\%22],\%22itemid\%22:[\%22 001-68183\%22]\}

5. Georgia v. Russia (II), Decision of the European Court of Human Rights of 13 December 2011. Вилучено 3 https://hudoc.echr.coe.int/eng\#\{\%22itemid\%22:[\%22001-108097\%22]\}

6. European Court of Human Rights. (2014). Interim measure granted in inter-State case brought by Ukraine against Russia. Вилучено $3 \mathrm{https} / / \mathrm{www} . c 0 e$. int/en/web/portal//interim-measuregranted-in-inter-state-case-brought-by-ukraine-against-russia 
7. Ukraine v. Russia, Decision of the European Court of Human Rights of 1 September 2015. Вилучено 3 https://hudoc.echr.coe.int/eng\#\{\%22itemid\%22:[\%22001-157568\%22]\}

8. European Court of Human Rights. (2018). ECHR grants interim measure in new inter-State case brought by Ukraine against Russia concerning events in the Kerch Strait. Вилучено 3 https://hudoc.echr.coe.int/app/conversion/pdf?library=ECHR\&id=003-62692358166102\&filename $=E C H R \% 20$ grants\%20Rule $\% 2039 \% 20$ in $\% 20$ new $\% 20$ interState $\% 20$ case $\% 20$ Ukraine $\% 20$ v. $\% 20$ Russia $\% 20$ concerning\%20vents $\% 20$ in $\% 20$ the $\% 20$ Kerch \%20Strait.pdf

\title{
ЗАСТОСУВАННЯ СТРОКІВ ЗВЕРНЕННЯ ДО СУДУ ПРИ ВИРІШЕННІ СПРАВИ СУДАМИ
}

\author{
Пархуць Владислав Дмитрович \\ студент 5 курсу юридичного фракультету \\ Дніпровський національний університет імені Олеся Гончара
}

НАУКОВИЙ КЕРІВНИК:

Забродіна Олена Валентинівна

кандидат політичних наук, доцент кафедри цивільного,

трудового та господарського права

Дніпровський національний університет імені Олеся Гончара

УКРАЇ̈А

Європейський суд з прав людини наголошує, що «позовна давність - це законне право правопорушника уникнути переслідування або притягнення до суду після закінчення певного періоду після скоєння правопорушення. Термін позовної давності, що є звичайним явищем у національних законодавствах держав - учасників Конвенції, виконує кілька завдань, в тому числі забезпечує юридичну визначеність та остаточність, запобігаючи порушенню прав відповідачів, які можуть трапитись у разі прийняття судом рішення на підставі доказів, що стали неповними через сплив часу» (п. 570 рішення від 20 вересня 2011 року за заявою № 14902/04 у справі ВАТ «Нафртова компанія «Юкос» проти Росії»; п. 51 рішення від 22 жовтня 1996 року за заявами № 22083/93, 22095/93 у справі «Стаббінгс та інші проти Сполученого Королівства»).»

Інститут строків позовної давності досліджували багато вчених, серед яких можна виділити О.В.Адрійчук, М.С.Шакарян, О.Р. Михайленко, В. І. Тертишніков, С. Я. Фурса, С. І. Чорнооченко, М. И. Штефан та інші.

Відповідно до п. 3 статті 267 Цивільного кодексу України позовна давність застосовується судом лише за заявою сторони у спорі, зробленою до винесення ним рішення [1].

Відповідно до п.4 статті 267 Цивільного кодексу України сплив позовної давності, про застосування якої заявлено стороною у спорі, $є$ підставою для відмови у позові [1].

Відповідно до постанов Верховного Суду України від 24.06.2015 № 6738цс15, від 18.03.2015 № 6-25цс15 без заяви сторони у спорі ні загальна, ні спеціальна позовна давність застосовуватися не може за жодних обставин, 
оскільки можливість застосування позовної давності пов'язана лише 3 наявністю про це заяви сторони.

Згідно із ч. 3 п. 11 Постанову Пленуму Верховного Суду України «Про судове рішення у цивільній справі» № 14 від 18.12.2009 встановивши, що строк для звернення з позовом пропущено без поважної причини, суд у рішенні зазначає про відмову в позові з цих підстав, якщо про застосування позовної давності заявлено стороною у спорі, зробленою до ухвалення ним рішення, крім випадків, коли позов не доведено, що є самостійною підставою для цього.

Тобто, з аналізу вищезазначених норм вбачається, що сторони спору можуть подавати заяви про застосування строків позовної давності лише під час розгляду справи судом першої інстанції, в той час як суд не має право застосовувати позовну давність за власною ініціативою.

Натомість, суди апеляційної інстанції відмовляють у прийнятті заяв про застосування строків позовної давності, оскільки рішення у справі вже було постановлено судом першої інстанції.

Але при цьому законодавством не встановлюється вимоги щодо форми заяви про сплив позовної давності.

Відповідно до пп. 3 ч.1 ст. 43 Цивільного процесуального кодексу України учасники справи мають право подавати заяви та клопотання, надавати пояснення суду, наводити свої доводи, міркування щодо питань, які виникають під час судового розгляду, і заперечення проти заяв, клопотань, доводів і міркувань інших осіб [2].

Верховний Суд України у постанові від 16 серпня 2017р. у справі № 62667 ц16 вказав, що заяву про сплив позовної давності може бути викладено у відзиві на позов або у вигляді окремого клопотання - письмового чи усного, що відповідає вимогам наведених статей процесуального законодавства.

Тобто, заяву про сплив позовної давності може бути подана в різних формах:

1) у вигляді клопотання;

2) у відзиві чи запереченнях;

3) усно під час розгляду справи [3].

Однак, існують випадки, коли суд апеляційної та касаційної інстанції може звернути увагу на доводи скаржника щодо застосування строків позовної давності. Подібна ситуація може виникнути під час перегляду заочного рішення суду, коли відповідач з об'єктивних причин не міг скористатись правом подання заяви про застосування позовної давності. Наприклад, якщо відповідача не було належним чином повідомлено про місце та час розгляду [4].

Велика Палата Верховного суду у постанові у справі№ 200/11343/14-ц від 17.04.2018 вказує, що той факт, що відповідач, який не був належно повідомлений судом першої інстанції про час і місце розгляду справи, не брав участі у такому розгляді, є підставою для розгляду апеляційним судом заяви цього відповідача про застосування позовної давності, навіть якщо така заява не подавалася у суді першої інстанції.

Отже, наявність в законодавстві чітких строків звернення до суду є однією з умов реалізації права на справедливий судовий розгляд, що гарантовано Конвенцією про захист прав людини й основоположних свобод.

Список використаних джерел: 
1. Цивільний кодекс України (2003). Вилучено з https://zakon.rada.gov.ua/laws/card/435-15.

2. Цивільний процесуальний кодекс України (2004). Вилучено 3 https://zakon.rada.gov.ua/laws/show/1618-15\#n228.

3. Круглова О.О. (2017). Курс лекцій з дисципліни «Цивільне право». Київ: Видавець Біла К.О.

4. Матвійчук В.К. \& Тімуш І.С. (2013). Цивільне право України (у запитаннях та відповідях): Навчальний посібник : Практикум. Київ: ВН3 «Національна академія управління».

\title{
ІНФОРМАЦІЙНІ РЕСУРСИ ЯК КРИТИЧНО ВАЖЛИВА ІНФРАСТУКТУРА: ОКРЕМІ ПИТАННЯ ПРАВОВОГО РЕГУЛЮВАННЯ
}

\begin{abstract}
Козирчук Іван Вікторович
курсант 4 курсу, 2 групи Інституту підготовки юридичних кадрів для СБ України Національного юридичного університету імені Ярослава Мудрого
\end{abstract}

УKPAÏHA

Зважаючи на об'єктивну неможливість забезпечити абсолютний захист і безпеку всіх інфраструктурних систем, в більшості країн світу імплементується концепція критичної інфраструктури, що дозволяє виділити і сконцентрувати увагу на системах, мережах та окремих об'єктах, знищення яких матиме серйозні негативні наслідки для національної безпеки країни та суспільства в цілому.

Сучасне суспільство, його безпека значною мірою залежить від інформаційно-комунікаційних систем і мереж, відмова (або пошкодження) яких може призвести до хаосу, величезних фінансових збитків і навіть до масової загибелі людей. Як приклад, вірус Реtya.А, модифікована версії вірусу "Wannacry", який 27 червня 2017 року «атакував» Україну і за лічені години розлетівся країною, залишивши багато державних та приватних компаній без роботи. Розсилка листів з вірусом переважно відбувалась на корпоративні електронні скриньки, але були випадки «зараження» і приватних комп'ютерів [1]. Вважається, що це була найбільша в українській історії «хакерська» атака. Крім України, даний вірус вразив комп'ютерні мережі компаній у більш ніж 60 країнах світу. Але, на жаль, це не поодинокий приклад. Зокрема, як свідчать результати дослідження "2009 Managed Security in the Enterprises» 98\% організацій США зазнали матеріальних втрат від хакерських атак, їм стало значно складніше забезпечувати IT- безпеку [2].

Враховуючи на ці та інші небезпеки, у переважній більшості країн світу інформаційні ресурси визначаються як критично важливий елемент інфраструктури. Відповідно до існуючих підходів до критичної інформаційної інфраструктури належать такі об'єкти інформаційної інфраструктури: державні електронні інформаційні ресурси, електронні інформаційні ресурси, де обробляється (зберігається) інформація що $є$ власністю держави, або інформація, несанкціоновані дії щодо якої може створювати загрозу 
національній безпеці та обороноздатності країни; автоматизовані системи управління, що використовуються суб'єктами Воєнної організації держави; телекомунікаційні системи загального користування; спеціальні телекомунікаційні системи; автоматизовані системи управління, що здійснюють керування виробничими та (або) технологічними процесами на об'єктах підвищеної небезпеки; інформаційно-телекомунікаційні системи та автоматизовані системи управління, несанкціоноване втручання в роботу яких може загрожувати економічній, фінансовій, соціальній безпеці або завдати шкоди міжнародному іміджу держави.

В Україні прийнято цілу низку нормативно-правових актів, які закріплюють i регулюють використання, класифрікацію, функції, перелік інфрормаційних ресурсів як критично важливої інфрраструктури. Це Закони України «Про Основи національної безпеки України», «Про інформацію», «Про державну таємницю», «Про захист інформації в інформаційно-телекомунікаційних системах», «Про боротьбу з тероризмом», міжнародні договори, ратифіковані Верховною Радою України, акти Президента України (передусім, «Стратегія національної безпеки України» та «Доктрина інформаційної безпеки України») та Кабінету Міністрів, а також і інші нормативно-правові акти.

У сучасному суспільстві практично всі інфраструктури, які забезпечують його життєдіяльність, використовують інформаційні технології, які, у свою чергу, відіграють критичну роль практично в будь-якій інфрраструктурі. Враховуючи це, Кабінетом Міністрів України 23 серпня 2016 року було прийнято Постанову «Про затвердження Порядку формування переліку інформаційно-телекомунікаційних систем об'єктів критичної інфрраструктури держави». Згідно цієї постанови включені до переліку інформаційнотелекомунікаційні системи об'єктів критичної інфрраструктури є критичною інформаційною інфраструктурою держави, що захищається від кібератак у першу чергу (пріоритетно) [3].

Безсумнівного значення має Закон України «Про основні засади забезпечення кібербезпеки України», прийнятий Верховною Радою України 05 жовтня 2017 року. У Законі отримали закріплення такі важливі терміни, як: інцидент кібербезпеки, кібератака, кібертероризм, критично важливі об'єкти інфрраструктури, критична інформаційна інфрраструктура, об'єкт критичної інформаційної інфраструктури та інші. Щодо останніх термінів, то критична інформаційна інфраструктура розглядається як сукупність об'єктів критичної інформаційної інфраструктури. А об'єкти критичної інформаційної інфраструктури - це, у свою чергу, комунікаційна або технологічна система об’єкта критичної інфрраструктури, кібератака на яку безпосередньо вплине на стале функціонування такого об'єкта критичної інфрраструктури. Згідно даного Закону до об'єктів критичної інфрраструктури можуть бути віднесені підприємства, установи та організації незалежно від фрорми власності, які: 1) провадять діяльність та надають послуги в галузях енергетики, хімічної промисловості, транспорту, інформаційно-комунікаційних технологій, електронних комунікацій, у банківському та фінансовому секторі; 2) надають послуги у сфрерах життєзабезпечення населення, зокрема у сферах централізованого водопостачання, водовідведення, постачання електричної енергії і газу, виробництва продуктів харчування, сільського господарства, 
охорони здоров'я; 3) є комунальними, аварійними та рятувальними службами, службами екстреної допомоги населенню; 4) включені до переліку підприємств, що мають стратегічне значення для економіки і безпеки держави; 5) є об'єктами потенційно небезпечних технологій і виробництв[4].

Необхідність забезпечення належного стану захищеності об'єктів критичної інфраструктури, інформаційної безпеки піднімає на новий рівень проблему державно-приватного партнерства у сфері безпеки, у тому числі інформаційної безпеки, визначення організаційних та правових засад такого партнерства. Особливо враховуючи той фракт, що значна кількість об'єктів критичної інфраструктури знаходиться у приватній власності.

За сучасних умов у різних країнах світу вже задіяні ефективні системи атестації, сертифікації та ліцензування окремих об'єктів і засобів забезпечення інформаційної безпеки. В той же час, на даному етапі практично відсутні універсальні механізми міжнародно-правового регулювання критичних інформаційних інфрраструктур. Втім, чимало законодавчих розробок ведеться на національному рівні. Активно обговорюється концепція критичної інформаційної інфраструктури в міжнародно-правовій доктрині. Отже, актуальним завданням сьогодення $є$ посилення міжнародного співробітництва з напрямку, що розглядається.

\section{Список використаних джерел:}

1. Людмила Голоднік, Дмитро Мороз, Наталя Жижко, "5 канал" Наймасштабніша кібератака в історії України; 27.06.2017 // Вилучено 3 https://www.5.ua/suspilstvo/naimasshtabnishakiberataka-v-istorii-ukrainy-shcho-vidomo-siuzhet-149003.html

2. Матюхіна Н.П.(2013). Приватний сектор безпеки США: шляхи розвитку та реалії сьогодення: монографія: Юрайт, 2013.

3. Про затвердження Порядку формування переліку інформаційно-телекомунікаційних систем об'єктів критичної інфраструктури; Постанова Кабінету Міністрів України від 23.08.2016 № 563 // Вилучено 3 http://zakon5.rada.gov.ua/laws/show/563-2016-\%D0\%BF

4. Про основні засади забезпечення кібербезпеки України; 05.10.2017 № 2163-19 // Вилучено $3 \mathrm{http}: / / z a k o n 3 . r a d a . g o v . u a / l a w s /$ show/2163-19. 


\section{МОЖЛИВІСТЬ ВІДТВОРЕННЯ ЕЛЕКТРОННИМ КОНОСАМЕНТОМ ФУНКЦІЙ ПАПЕРОВОГО: МІЖНАРОДНО- ПРАВОВИЙ АСПЕКТ}

Ткач Олександр Олександрович

здобувач вищої освіти Навчально-наукового інституту «Юридичний інститут» ДВНЗ «Київський національний економічний університет імені В. Гетьмана»

НАУКОВИЙ КЕРІВНИК:

Мамчур Людмила Володимирівна

канд. юрид. наук, доцент, доцент кафедри цивільного та

кримінального права і процесу юридичного фракультету

Чорноморський національний університет імені Петра Могили

УКРAÏHA

Ідея використання електронного коносамента як альтернативи традиційному паперовому обумовлена рядом чинників. Серед них слід відмітити: простій вантажу внаслідок невчасного отримання коносамента, вірогідність втрати коносамента на шляху слідування, ризик підроблення тощо. Міжнародними організаціями було прийнято ряд нормативно-правових актів, направлених на врегулювання обігу нової фрорми коносамента. Проте, чи може вона відтворити функції класичної потребує встановлення.

Відповідно до Гамбурзьких правил 1978 р., коносаментом є документ, що підтверджує договір морського перевезення та отримання чи завантаження вантажу перевізником, у відповідності до якого перевізник зобов'язаний здати вантаж в обмін на пред'явлення такого документа [1]. У правилах Інкотермс визначені три важливі функції, які виконує коносамент: доказ поставки товару на борт судна; доказ укладення договору перевезення; засіб передання прав на товар у дорозі іншій стороні шляхом передачі їй паперового документа [2]. Для того, щоб е-коносамент міг прийматися замість паперового, перелічені функції мають бути відтворені в електронному форматі.

3 кінця XX століття в світі робились спроби прирівняння електронних товаророзпорядчих документів до паперових. У версії Інкотермс 1990 року почала допускатись заміна паперових документів електронними повідомленнями за умови, що сторони домовилися підтримувати зв'язок в електронній формі [2]. Також було прийнято ряд нормативно-правових актів: Правила Міжнародного морського комітету для електронних коносаментів (1990 рік), Типовий закон ЮНСІТРАЛ про електронну торгівлю (1996 рік), Типовий закон ЮНСІТРАЛ про електронні підписи (2001 рік), Конвенція ООН про використання електронних повідомлень у міжнародних договорах (2005 рік), Роттердамські правила (2008 рік), Типовий закон ЮНСІТРАЛ про електронні передавальні записи (2017 рік).

Правила Міжнародного морського комітету для електронних коносаментів (1990 року) мають рекомендаційний характер, тобто діють лише у випадку визнання їх положень державою. В них передбачається, що сторони погоджуються не заявляти заперечень проти того що договір перевезення або супровідні документи не мають матеріальної форми. Тобто, коносамент, що був виданий в електронній фрормі та за змістом відповідає нормам національного законодавства, автоматично прирівнюється до письмового 
(паперового), якщо сторонами погоджено використання Правил 1990 року. Хоча Правила не стали широко застосовуватись на практиці, їх положення заклали основу обігу е-коносаменту, а саме те, що інформація, яка міститься в електронному документі, має таку ж саму силу, як і паперовий документ [3].

Типовий закон про електронну торгівлю 1996 року, як і Правила 1990 року, має рекомендаційний характер, але на відміну від Правил застосовується набагато ширше, за останніми даними у 71 країні. Правова природа Типового закону 1996 року полягає в тому, що він розроблений Комісією ООН з прав міжнародної торгівлі (ЮНСІТРАЛ) як модельний нормативний акт, тобто для того, щоб держави могли брати його за основу при розробленні й прийнятті національного законодавства. Тому у Типового закону не може бути сторін чи учасників, а можуть бути лише держави, що прийняли національний закон на основі типового. Такі закони були прийняті у деяких штатах Канади та США, Австралії, В'єтнамі, Мексиці, ОАЕ, ПАР, Сингапурі та інших державах [4].

Даний акт закріплює в собі основні елементи сучасного права електронної торгівлі - це принципи недискримінації, технологічної нейтральності та функціональної еквівалентності. Принцип недискримінації гарантує те, що документ не буде позбавлений юридичної сили, дійсності чи позовної сили лише на підставі того, що він складений в електронній формі. Принцип технологічної нейтральності припускає прийняття положень, які являються нейтральними по відношенню до використовуваної технології. Це означає, що, враховуючи швидкі темпи технологічного прогресу, норми закону не прив'язані до конкретної технології, таким чином розраховані на те, щоб дозволити використання майбутніх технологічних розробок без внесення додаткових змін. Принцип функціональної еквівалентності встановлює критерії, за якими електронні повідомлення можуть бути розглянуті як еквівалент повідомлень в паперовому вигляді.

Стаття 17 Закону встановлює функціональний еквівалент паперового документа стосовно передачі прав і обов'язків шляхом передачі електронних даних. Відповідно до правил даного акту електронний документ може бути повідомленням в фрорматі pdf, jpeg або іншому схожому фрорматі. Найголовнішим є забезпечення формальним вимогам, а саме можливості прочитати, продемонструвати та використовувати в подальшому. До такого файлу також може додаватися електронний індосамент, що підтверджує передачу прав на електронний документ [5].

Малюков К.А., опираючись на зміст Типового закону, дійшов висновку, що електронний транспортний документ може виконувати всі функції документа на паперовому носії і прирівнюватись до нього в правовому статусі [6, с. 130].

Конвенція ООН про договори повністю або частково морського міжнародного перевезення вантажів 2008 р. або Роттердамські правила також включають положення щодо правового статусу е-коносаменту i, порівняно 3 іншими актами могли б мати універсальний характер. Але документ досі не набув чинності у зв'язку з недостатньою кількістю ратифрікацій державами.

Перелічені нормативні акти передбачають можливість обміну даними шляхом надсилання EDI-повідомлень (англ. Electronic Data Intercharge - обмін електронними даними), як вже було вказано, за умови, що сторони заздалегідь про це домовились. У такий спосіб повідомлення можуть передаватись як безпосередньо між сторонами, так і шляхом залучення третьої особи, що надає такі послуги. 
Висновки. Отже, сучасний коносамент може виражатися як у класичній паперовій, так і у електронній формі. Для класичної форми типовим $є$ виконання трьох функцій: доказ поставки товару на борт судна, доказ укладення договору перевезення, засіб передання прав на товар у дорозі іншій стороні. Аналіз Типового закону ЮНСІТРАЛ дає підстави стверджувати про можливість відтворення е-коносаментом функцій класичного. Однак, важливо відмітити, що е-коносамент матиме легальний статус лише в тих юрисдикціях, де норми Типового закону імплементовані в національне законодавство або ж у випадку вибору іншої юрисдикції за принципом автономії волі.

\section{Список використаних джерел:}

1. Конвенція Організації Об'єднаних Націй про морське перевезення вантажів 1978 року (Гамбурзькі правила). zakon.rada.gov.ua. Вилучено 3: https://zakon.rada.gov.ua/laws/ show/995_391

2. Інкотермс Офіційні правила тлумачення торговельних термінів Міжнародної торгової палати (редакція 2000 року) (укр./poc.). zakon.rada.gov.ua. Вилучено 3: https://zakon.rada.gov.ua/laws/show/988_007

3. Rules for Electronic Bills of Lading. comitemaritime.org . Retrieved from https://comitemaritime.org/work/rules-for-electronic-billing-of-lading/

4. Типовой закон ЮНСИТРАЛ об электронной торговле (1996 год). uncitral.org. Вилучено з: http://www.uncitral.org/uncitral/ru/uncitral_texts/ electronic_commerce/1996Model_status.html

5. Типовой закон ЮНСИТРАЛ об электронной торговле (1996 год) с дополнительной статьей 5 bis, принятой в 1998 году. uncitral.org. Вилучено 3: http://www.uncitral.org/uncitral/ru/uncitral_texts/electroniccom merce/1996 Model.html

6. Малюков, К.А. (2017) Основные направления развития правил о договоре морской перевозки груза. Дисс. на соискание ученой степени кандид. юр. наук. Москва: Федеральное государственное бюджетное образовательное учреждение высшего образования «Всероссийская академия внешней торговли Министерства экономического развития Российской Федерации».

\section{НАЛЕЖНИЙ РІВЕНЬ ПРАВОВОЇ ДОПОМОГИ ЯК ГАРАНТІЯ ПРАВА НА ЗАХИСТ}

Кулинич Аліна Юріївна здобувач вищої освіти

Полтавський юридичний інститут Національного юридичного університету імені Ярослава Мудрого УКРАЇHA

Одним із головних обов'язків демократичних держав $є$ забезпечення прав людини. Конвенція про захист прав людини та основоположних свобод у п. 3 ст. 6 та Конституція України у ст. 59 серед основоположних прав і свобод визнають право на професійну правничу допомогу. Щодо кримінального провадження можемо говорити про необхідність забезпечення права на захист, складовою якого є участь захисника. Для повної і всебічної реалізації цих прав підозрюваному, обвинуваченому, засудженому, виправданому має бути забезпечений належний рівень правової допомоги. Тому, з огляду на 
невелику кількість наукових робіт з цього приводу, необхідно дослідити у чому виявляється належний рівень правової допомоги та можливі наслідки його відсутності.

Основним критерієм визначення належного рівня правової допомоги $€$ компетентність захисника, під якою деякі науковці розуміють наявність необхідної правової кваліфікації для надання захисту у певному кримінальному провадженні [1]. Тобто, йдеться саме про знання особи. Такі науковці як А.Р. Фонарьов, $€$.О. Климов пропонують визначати компетентність як професійну готовність, професіоналізм, але детального тлумачення не надають [2]. Тому пропоную під компетентністю захисника розуміти наявність достатніх знань, навиків, досвіду, психологічних якостей, використання яких забезпечить ефективний захист прав, свобод та інтересів підзахисного. У доктрині до складових компетентності адвокатів відносять мотиваційно-цільовий, когнітивний, соціальний, аксіологічний та аутопсихологічний аспекти [3]. Безумовно лише наявність всіх цих сфрормованих елементів свідчить про належну кваліфікацію адвоката, але, на мою думку, найголовнішим $€$ когнітивний, який і передбачає наявність накопичених знань та уміння професійно їх використовувати.

Можна відзначити, що стосовно належного рівня правової допомоги існує певна презумпція. Відповідно до ст. 45 КПК України захисником $є$ адвокат [4]. А тому до нього висувається ряд вимог, серед яких стаття 6 Закону України «Про адвокатуру та адвокатську діяльність» визначає: повну вищу юридичну освіту, стажування, складення кваліфікаційного іспиту, чим особа доводить, що має відповідний рівень знань тощо [5]. Тобто, адвокат повинен бути не лише обізнаним у своїй сфері, мати професійну підготовку, а й досвід, тобто практичне застосування своєї освіченості у цій сфері. Крім вимог, визначених у вищезазначеному законі, дослідники також звертають увагу і на інші якості, якими має бути наділений адвокат. Серед основних вирізняють: здатність знаходити підхід у спілкуванні як з підзахисним, так і з іншими особами, самоосвіта, самодисципліна, вміння швидко реагувати на нові обставини та приймати вольові рішення [2]. Тому вважається, що адвокат, отримавши свідоцтво про право на заняття адвокатською діяльністю, $є$ кваліфрікованим, відповідно і захист він здійснює на належному рівні.

Варто відзначити, що попри наявність свідоцтва про право на заняття адвокатською діяльністю, правова допомога все ж може бути некваліфрікованою, неефективною. Тому КПК України у п. 4 ч. 4 ст. 47 закріплює право захисника відмовитись від надання правової допомоги у зв'язку 3 відсутністю належної кваліфікації, необхідної для даного провадження [4]. Дослідники зауважують, що необхідно було б закріпити це не як право адвоката, а як його обов'язок [1]. Оскільки за наявності сумнівів у захисника щодо власних знань, вирішення питання про подальше здійснення захисту покладається на його розсуд, що в окремих випадках може призвести до надання правової допомоги неналежного рівня, а тому не буде повною мірою реалізовано право на захист. Наприклад, Апеляційний суд Закарпатської області ухвалою від 23 квітня 2013 року №712/1-242/11 встановив, що засуджений вказує на порушення його права на захист, оскільки призначений захисник неналежно виконував свої обов'язки, так як під час досудового розслідування не брав у ньому активної участі, а у судових дебатах фрактично зайняв позицію обвинувачення, при цьому допомоги у поданні апеляційної 
скарги не надавав. Тому суд визнав, що мало місце неналежне надання правової допомоги, що призвело до неефективного захисту. Відповідно було порушено п.П. «с» п.3 ст. 6 Конвенції про захист прав людини і основоположних свобод», чим було створено перешкоди суду постановити законний, обґрунтований та справедливий вирок [6].

Чинний КПК у ст. 78 передбачає підстави відводу захисника, але відсутність належної компетентності серед цих підстав немає [4]. Колегія суддів Тернопільського міськрайонного суду Тернопільської області ухвалою від 25 вересня 2018 року у справі №601/2038/16-к встановила, що обвинувачений заявив відвід захиснику через те, що останній не в повному обсязі виконує свої обов'язки. Суд звернув увагу на узагальнення ВССУ «Про судову практику забезпечення права на захист у кримінальному провадженні» від 25.09.2015 року, вказавши, що ефективний захист і вільний вибір захисника є елементами права на захист. Використання практики ЄСПЛ забезпечить реалізацію цього права. Зокрема, у п. 262 рішення ЄСПЛ від 21 квітня 2011 року у справі «Нечипорук і Йонкало проти України», визначено, що право на ефективний захист це одна з головних ознак справедливого судочинства. Тому суд задовольнив заяву на підставі ст. 54 КПК України як відмову від захисника [7].

Отже, належний рівень правової допомоги забезпечує реалізацію права особи на захист і передбачає наявність компетентного захисника, який ефрективно використовує у конкретному кримінальному провадженні надані йому права. Для запобігання порушення права на професійну правничу допомогу через некомпетентність захисника, що може проявлятися у неефективному захисті чи «символічному характері» послуг, КПК України передбачає можливість адвоката заявити самовідвід з цієї причини або ж підзахисному замінити чи відмовитись від захисника.

\section{Список використаних джерел:}

1. Торбас, О.О. Наслідки встановлення некомпетентності захисника. Актуальні проблеми удосконалення кримінального процесуального законодавства: матеріали Всеукраїнської науково-практичної конфреренції, присвячено до 70-річчя д. ю. н., профресора Ю.П. Аленіна (с. 126-128). 21 квітня, 2017, Одеса, Україна: Юрид. л-ра

2. Зошій, І . В. (2015). Професіоналізм та професійна компетентність юристів як об'єкт наукових досліджень. Науковий вісник Херсонського державного університету. (5), 101-105.

3. Івашкевич, І. В. (2016). Специфіка професійної діяльності юриста та структура його професійної компетенції. Збірник наукових праць РДГУ. (7), 80-83.

4. Кримінальний процесуальний кодекс України. № 4651-VI. (2012). Вилучено з: https://zakon.rada.gov.ua/laws/show/4651-17.

5. Про адвокатуру та адвокатську діяльність (Закон України). № 5076-VI. (2012). Вилучено 3: https://zakon.rada.gov.ua/laws/show/5076-17.

6. Ухвала Апеляційного суду Закарпатскої області. №712/1-242/11. (2013). Вилучено з: http://www.reyestr.court.gov.ua/Review/31382959.

7. Ухвала Колегії суддів Тернопільського міськрайонного суду Тернопільської області. №601/2038/16-к. (2018). Вилучено 3: http://www.reyestr.court.gov.ua/Review/76793335. 


\title{
ОСОБЛИВОСТІ РОЗВИТКУ АВІАЦІЙНОЇ ПРОМИСЛОВОСТІ В УКРАÏНІ ТА ÏI ГОСПОДАРСЬКО-ПРАВОВЕ ЗАБЕЗПЕЧЕННЯ
}

\author{
Оленюк Анастасія Андріївна \\ студентка Юридичного фракультету \\ Національний авіаційний університет
}

НАУКОВИЙ КЕРІВНИК:

Поліщук Інна Володимирівна

старший викладач кафедри господарського, повітряного та космічного права Національний авіаційний університет

УКPÄ̈HA

Успішний розвиток будь-якої країни в XXI ст. $є$ неможливим без прогресу в технологічно складних галузях промисловості, які $€$ справжнім локомотивом для економіки загалом. Однією з таких технологічно складних, економічно вигідних й політично престижних галузей є авіаційна промисловість.

На сьогодні авіаційна промисловість в Україні має надзвичайно великий потенціал для подальшого розвитку, але для цього їй необхідно, перш за все, подолати ряд першочергових проблем. Безумовно, причини подібного стану речей та перспективи виходу з кризи ще потребують вивчення й аналізу фахівцями з економіки, теорії управління, політології, але для глибокого розуміння сучасних проблем і пошуку шляхів їх вирішення необхідно всебічно проаналізувати історію розвитку підприємств цього комплексу, формування його структури й спеціалізації.

Українська авіаційна промисловість має давню історію і пройшла у своєму розвитку кілька етапів, причому найдовший - аж до кінця 1991 р. - тривав не за умов суверенної держави, а за імперських (союзних) часів авіаційнопромислового комплексу. Саме тоді було закладено основи української авіаційної промисловості, ії̈ виробничої й дослідно-конструкторської бази. Яскравим прикладом наявного потенціалу галузі може бути хоча б той фракт, що перший в СНД літак, спроектований і впроваджений у серійне виробництво після розпаду СРСР, був створений саме в Україні. Ним став регіональний пасажирський літак Ан-140 [1].

Також безумовним позитивом є свідчення про те, що Україна входить до елітної дев'ятки країн, які мають замкнутий технологічний цикл створення і виробництва авіатехніки. Крім проектування і виробництва пасажирських і транспортних літаків, в Україні $є$ мережа авіаремонтних підприємств, в тому числі і для відновлення бойових літаків і вертольотів.

Специфріка асортименту продукції українських авіазаводів, що історично склалася, виявляється в тому, що профільною продукцією для українських підприємств залишаються транспортні, а також пасажирські літаки для регіональних і середніх магістральних ліній. Це дозволяє українським виробникам розійтися по різних ринкових нішах з найбільшими світовими виробниками літаків. Однак саме ніша магістральних пасажирських лайнерів звичайно вважається найприбутковішою. 
Авіаційна промисловість $є$ одним із пріоритетних напрямів розвитку сучасної української економіки, тому необхідна державна підтримка галузі, яка, слід сказати, на сьогодні все ж $є$ недостатньою.

Господарське законодавство, зокрема ГКУ, встановлює основні господарсько-правові засоби впливу держави на діяльність суб'єктів господарювання. Універсальною правовою формою впливу держави на економічні відносини згідно з ГКУ $€$ формування стратегії і тактики її економічної політики [2].

$\mathrm{Ha}$ сьогодні державна підтримка літакобудівної промисловості здійснюється відповідно до положень Закону України «Про розвиток літакобудівної промисловості». Проте для того, аби бути успішним конкурентом на світовому ринку, названих заходів не завжди достатньо. Державна підтримка мусить мати систематичний характер і першим кроком у законодавчих зусиллях має стати створення ефективного комплексного i повного нормативно-правового забезпечення галузі, комплексної програми.

3 виникненням нагальної потреби у прийнятті нової Державної комплексної програми розвитку авіаційної промисловості України, була схвалена Стратегія розвитку вітчизняної авіаційної промисловості на період до 2020 року.

3 метою подолання кризового становища в авіаційному секторі України потрібно створювати сприятливі умови для вітчизняного суб'єкта господарювання, активізуючи світовий досвід інтегрування компаній авіаційної галузі в єдину систему. Перші спроби кардинально змінити систему авіапрому були зроблені у 2005 р. Було створено державну літакобудівну корпорацію «Національне об'єднання «Антонов». Наступним кроком у переформуванні авіапрому стало створення у 2007 р. державного авіабудівного концерну «Авіація України», що, на жаль, призвело до припинення серійного виробництва літаків. Далі у жовтні 2008 р. державний авіабудівний концерн «Авіація України» перейменовують у Державний авіабудівний концерн «Антонов» [3].

Отже, на сьогодні стан законодавчого регулювання авіаційної промисловості в Україні важко назвати оптимальним, адже ця галузь має ряд невирішених проблем, однією з яких є питання грамотного об'єднання підприємств літакобудівної промисловості.

\section{Список використаних джерел:}

1. Харук, А.А. (2010) Нарис історії авіаційної промисловості України (1910-ті - 1980-ті рр.). Львів: Видавництво Львівської політехніки.

2. Господарський кодекс України. № 436-IV. (2003). Вилучено з http://zakon3.rada.gov.ua/laws/ 436-15.

3. Бронова Ю. Г. (2012) Сучасний стан господарсько-правового забезпечення розвитку літакобудування в Україні Вісник Національної юридичної академії України імені Ярослава Мудрого, (8), 165-174. 


\title{
ОСОБЛИВОСТІ РОЗВИТКУ КРИМІНАЛЬНОГО ЗАКОНОДАВСТВА У ЧАСТИНІ РЕГУЛЮВАННЯ ВІДПОВІДАЛЬНОСТІ ЗА БЕЗДІЯЛЬНІСТЬ ВІЙСЬКОВОЇ ВЛАДИ 3 ЧАСІВ ЛИТОВСЬКИХ СТАТУТІВ І ДО СЬОГОДЕННЯ
}

\author{
Надоєв Артур Автонділович \\ аспірант кафедри кримінально правових дисциплін \\ Харківський національний педагогічний університет імені Г. С. Сковороди
}

УКРАЇНA

Процес розбудови та діяльності військової сили держави зіштовхується 3 певними негативними явищами, обумовленими різними чинниками серед яких й людський фрактор. 3 метою унеможливлення впливу негативного людського фрактору на процеси розбудови та діяльності орган законодавчої влади видає відповідні норми-заборони. Однією з таких норм-заборон $€$ кримінальноправова норма щодо відповідальності за бездіяльність військової влади. Ця норма має глибоке історичне коріння. Аналіз відповідної нормативно-правової, а також науково-теоретичної бази дає підстави стверджувати, що у різні часи робилися численні спроби боротьби з негативним явищем бездіяльності військової влади. Втім, попри значний досвід становлення, законодавчі норми, що регулюють відповідальність у сфері бездіяльності військової влади все ще далекі від ідеалу. Все це вказує, що досліджувана тема була, є, та буде актуальною доти доки існуватиме військо та військове керівництво (військова влада).

Вищевикладене обумовлює необхідність вивчення історичного аспекту законодавства у сфері бездіяльності військової влади з огляду на те, що подальше його успішне реформування видається не можливим без дослідження історичного досвіду. Переходячи до безпосередньо вивчення теми, насамперед, зауважимо, що важливе значення у контексті становлення законодавства у сфері бездіяльності військової влади мають Литовські Статути. Так, Артикул 5 । Литовського Статуту 1529 р. [8] покладає відповідальність на хорунжого, як на начальницьку особу у випадку, якщо він неправдиво свідчив гетьману про хворобу підлеглої людини, за умови, що потім це було доведено в суді. У цьому випадку хорунжий втрачає своє майно. У свою чергу, в Артикулі 8 прямо вказуються межі прав Гетьманів щодо перепису війська та заборону отримувати за коня більше встановленого, а при розпуску війська загалом щось отримувати. Артикул 14 розглядає певний вид відповідальності шляхтича, як військової владної особи.

II Литовський статут 1554 р. (набрав чинності 1566 р) [2] впроваджував нові норми-заборони у військово-кримінальній сфрері. Зокрема, вперше з'явилася заборона торгівлі зброєю з ворогом. Хоча такі нововведення не вплинули на розмаїття видів відповідальності військової влади, яка викладена у першому статуті.

III Литовським статутом 1588 р. [10] запроваджуються норми-заборони щодо пияцтва, ґвалтування інших військових злочинів. 
В цілому, аналізуючи Литовсько-польську добу можна зазначити, що це був прогресивний прорив у розбудові нормативної бази з питань відповідальності військової влади.

Будівництво радянського військово-кримінального законодавства розпочинається з 1920 року [1]. Тогочасне законодавство не містило статті окремо присвяченої бездіяльності військової влади.

Відсутня відповідна стаття й у КК РСФСР 1922 року [14], який продовжив розбудову досліджуваної норми у фокусі вимог, які склалися на той час. Кримінальну відповідальність за злочин «бездіяльність військової влади», який наразі кваліфікується за окремою статтею у КК РСФСР 1922 року було закріплено у ст.209, що встановлювала відповідальність й за перевищення військовим начальником меж своєї влади. Зокрема, відповідно до ч.1 ст.209 КК РСФСР 1922 року перевищення військовим начальником меж своєї влади або бездіяльність його, здійснена без злого умислу, що не призвели до дезорганізації довірених йому збройних сил і матеріальних засобів або інших особливо важливих наслідків, карається позбавленням волі на строк до трьох років з суворою ізоляцією.

У свою чергу, згідно ч. 2 цієї статті, перевищення військовим начальником меж своєї влади або бездіяльність його, здійснена без злого умислу, що не призвели до дезорганізації довірених йому збройних сил і матеріальних засобів, або військовий бунт, або відсутність належного постачання, або інші особливо важливі наслідки, карається позбавленням волі на строк до п'яти 3 суворою ізоляцією .

Водночас перевищення військовим начальником своєї влади або бездіяльність його скоєна зі злим умислом, або з користю чи з іншою метою, незалежно від того було спричинено чи ні наслідки [9], зазначені у даній статті, каралось позбавленням волі на строк не нижче п'яти років [11].

У кримінальних кодексах редакції 1926 року [7] та 1936 року [12] не відбулось істотних змін, щодо досліджуваної норми. Таких висновків можна дійти на підставі аналізу відповідних законодавчих положень цих кодексів.

Дещо прогресивніше дане питання було врегульовано у КК 1960 року. Однак, хоча в особливій частині Кримінального кодексу редакції 1960 року досліджувана норма була викладена дещо структурно, вона все ще не отримала повної самостійності. Так, згідно ст. 260 Зловживання владою. Перевищення або бездіяльність влади,

«а) Зловживання начальником або посадовою особою владою або службовим положенням, перевищення влади або службовими повноваженнями, бездіяльність влади, якщо ці діяння здійснювались систематично або через корисні спонукання або особистої зацікавленості, а рівно якщо вони причинили істотну шкоду - караються позбавленням волі на строк до п'яти років;

б) Ті самі діяння, якщо вони спричинили тяжкі наслідки - караються позбавленням волі на строк від трьох до десяти років;

в) Діяння, передбачені пунктами «а» і «б» цієї статті, вчинені у воєнний час або в бойовій обстановці - караються позбавленням волі на строк від п'яти до п'ятнадцяти років або смертною карою» [13].

Вагомим досягненням було кримінальне право України, в якому продовжувалося реформування відповідної норми. Величезним здобутком у кримінальному праві часів незалежності нашої держави став Кримінальний кодекс України, який прийнятий 5 квітня 2001 року та набув чинності 01 вересня 
2001 року. Адже саме у кодифікації кримінального законодавства 2001 року досліджувана норма вперше посіла самостійне місце. Відтепер кримінальна відповідальність за бездіяльність військової влади регулюється окремою статтею Кримінального кодексу України - ст. 426 «Бездіяльність військової влади» [6].

У даному контексті варто також зазначити про те, що нині чинна редакція ст.426 Кримінального кодексу України не $є$ початковою. Зокрема, неодноразово зазнавала змін ч.1 цієї статті. Йдеться про зміни внесені згідно Законів України «Про внесення змін до деяких законодавчих актів України у зв'язку з прийняттям Кримінального процесуального кодексу України» від 13.04.2012 р. № 4652-VI [4], «Про внесення змін до Кримінального кодексу України щодо посилення відповідальності за окремі військові злочини» від 12.02.2015 р. № 194-VIII [5], «Про внесення змін до деяких законодавчих актів України щодо посилення відповідальності військовослужбовців та деяких інших осіб» від 16.03.2017 р. № 1952-VIII [3].

Так, згідно Закону України «Про внесення змін до деяких законодавчих актів України у зв'язку з прийняттям Кримінального процесуального кодексу України» від 13.04.2012 р. № 4652-VI [4], абзац перший частини першої статті 426 було викладено в такій редакції: «1. Умисне неприпинення злочину, що вчиняється підлеглим, або ненаправлення військовою службовою особою до органу досудового розслідування повідомлення про підлеглого, який вчинив кримінальне правопорушення, а також інше умисне невиконання військовою службовою особою дій, які вона за своїми службовими обов'язками повинна була виконати, якщо це заподіяло істотну шкоду».

У свою чергу, згідно змін передбачених Законом України «Про внесення змін до Кримінального кодексу України щодо посилення відповідальності за окремі військові злочини» від 12.02.2015 р. № 194-VIII [5], ч.1 ст.426 було викладено в такій редакції: «1. Умисне неприпинення злочину, що вчиняється підлеглим, або ненаправлення військовою службовою особою до органу досудового розслідування повідомлення про підлеглого, який вчинив кримінальне правопорушення, а також інше умисне невиконання військовою службовою особою дій, які вона за своїми службовими обов'язками повинна була виконати, якщо це заподіяло істотну шкоду, - караються штрафом від п'ятдесяти до двохсот неоподатковуваних мінімумів доходів громадян або службовим обмеженням на строк до двох років, або позбавленням волі на строк до трьох років».

Згодом, у 2017 році відповідальність за бездіяльність військової влади зазнала змін у напрямку посилення відповідальності в частині розміру штрафу як виду покарання за цей злочин. Так, відповідно до Закону України «Про внесення змін до деяких законодавчих актів України щодо посилення відповідальності військовослужбовців та деяких інших осіб» від 16.03.2017 р. № 1952-VIII [3], «умисне неприпинення злочину, що вчиняється підлеглим, або ненаправлення військовою службовою особою до органу досудового розслідування повідомлення про підлеглого, який вчинив кримінальне правопорушення, а також інше умисне невиконання військовою службовою особою дій, які вона за своїми службовими обов'язками повинна була виконати, якщо це заподіяло істотну шкоду, - караються штрафом від трьохсот двадцяти п'яти до трьохсот вісімдесяти п'яти неоподатковуваних мінімумів доходів громадян або службовим обмеженням на строк до двох років, або позбавленням волі на строк до трьох років». 
Водночас слід вказати, що процес становлення законодавства України щодо кримінальної відповідальності за бездіяльність військової влади на сьогодні не можна вважати завершеним.

Підсумовуючи слід зазначити, що хоча врегулювання кримінальної відповідальності за бездіяльність військової влади в окремій статті Особливої частини Кримінального кодексу України, безперечно, є прогресивним кроком у розвитку законодавства у сфрері встановлення відповідальності за бездіяльність військової влади, інститут кримінальної відповідальності за вказаний злочин потребує подальшого реформування з метою удосконалення нині чинної редакції ст.426 Кримінального кодексу України.

Завдячуючи величезній та кропіткій праці вітчизняних науковців досліджувана норма не тільки посіла самостійне місце, але й почала охоплювати та висвітлювати більш широке коло суспільних відносин, які на теперішній час потребують більш глибокого аналізу та доопрацювання.

\section{Список використаних джерел:}

1. Герцензон, А. А. (1949). История советского уголовного права. Госюриздат.

2. Гайворонська, І. М. (2009). Примирення сторін кримінального конфрлікту за Литовськими статутами. Університетські наукові записки, (2), 24-27.

3. Про внесення змін до деяких законодавчих актів України щодо посилення відповідальності військовослужбовців та деяких інших осіб: Закон України від 16.03.2017 р. № 1952-VIII. URL: https://zakon.rada.gov.ua/ laws/card/1952-19 (дата звернення: 29.11.2019)

4. Про внесення змін до деяких законодавчих актів України у зв'язку з прийняттям Кримінального процесуального кодексу України: Закон України від 13.04.2012 p. № 4652-VI URL: https://zakon.rada.gov.ua/l aws/show/4652-17(дата звернення: 29.11.2019)

5. Про внесення змін до Кримінального кодексу України щодо посилення відповідальності за окремі військові злочини : Закон України від 12.02.2015 р. № 194-VIII. URL: https://zakon.rada.gov.ua/laws/card/194-19 (дата звернення: 29.11.2019)

6. Кримінальний кодекс України від 05.04.2001 p. № 2341-III. URL: https://zakon.rada.gov.ua/laws/card/2341-14 (дата звернення: 29.11.2019)

7. Михайленко, П. П. (1959). Нариси з історії кримінального законодавства Української РСР. К.: Вид-во Академії наук УРСР.

8. Перший (Старий) Статут Великого князівства Литовського 1529 p. URL: http://resource.history.org.ua/cgi-

bin/eiu/history.exe?\&I21DBN=EIU\&P21DBN=EIU\&S21STN=1\&S21REF=10\&S21FMT=eiu_all\& $\mathrm{C} 21 \mathrm{COM}=\mathrm{S} \& S 21 \mathrm{CNR}=20 \& S 21 \mathrm{P} 01=0 \& S 21 \mathrm{P} 02=0 \& S 21 \mathrm{P} 03=\mathrm{TRN}=\& S 21 \mathrm{COLORTERMS}=0 \& S 2$ 1STR=Statuty_V (дата звернення: 29.11.2019)

9. Положение о воинских преступлениях от 27 июля 1927 г. (1927). Сборник законов и распоряжений СССР. 1927. № 50. Ст. 505.

10. Третій Литовський $\quad$ статут 1588 p. http://wikiinfo.mdpu.org.ua/index.php?title=\%D0\%9B\%D0\%B8\%D1\%82\%D0\%BE\%D0\%B2\%D1 \%81\%D1\%8C\%D0\%BA\%D1\%96_\%D0\%A1\%D1\%82\%D0\%B0\%D1\%82\%D1\%83\%D1\%82\%D 0\%В8 (дата звернення: 29.11.2019)

11. Уголовный кодекс РСФСР редакции 1922 года. http://law.edu.ru/norm/norm.asp?normlD=1241523\&sublD=100096269,100096272,100096340, 100096440 (дата обращения: 29.11.2019)

12. Уголовный кодекс РСФСР. Официальный текст с изменениями на 15 октября 1936 г. С приложениями по систематезированым матеріалам (1936). Москва: ОГИЗ, 216 с.

13. Указ Президиума ВС РСФСР от 30.01.1984 г. (1984). Ведомости ВС РСФСР.. №5. Ст. 168.

14. Шевков, Г.В.(1970). Первый советский уголовный кодекс. Москва. 150 с. 


\section{ПРАВОВЕ ЗАБЕЗПЕЧЕННЯ ОБРОБЛЕННЯ ПОБУТОВИХ ВІДХОДІВ ПРИ ЇХ ЗАХОРОНЕННІ ЯК УМОВА ПІДВИЩЕННЯ ЯКОСТІ ЖИТТЯ}

Трегуб Олександр Андрійович

канд. юрид. наук, молодший науковий співробітник Інститут економіко-правових досліджень Національної академії наук України УКРАЇНА

Важливою умовою покращення якості життя в Україні в екологічному та інших аспектах $€$ підвищення екологічної безпечності захоронення побутових відходів, зокрема шляхом здійснення операцій з їх попереднього оброблення (сортування, знешкодження, брикетування та ін.). Однак на теперішній час таке оброблення тільки починає впроваджуватися в окремих населених пунктах і є обмеженим у кількісному та технологічному планах.

Загалом протягом 2018 р. утворилося понад 9 млн тонн побутових відходів, з яких захоронено близько 93 \%. Елементи роздільного збирання цих відходів наявні у 1462 населених пунктах із майже 29 тис. При цьому на 6 тис. полігонів і звалищ, що експлуатуються, припадає всього 34 сміттєсортувальні лінії [1; 2]. Такий стан поводження з побутовими відходами значною мірою обумовлено недоліками чинного законодавства.

Відносини у сфері захоронення побутових відходів регулюються законами України «Про охорону навколишнього природного середовища», «Про відходи», «Про благоустрій населених пунктів», Правилами експлуатації полігонів побутових відходів, затвердженими наказом Міністерства з питань житлово-комунального господарства України від 1 грудня 2010 р. № 435, та іншими нормативно-правовими актами. Водночас наведене законодавство не створює сприятливого правового середовища для повсюдного застосування сучасних технологій оброблення побутових відходів, які забезпечують вилучення з них ресурсоцінних компонентів та безпечність остаточного розміщення.

Питання правового забезпечення поводження з побутовими відходами досить активно досліджуються в юридичній науці. Останнім часом окремі з цих питань розглядали В. Зуєв, О. Гаврилюк, О. Гулак, К. Книжник, М. Кравченко, В. Кулакова, О. Мельник, Н. Обіюх, К. Хлабистова та інші науковці. Зокрема, О. Гаврилюк присвятив свою дисертацію проблемам адміністративноправового регулювання поводження з побутовими відходами [3], О. Мельник та Н. Обіюх проаналізували правові аспекти регулювання відносин у сорері поводження з цими відходами на муніципальному рівні в Україні та ЄС [4], а М. Кравченко запропонував власний погляд на систему органів виконавчої влади як суб'єктів управління побутовими відходами в Україні [5].

Разом з тим проблеми правового забезпечення оброблення побутових в контексті становлення нової якості життя в Україні не знайшли достатнього відображення у науковій літературі. Однією з таких проблем є дія заборони захоронення необроблених побутових відходів (далі - заборона захоронення) та можливість і доцільність її заміни ефективнішими правовими засобами.

Отже, тема цього дослідження є актуальною, а його мета - обгрунтувати пропозиції з удосконалення правового забезпечення оброблення побутових 
відходів при їх захороненні, що є умовою підвищення якості життя як окремих громадян, так і населення країни в цілому.

Передусім, реалізація поставленої мети передбачає з'ясування юридичного значення таких понять, як «захоронення» i «оброблення». Для цього необхідно звернутися до їх дефрініцій, закріплених у Законі України «Про відходи».

Так, згідно з цим Законом, захороненням є остаточне розміщення відходів при їх видаленні у спеціально відведених місцях чи на об'єктах таким чином, щоб довгостроковий шкідливий вплив відходів на навколишне природне середовище та здоров'я людини не перевищував установлених нормативів [6]. «Остаточним» у цьому сенсі потрібно вважати розміщення побутових відходів на довготривалу перспективу, межі якої точно визначити неможливо (до появи економічних передумов, технологій і т.д. для експлуатації звалища як джерела, або так званого «родовища» вторинних ресурсів).

Своєю чергою, під обробленням відходів Закон розуміє здійснення будьяких технологічних операцій, пов'язаних із зміною фрізичних, хімічних чи біологічних властивостей відходів, 3 метою підготовки їх до екологічно безпечного зберігання, перевезення, утилізації чи видалення [6]. Екологічна та економічна цінність оброблення полягає у тому, що завдяки відповідним операціям з побутових відходів вилучається вторинна сировина, придатна для використання у виробництві, зменшується обсяг цих відходів та знижується їх небезпека для здоров'я людини й навколишнього середовища.

3 огляду на такі міркування, у кінці 2012 р. в Україні отримала правове закріплення заборона захоронення, строк набуття чинності якої було відкладено до 1 січня 2018 р. [6; 7]. Перехідний період тривалістю у п'ять років відводився законодавцем для формування соціально-економічних, технікотехнологічних і юридичних умов, необхідних для дотримання цієї заборони.

На перший погляд, уведення заборони захоронення можна розцінювати як виконання зобов'язань України, що випливають із Додатку XXX до Глави 6 Розділу V Угоди про асоціацію з $Є C$, а саме щодо наближення національного законодавства до Директиви 1999/31/€С про захоронення відходів. Відповідно до ст. 6 цієї Директиви, держава має вживати заходів для того, щоб захороненню підлягали лише ті відходи, що пройшли оброблення [8]. Зазначені зобов'язання необхідно виконати протягом 6 років з дати набрання чинності відзначеною Угодою (для об'єктів, що існували до ії підписання). Однак їх виконання може відбуватись різними способами та в міру готовності України.

Європейський досвід свідчить, що заходи, подібні до уведення заборони захоронення, застосовують країни з високим рівнем економічного розвитку та перероблення побутових відходів (Бельгія, Нідерланди, Німеччина, Франція, Швейцарія [9]). Як правило, відповідні обмеження встановлювалися поступово з метою забезпечення нормальної адаптації до них економіки та суспільства. Наприклад, у Німеччині запровадження заборони захоронення проходило у декілька етапів з 1993 р. по 2005 р. [10].

При цьому законодавство багатьох інших європейських країн, зокрема Болгарії, Греції, Італії, Кіпру, Португалії, Словаччини, Хорватії та Чехії, такої заборони не передбачає (дані Європейської агенції довкілля станом на 2015 р.) [9]. Здебільшого це пов'язано із недостатнім рівнем перероблення 
побутових відходів, та, відповідно, великими обсягами їх захоронення. За таких обставин дотримання заборони захоронення $є$ практично неможливим.

В Україні ситуація ще складніша (ключові дані стосовно поводження 3 побутовими відходами наводилися раніше). До цього часу не вирішено первинні завдання державної політики у сфері поводження з побутовими відходами, що дозволило б перейти до розв'язання проблем вищого ступеня. Насамперед, не забезпечено стовідсоткового охоплення населення послугами з вивезення цих відходів (у 2018 р. відповідний показник складав лише $78 \%$ [1]). Повільним темпом відзначається процес технічного переоснащення виконавців послуг з вивезення побутових відходів виходячи 3 потреб їх роздільного збирання (у 2019 р. заплановано придбання 35 тис. контейнерів, з яких лише 5 тис. - для роздільного збирання таких відходів [2]).

Отже, $є$ підстави стверджувати, що введення заборони захоронення в дію з 1 січня 2018 р. є передчасним та належним чином не сприяє оздоровленню екологічної і санітарно-епідемічної ситуації у населених пунктах.

Потрібно визнати, що встановлення в Україні заборони захоронення 3 відповідної дати $є$ прикладом так званого «законодавчого випереджального відображення» регульованих відносин, моделюванням їх бажаного образу. Як підкреслює Д. Керімов, умовою ефективності правового регулювання, яке враховує момент випередження, $€$ володіння законодавцем максимально повною та об'єктивною інформацією про об'єкт регулювання [11]. Водночас законодавець повинен не лише оволодіти, але й правильно використати цю інформацію для того, щоб знайти оптимальну «відстань» між фрактичними відносинами та їх випереджальною правовою моделлю.

Якщо виходити із засад державної регуляторної політики, це означає, що розробник регуляторного акту має на основі точних даних про поточний і прогнозований стан поводження з побутовими відходами визначити та оцінити усі альтернативні способи досягнення поставлених цілей, а також аргументувати переваги обраного ним способу [12]. При обґрунтуванні вибору важливим також $€$ аналіз зарубіжного законодавства й практики його реалізації.

3 юридичного погляду, оброблення побутових відходів $є$ ціллю правового регулювання, а заборона їх захоронення у необробленому стані - способом ії досягнення. У теорії права під забороною розуміється покладення на особу обов'язку пасивно утримуватися від певних дій (негативне зобов'язування) [13]. Однак для припинення захоронення необроблених побутових відходів потрібні не пасивні, а активні дії зобов'язаних суб'єктів. Тому логічнішим $\epsilon$ обрання в цій ситуації іншого способу правового регулювання - позитивного зобов'язування.

Далі необхідно виважено визначити дальність випередження наявного стану відносин у досліджуваній сфері, тобто як і коли повинні виглядати такі відносини. Для цього на операторів звалищ та інших суб'єктів захоронення побутових відходів пропонується покласти обов'язок щодо забезпечення їх оброблення у кількості, що буде поетапно збільшуватися.

Ураховуючи часові витрати на модернізацію інфраструктури розміщення побутових відходів, у тому числі облаштування полігонів комплексами 3 сортування та брикетування, організації на них окремих робочих карт для «звичайних» та брикетованих відходів і т.д., доцільно встановити шість кількісних рівнів оброблення вказаних відходів (число, значення рівнів і строки 
їх проходження $є$ умовними й можуть коригуватися). Сходження на перший рівень (25\% від обсягу побутових відходів, що підлягають захороненню) розраховано на п'ять років. Кожний наступний показник дорівнює значенню попередніх плюс 15 \% і стає обов'язковим зі спливом дворічного строку. Отже, стовідсотковий рівень оброблення побутових відходів при їх захороненні досягатиметься поступово за шкалою, що прогресує у часі.

Загальнодержавна шкала відповідного обов'язку заснована на принципі мінімально прийнятної кількості, у зв'язку з чим може уповільнювати процес удосконалення збирання та захоронення побутових відходів у деяких населених пунктах і регіонах країни. Зважаючи на це, сільські, селищні та міські ради необхідно наділити повноваженням щодо збільшення на своїй території рівня обов'язкового оброблення побутових відходів при їх захороненні.

Таким чином, заборона захоронення необроблених побутових відходів не $\epsilon$ ефективним засобом покращення якості життя мешканців окремих територій та населення країни загалом. 3 огляду на це, запропоновано замінити таку заборону на обов'язок суб'єктів захоронення побутових відходів забезпечувати їх оброблення у кількості, що поступово зростатиме.

\section{Список використаних джерел:}

1. Стан сфрери поводження з побутовими відходами в Україні за 2018 рік. (2019). Вилучено 3 http://www.minregion.gov.ua/napryamki-diyalnosti/zhkh/terretory/stan-sferi-povodzhennya-zpobutovimi-vidhodami-v-ukrayini-za-2018-rik/

2. Інформація щодо впровадження сучасних методів та технологій у сфрері поводження з побутовими відходами. (2019). Вилучено 3 http://www.minregion.gov.ua/napryamkidiyalnosti/zhkh/terretory/informatsiya-shhodo-vprovadzhennya-suchasnih-metodiv-ta-tehnologiyu-sferi-povodzhennya-z-pobutovimi-vidhodami-4/

3. Гаврилюк, О. О. (2017). Адміністративно-правове регулювання поводження з побутовими відходами (автореф. дис. ... канд. юрид. наук). Науково-дослідний інститут публічного права. Київ, Україна.

4. Мельник, О. \& Обіюх, Н. (2019). Правові аспекти регулювання відносин у сфері поводження з побутовими відходами на муніципальному рівні в Україні та $Є С$ в умовах децентралізації. Підприємниитво, господарство і право, (3), 127-131.

5. Кравченко, М. Г. (2018). Органи виконавчої влади як суб'єкти управління побутовими відходами в Україні. Науковий вісник Ужгородського національного університету. Серія ПРАВО, (1, 51), 198-201.

6. Про відходи (Закон України). № 187/98-BP. (2019). Вилучено з https://zakon.rada.gov.ua/laws/show/ru/187/98-\%D0\%B2\%D1\%80

7. Про внесення змін до деяких законодавчих актів України щодо вдосконалення механізму правового регулювання та посилення відповідальності у сфері поводження з відходами (Закон України). № 5402-VI. (2019). Вилучено з https://zakon.rada.gov.ua/laws/show/ru/540217? find=1\&lang=ru\&text=\%D0\%BD\%D0\%B5\%D0\%BE\%D0\%B1\%D1\%80\%D0\%BE\%D0\%B1\% D0\%BB\#w13

8. On the landfill of waste (Directive of the European Union). № 1999/31/EC. (2019). Removed from https://eur-lex.europa.eu/legal-content/EN/TXT/?uri=CELEX:01999L0031-20180704

9. Table 3.1 Municipal solid waste (MSW) management and selected policy instruments in European countries, 2001-2015. (2019). Removed from https://www.eea.europa.eu/themes/waste/wastemanagement/municipal-waste-management-across-european-countries/table-3-1-municipal-solid

10. Municipal waste management. Germany. (2016). Removed from https://www.eionet.europa.eu/etcs/etc-wmge/products/otherproducts/docs/germany_msw_2016.pdf 
11. Керимов, Д. А. (2001). Методология права (предмет, фуункции, проблемы фиилософии права). Москва: Аванта+.

12. Про засади державної регуляторної політики у сфрері господарської діяльності (Закон України). № 1160-IV. (2019). Вилучено 3 https://zakon.rada.gov.ua/laws/show/1160-15

13. Алексеев, С. С., Архипов, С. И., Игнатенко, Г. В., Корельский, В. М., Леушин, В. И., Перевалов, В. Д., ... Шабуров, А. С. (2002). Теория государства и права. Москва: Издательство НОРМА.

\title{
ПРАВОВЕ РЕГУЛЮВАННЯ КОНТЕНТУ В МЕРЕЖІ ІНТЕРНЕТ У НІМЕЧЧИНІ ТА УКРАЇНІ: ПОРІВНЯЛЬНИЙ АСПЕКТ
}

\begin{abstract}
Кулинич Аліна Юріївна
здобувач вищої освіти

Полтавський юридичний інститут

Національного юридичного університету імені Ярослава Мудрого

УКРАЇ̈А
\end{abstract}

Питання правового регулювання фрільтрації контенту в Інтернет-мережі $\epsilon$ особливо актуальним у сучасному суспільстві. 3 одного боку, це обумовлено стрімким розвитком IT-сфери, оскільки майже щодня створюються нові програми, технології, які пов'язані з розміщенням та використанням інформації у тому чи іншому вигляді, що викликає неабиякий інтерес у молодого покоління. Регулювання змісту відомостей, які можуть бути використані у цьому процесі і $є$ предметом цього дослідження. 3 іншого боку, в умовах інформаційної війни важливо встановлювати вимоги та правила розміщення відповідних даних у Інтернет-просторі. Тому дослідження іноземного досвіду щодо регулювання контенту у Всесвітній мережі дозволить виявити як позитивні, так і негативні аспекти вітчизняної законодавчої бази, та надати рекомендації для ії удосконалення.

Розпочати необхідно з визначення національних нормативно-правових актів, які регулюють Інтернет-контент. Але проблема полягає у тому, що в Україні відсутнє чітке, системне, цілісне правове регулювання цієї сфери. Окремі норми, що регулюють ці питання, розпорошенні у різних актах. Одним з таких документів $€$ «Доктрина інформаційної безпеки України», затверджена Указом Президента України від 25 лютого 2017 року № 47/2017. Зокрема, у розділі 3 цього документу визначено основні національні інтереси України у інформаційній сфрері: захист від руйнівного інформаційно-психологічного впливу, деструктивної пропаганди, агресивного впливу Російської Федерації, спрямованого на пропаганду війни та іншим чином ослаблення нашої держави. Для забезпечення цього визначено, що пріоритетами держави має бути законодавче регулювання механізму фрільтрації інформації, яка суперечить вищевказаним інтересам. Також зазначено, що на Міністерство інформаційної політики має бути покладено здійснення моніторингу дотримання національних інтересів у інформаційній сфері [1]. Проте, варто звернути увагу, що відповідно до Положення про Міністерство інформаційної політики України, 
затвердженого Постановою КМУ від 14 січня 2015 р. № 2, такі повноваження відсутні [2]. Можна сказати, що фрактично Доктрина інформаційної безпеки України не реалізовується, оскільки для цього потрібне прийняття відповідних законів та інших нормативно-правових актів, які будуть спрямовані на реалізацію її положень. Водночас, доцільно виокремити і позитивний аспект, зокрема те, що встановлюється перелік відомостей, яких не має бути в мережі Інтернет. Аналогічна ситуація і зі «Стратегією кібербезпеки України», затвердженою Указом Президента України від 15 березня 2016 року № 96/2016 [3]. Стратегією передбачаються ціла низка заходів для забезпечення інформаційної безпеки, проте багато з них досі не реалізовані.

Якщо говорити про закріплення заборонених відомостей на рівні законів, то слід проаналізувати Закон України «Про інформацію», відповідно до ст. 28 якого інформацію забороняється використовувати для закликів для повалення конституційного ладу, пропаганди війни, насильства, жорстокості, порушення прав та свобод людини [4]. Крім того, в Україні діє ЗУ «Про телекомунікації», реалізацію якого покладено на Національну раду України з питань телебачення та радіомовлення та на Національну комісію, що здійснює регулювання у сфері зв'язку та інформатизації. Проте, як зауважує О. Солдатенко, даний закон та діяльність цих органів спрямовані на технічну сторону регулювання мережі Інтернет, а не на змістовне наповнення [5].

Позитивним у цьому аспекті видається досвід ФРН. Так, основоположним актом щодо регулювання контенту можна вважати закон «Про покращення правозастосування у соціальних мережах» від 01 жовтня 2017 р. [6]. Цей закон містить перелік неправомірного контенту, шляхом відсилання до низки статей Кримінального кодексу ФРН. Порівнюючи список криміналізованих діянь щодо поширення забороненого контенту в Інтернеті з українським законодавством, очевидним є те, що Німеччина приділяє набагато більше уваги цій сфері. Зокрема, встановлено кримінальну відповідальність, наприклад, за підробку і поширення неправдивих відомостей про ФРН, якщо це могло б заподіяти шкоду її інтересам (§100a), за поширення матеріалів, які можуть бути вказівкою для вчинення протиправних дій іншою особою (§130a), за наклеп (§186) тощо [7]. Також важливим $€$ те, що вищевказаний закон покладає низку обов'язків на соціальні та інші мережі, які мають більше двох мільйонів зареєстрованих користувачів, основним з яких $є$ видалення протягом встановленого періоду часу постів, які містять неправомірний контент. У протилежному випадку, у разі систематичності, може бути накладений штрафр у розмірі п'яти мільйонів євро [6].

Щодо України можна відзначити, що правове регулювання соціальних мереж взагалі відсутнє. Тому, на нашу думку, прийняття у нашій державі подібного нормативно-правового акту може значно покращити ситуацію. Зокрема, у такому акті доцільно було б закріпити, по-перше, перелік забороненого контенту або ж послатися на Доктрину інформаційної безпеки України, де міститься список охоронюваних інтересів у цій сфері, по-друге, покласти на власників соціальних мереж обов'язки з фільтрації контенту та встановити механізм контролю за їх виконанням, та, по-третє, - закріпити відповідальність зобов'язаних суб'єктів та порядок притягнення до неї. 
Ще одним важливим актом у Німеччині виступає закон «Про регулювання поширення записів і медіа-контенту, шкідливого для молоді» від 12 червня 1985 р.. Перелік забороненого контенту закріплено шляхом посилання на норми Кримінального кодексу ФРН, а також вказівкою на інші матеріали, які можуть завдати шкоди моральності цієї категорії населення. Варто зауважити, що даний закон хоча не регулює виключно відносини щодо інформації в мережі Інтернет, проте детально регулює захист дітей від небажаного контенту [8]. Повертаючись до вітчизняного законодавства, позитивним моментом $є$ те, що стосовно захисту, у тому числі молоді, є Закон України «Про захист суспільної моралі» від 20 листопада 2003 р. [9]. Але, водночас, щодо контенту можна використати лише положення щодо порнографічних та інших еротичних матеріалів, оскільки механізм захисту від інших видів шкідливої інформації не передбачено.

Відмінною рисою у правовому регулюванні Інтернет-контенту у Німеччині $\epsilon$ те, що в них досить поширена практика договірного регулювання змісту мережі Інтернет. Угоди про моніторинг і контроль укладаються як між державою і провайдерами, так і між останніми самостійно [10]. В Україні така практика відсутня. Можливо, з одного боку, це через відсутність ініціативи держави, а, з іншого боку, - у інтернет-провайдерів відсутній обов'язок укладати подібні угоди і вони не захочуть обтяжувати себе додатковими зобов'язаннями.

Отже, в Україні правове регулювання контенту у мережі Інтернет майже відсутнє. Хоча позитивним аспектом $€$ те, що приймаються відповідні стратегії, у яких визначається перелік дій, які необхідно здійснити для фрільтрації інформації в Інтернеті. Тому наразі існує нагальна потреба у прийнятті законів, які закріплювали б механізм реалізації цих положень. Вважаємо за доцільне використати досвід Німеччини, яка декількома актами встановила основні правила розміщення і використання контенту у Всесвітній мережі.

\section{Список використаних джерел:}

1. "Доктрина інформаційної безпеки України", затверджено Указом Президента України. № 47/2017. (2017). Вилучено з: https://zakon.rada.gov.ua/laws/show/47/2017.

2. Положення про Міністерство інформаційної політики України, затверджене Постановою КМУ. № 2. (2015). Вилучено 3: https://zakon.rada.gov.ua/laws/show/2-2015-\%D0\%BF.

3. Стратегія кібербезпеки України, затверджена Указом Президента України. № 96/2016. (2016). Вилучено з: https://zakon.rada.gov.ua/laws/show/96/2016\#n11.

4. Про інфрормацію (Закон України). № 2657-XII. (1992). Вилучено з: https://zakon.rada.gov.uallaws/show/2657-12\#n184.

5. Солдатенко О. (2018). Інформаційний простір у мережі Інтернет:правове регулювання та контроль. Підприємництво, господарство і право, (5), 134-140.

6. Про покращення правозастосування у соціальних мережах (Закон ФРН). (2017). Вилучено 3: https://germanlawarchive.iuscomp.org/?p=1245.

7. Уголовный кодекс ФРГ. Вилучено 3 https://constitutions.ru/?p=5854.

8. Про регулювання поширення записів і медіа-контенту, шкідливого для молоді (Закон ФРН). (1985). Вилучено 3: https://germanlawarchive.iuscomp.org/?p=722\#6.

9. Про захист суспільної моралі (Закон України). № 1296-IV. (2003) Вилучено з: https://zakon.rada.gov.ua/laws/show/1296-15.

10. Кузьміч А. (2017). Законодавче регулювання та способи фільтрації шкідливого інтернетконтенту: міжнародний досвід. Вилучено 3: http://telpu.com.ua/archives/1872. 


\section{ПРОБЛЕМАТИКА МІЖНАРОДНОЇ ВІДПОВІДАЛЬНОСТІ ООН У РАЗІ НЕПРАВОМІРНОГО ЗАСТОСУВАННЯ СИЛИ}

Коба Ірина Володимирівна

студентка 3 курсу

Полтавський юридичний інститут

Національного юридичного університету ім. Ярослава Мудрого

НАУКОВИЙ КЕРІВНИК:

Гаркуша Андрій Олександрович

канд. юрид. наук, доцент кафедри цивільного, господарського і фінансового права

Полтавський юридичний інститут Національного юридичного університету ім. Ярослава Мудрого

УКРÄ̈HA

Світове співтовариство активно рухається вперед на шляху загальної глобалізації, внаслідок чого на світовій арені з кожним роком посилюється роль міжнародних міжурядових організацій. А отже, враховуючи специфічний обсяг їх правосуб'єктності, постає питання: чи несуть такі організації відповідальність і яким саме чином?

Ще більше це питання актуалізується у розрізі неправомірного застосування сили, адже в останні роки міжнародні протистояння значно загострилися і навіть Україна стала ареною кровопролитного конфлікту. В умовах періодичної дестабілізації ситуації у світі важливим $€$ існування системи засобів притягнення у разі неправомірного застосування сили до відповідальності організацій, які своїм основним статутним завданням проголошують підтримання та зміцнення миру, зокрема і ООН.

Проблематика міжнародної відповідальності $\mathrm{OOH}$ у разі неправомірного застосування сили та дослідження ії̈ міжнародноправової характеристики $€$ порівняно новою. До окремих аспектів цього питання зверталися такі вітчизняні та зарубіжні вчені, як Р. Бакен, Є. Блюм, О. В. Буткевич, І. М. Забара, О. В. Задорожній, Д. О. Коваль, Ю. М. Колосов, Є. В. Магда, Б. Мерті, А. В. Пазюк, В. С. Ржевська, та ін. Водночас, ключові аспекти міжнародної відповідальності $\mathrm{OOH}$ у разі неправомірного застосування сили ще не стали об'єктом спеціального вивчення в сучасній українській науці міжнародного права і лише частково розкриваються в роботах зарубіжних дослідників. Таким чином, обрана тема характеризується недостатнім рівнем своєї дослідженості та загальною необхідністю надання міжнародно-правової характеристики відповідальності ООН.

Метою дослідження $€$ розгляд основних правових позицій стосовно проблематики юридичних підстав відповідальності за акти неправомірного застосування сили ООН. Для досягнення зазначеної мети поставлені завдання з встановлення основних підходів до визначення суб'єктів відповідальності за неправомірне застосування сили при проведенні миротворчих операцій та обґрунтування необхідності нормативно-правового регулювання цього питання на міжнародному рівні. 
У разі зловживання силою при проведенні миротворчої операції ООН можуть виникнути чотири групи проблем, пов'язані зі сферою міжнародної відповідальності:

1) проблема індивідуальної відповідальності миротворців - членів миротворчих контингентів $\mathrm{OOH}$;

2) проблема відповідальності держав, що надають свої контингенти для участі в миротворчій місії;

3) проблема відповідальності приватних військових і охоронних підприємств, які залучаються до участі в миротворчій операції;

4) проблема відповідальності власне $\mathrm{OOH}$ як міжнародної міжурядової організації.

У особливу групу проблем також можна виділити питання кумулятивної відповідальності вищеназваних суб'єктів.

Отже, перша проблема пов'язана з відповідальністю індивідів у зв'язку з участю в миротворчих операціях $\mathrm{OOH}$. В одному зі звітів Міжнародного суду сказано, що всі представники Організації Об'єднаних Націй, в якому б офрційному статусі вони не діяли, повинні проявляти обачність, з тим щоб не виходити за рамки своїх функцій і вести себе таким чином, щоб уникнути пред'явлення претензій до Організації.

Однак очевидно, що на практиці це далеко не завжди можливо, навіть в діяльності, не пов'язаній з миротворчою діяльністю. Наприклад, в 1954 році Генеральний директор ЮНЕСКО, перевищивши свої повноваження, звільнив сімох співробітників Секретаріату ЮНЕСКО. У зв'язку з цим ЮНЕСКО, що відповідає за дії свого Генерального директора, понесла матеріальну відповідальність і була змушена сплатити близько 75 тис. дол. колишнім співробітникам Секретаріату.

На сьогоднішній день індивідуальна відповідальність реалізується в основному в формі застосування дисциплінарних стягнень до військовослужбовців місій ООН, які були причетні до різних порушень. Дані заходи реалізуються Департаментом польової підтримки Секретаріату ООН. Крім того, з 2004 року Генеральний секретаріат ООН провів ряд масштабних рефрорм щодо норм поведінки, проведення розслідувань, організаційної, управлінської та командної відповідальності, а також індивідуальної дисциплінарної, фінансової та кримінальної підзвітності миротворців, а також прийняв ряд заходів щодо попередження та покарання в зв'язку з сексуальним насильством і експлуатацією під час оонівських операцій, зокрема резолюцію Ради безпеки ООН 1820 (2008) щодо жінок, миру і безпеки [1, с. 40].

Важливу роль в цьому питанні відіграє діяльність Міжнародного кримінального суду, який має юрисдикцію щодо злочинів проти людяності, військових злочинів і геноциду, в тому числі в тих випадках, коли такі злочини вчиняються з боку миротворців ООН [2].

Крім того, не варто також применшувати важливість національного правосуддя у відповідних державах, громадянами яких $є$ правопорушники. Держави, які направляють персонал у міжнародні місії з підтримання миру, повинні забезпечити можливість проведення незалежних розслідувань і повної підзвітності тих, хто несе відповідальність за порушення прав людини, в тому числі на підставі кримінальних, адміністративних і дисциплінарних процедур, коли це доцільно. 
У Проекті кодексу злочинів проти миру і безпеки людства 1996 року Комісією з міжнародного права було особливо підкреслено: «той фракт, що цей Кодекс передбачає відповідальність окремих осіб за злочини проти миру та безпеки людства, не завдає шкоди жодному питанню відповідальності держав за міжнародним правом». При цьому очевидно, що саме питання про відповідальність держав в процесі реалізації ООН миротворчої функції $€$ одним з найбільш важливих і принципових: «оскільки жодна організація в даний час не має власних збройних сил, організації при здійсненні миротворчої місії змушені покладатися на той військовий і цивільний персонал, який нададуть їм держави» [3, с. 6].

Сказане рівною мірою стосується національних контингентів, що надаються в розпорядження Організації Північноатлантичного альянсу або будь-якої іншої організації з відповідною компетенцією. Відповідно, при вирішенні питань, пов'язаних з міжнародною відповідальністю, неминуче постає питання про те, хто ж здійснював фактичний контроль над солдатами в ході операції - відповідні держави або ж міжнародна організація.

Генеральний секретар $\mathrm{OOH}$ відзначав, що «визнання того факту, що Організація Об'єднаних Націй несе міжнародну відповідальність за діяльність своїх сил, вона з моменту заснування Операцій з підтримання миру брала на себе відповідальність за шкоду, яку завдають члени її сил при виконанні своїх обов'язків»[4]. Однак, на практиці визнання членів миротворчих місій винуватими в протиправній поведінці є ускладненим, так як зазвичай їх дії або бездіяльність можуть бути поставлені у вину державам, які надають війська, або міжнародній організації, або і тим, і іншим.

У цій ситуації зіткнення інтересів держав і міжнародної організації як самостійного суб'єкта міжнародного права, що володіє автономією волі, практично неминуче. Хто ж у разі неправомірного застосування сили в ході миротворчої операції несе за це відповідальність - ООН або ж держава, яка надала війська? Очевидно, що ані практика, ані доктрина поки не дають однозначної відповіді на це питання.

По суті, всі теорії в сфері визначення міжнародної відповідальності за перевищення повноважень або неправомірне застосування сили при проведенні миротворчих операцій зводяться до трьох основних позицій:

1) міжнародну відповідальність повинні нести держави, що надають свої військові контингенти;

2) міжнародну відповідальність повинна нести $\mathrm{OOH}$, так як саме під її егідою і прапором проводяться миротворчі операції;

3) відповідальність повинні нести і держави, і ООН спільно [5, с. 491].

Перша позиція Ґрунтується на тому, що ООН ніколи не має абсолютної влади над національними контингентами, які надані в її розпорядження, так як держави завжди зберігають переважний контроль. Класичним прикладом подібної складної ситуації, коли необхідно визначити, хто ж здійснює ефективний контроль над миротворчою операцією - ООН або ж держави, $\epsilon$ бомбардування американськими ВПС цілей на території Китаю і СРСР в період війни в Кореї в 1950 році. Уряд США визнав свої дії помилковими, однак спочатку наполягав на тому, що відповідальність повинна нести ООН в Кореї. Пізніше США погодилися «визнати відповідальність і виплатити компенсацію через ООН за шкоду, яка була заподіяна силами США і визначена в результаті безстороннього розслідування на місці [5, с. 492]. 
Саме тому деякі дослідники вважають, що відповідальність в кінцевому рахунку повинні нести тільки держави. Якщо національний контингент діє ultra vires через тиск з боку держави, яка його надала, то поведінка повинна ставитися у вину тільки цій державі.

Друга позиція, заснована на переважній відповідальності ООН за дії миротворчих контингентів, полягає в тому, що порушення міжнародних зобов'язань членами миротворчих сил ООН повинні безпосередньо ставитися в вину самій організації, а не державам-членам, що забезпечує контингент, до якого прикріплені миротворці[5, с. 492].

Третя позиція може бути охарактеризована як концепція «розділеної відповідальності» (shared responsibility). Національні контингенти, що $є$ частиною миротворчих сил ООН, мають подвійний інституційний статус - як органи своєї держави і як частина органу ООН. У свою чергу, при визначенні ступеня відповідальності використовується критерій «ефективне управління», або «ефективний контроль», який був озвучений ще в 1996 році. Міжнародна відповідальність Організації Об'єднаних Націй в зв'язку з бойовими діями сил Організації Об'єднаних Націй ґрунтується на припущенні про те, що ця операція здійснюється під виключним командуванням та управлінням Організації. При спільних операціях міжнародна відповідальність за дії військ лежить на тих, хто здійснює оперативне командування і управління відповідно до домовленостей, у яких визначаються умови співпраці між державою або державами, що надають війська, і Організацією Об'єднаних Націй. За відсутності фрормальних домовленостей між ООН і державою або державами, що надають війська, відповідальність буде визначатися в кожному випадку в залежності від ступеня ефективного управління, здійснюваного кожною зі сторін при проведенні операції [5, с. 493].

Враховуючи вищевказане, на нашу думку, максимально доцільним $€$ дотримання третьої позиції, адже врегулювання питань щодо відповідальності повинно розглядатися в кожній ситуації окремо в залежності від ступеня ефективного управління, здійснюваного ООН та відповідними державами при проведенні операції. В свою чергу, певного доопрацювання потребують перші дві позиції, адже, на нашу думку, вони в певній мірі обмежують права сторін, не врегулювавши спірні питання до кінця.

3 наведеного вище можна дійти наступних висновків:

1. Відповідальність міжнародної організації випливає з факту порушення ії органами і посадовими особами статутних положень організації та загальних норм міжнародного права.

2. У міжнародному праві відсутня єдність думок щодо визначення міжнародної відповідальності за неправомірне застосування сили при проведенні миротворчих операцій, проте найбільш аргументованою, на нашу думку, $є$ позиція розділення відповідальності між державами, які надають війська та $\mathrm{OOH}$.

3. Враховуючи, попередній висновок, з урахуванням того факту, що нині у практиці проблема відповідальності міжнародних організацій, як правило вирішується лише у площині компенсації завданих матеріальних збитків, враховуючи ключове значення ООН у процесі становлення та збереження миру, вважаємо за необхідне нормативно закріпити детальний алгоритм відповідальності ООН у разі неправомірного застосування сили. 
Таким чином, багато аспектів, пов'язаних із відповідальністю Організації Об'єднаних Націй, поки знаходяться в стані розробки, що пов'язано 3 недостатнім розвитком тематики відповідальності міжнародних організацій в цілому. Безумовно, проблематика відповідальності ООН і міжнародних організацій вимагає поглибленого вивчення та подальшої доктринальної розробки.

\title{
Список використаних джерел:
}

1. Лисак, Я.А. (2015) Відповідальність військовослужбовців під час виконання ними службових обов'язків за кордоном, в операціях із підтримки миру і безпеки. Науковий вісник Ужгородського національного університету (33), 38-42.

2. Доповідь Групи по операціям на користь миру. Вилучено із: http://www. un.org/russian/peace/reports/ peace_operations/docs/ summary .

3. Draft Code of Crimes against the Peace and Security of Mankind (1996). Вилучено із : http:/l legal.un.org/ilc/texts/instruments/english/draft\%20articles/7_4_1996.pdf.

4. U.N. Doc. A/51/389. Administrative and budgetary aspects of the financing of the United Nations peacekeeping operations: financing of the United Nations peacekeeping operations Report of the Secretary-General. (1996).

5. Денисова, Д.О. (2017) Міжнародно-правова відповідальність міжнародних міжурядових організацій в миротворчих операціях. Актуальні проблеми держави і права. (6), 488-497.

\section{СПІВВІДНОШЕННЯ НОРМ ПРАВА ТА НОРМ ПОВЕДІНКИ ПЕРВІСНОГО СУСПІЛЬСТВА}

\author{
Біліченко Валерій Віталійович \\ Викладач кафедри тактико-спеціальної підготовки \\ Дніпропетровський державний університет внутрішніх справ \\ УKPAÏHA
}

Вагомий внесок у дослідження проблеми виникнення соціальних норм внесли відомі вітчизняні та зарубіжні вчені, зокрема: В. Алексєєв, Є. Бурлай, С. Гусарєв, Т. Кашаніна, М. Кельман, В. Копєйчиков, Н. Крестовська, С. Лисенков, Л. Матвєєва, М. Матузов, П. Недбайло, В. Нерсесянц, Н. Оніщенко, Н. Пархоменко, А. Першиць, О. Скакун, Т. Тарахонич, В. Теліпко, О. Тихомиров, І. Усенко та ін.

Виникнення права стало закономірним результатом розвитку суспільства та його нормативної системи. Зароджуючись ще в надрах первісної общини (на етапі утворення вождівств або протодержав), воно майже не відрізнялося від звичаїв первісної общини. I тільки з часом, заявивши свої претензії на роль основного регулятора суспільних відносин, право набуло специфічних для нього властивостей, форм виразу і стало сприйматися як певна соціальна цінність.

Відмінності права від соціальних норм первісної общини полягають у такому: 
1.Право фрормувалося шляхом визнання і захисту державою ускладнених суспільних відносин, що постійно повторюються. Згодом виникли правові приписи, які встановлювалися або санкціонувалися компетентними державними органами (у тому числі судовими). В структурі права разом 3 нормами, прийнятими державою, стали вирізняти природні права, принципи права, корпоративні і договірні норми, що свідчить про наявність декількох автономних суб'єктів право утворення.

Соціальні норми первісної общини складалися внаслідок багаторазового повторення найдоцільніших варіантів поведінки, єдиним суб'єктом їх утворення була вся община.

2.На перших етапах свого розвитку право сприяло вирішенню всезагальних справ у галузі виробництва, розподілу та перерозподілу продуктів, нормувало індивідуальні витрати праці на суспільні потреби (архаїчне право). У процесі станового розшарування населення воно почало слугувати інтересам окремих соціальних верств: феодалів (феодальне право), духовенства (канонічне право), мешканців міст (міське, торгове, цехове право) і використовуватися для регулювання відносин усередині станів. У класових суспільствах право закріплювало економічну і соціальну нерівність, привілеї панівного класу. Поступово намітилася тенденція повернення права на більш високому рівні до забезпечення реалізації загально соціальних функцій.

Соціальні норми первісної общини виражали загальну волю всіх її членів і сприяли соціалізації життя общини.

3.Право спочатку існувало у вигляді схвалених державою фрактичних, повторюваних суспільних відносин, які набували правового характеру. 3 часом воно закріплюється і виражається в письмових, офіційних джерелах - законах, судових прецедентах, нормативних договорах тощо.

Соціальні норми первісної общини виражалися в обрядах, ритуалах, міфах, табу, звичаях, тобто існували переважно в усній формі, передавалися із покоління в покоління і втілювалися в фрактичній поведінці людей.

4.Право встановлює загальні дозволи, веління, заборони, його норми чітко закріплюють критерії правомірності поведінки. Завдяки такій визначеності суб'єкти права знають про свої права і свободи, способи їх захисту, покладені на них обов'язки, заходи відповідальності, передбачені санкціями правових норм.

Соціальні норми первісної общини не знали поділу на права і обов'язки, не містили санкцій.

5.У державно організованому суспільстві реалізація права хоч i розрахована на добровільне, свідоме виконання його приписів, але в разі їх порушення передбачає можливість застосування державного примусу. Для цього існує спеціальний апарат контролю і нагляду, розв'язання спорів, поновлення правопорядку.

Реалізація соціальних норм первісної общини забезпечувалася переважно силою авторитету, звички, внутрішнього переконання, громадського осуду.

Отже, за своїми основними характеристиками - змістом, способами регулювання, формами виразу, засобами забезпечення право істотно відрізняється від усіх попередніх нормативних регуляторів, притаманних додержавним суспільствам. 


\title{
Список використаних джерел:
}

1. Скакун, О. Ф. (2008). Обшее сравнительное проведение: основне типы (семи) правових систем мира. Київ: Ін Юре.

2. Лисюк, І.І.(2011). Деякі питання виникнення соціальних норм. Часопис Київського університету права, (3), 65

3. Толкачова, Н.Є. (2007). Звичаєве право в системі соціально - ціннісних установлень i нормативного регулювання відносин. Науковий вісник Чернігівського університету, (375), 34-35.

4. Толкачова, Н. Є. (2002). Деякі аспекти співвідношення звичаю, традиції та права. Вісник КНУ Шевченка: Сер. Юридичні науки, (45), 20-22.

5. Буша, Н. (2011). Науково - методологічні засади мононорм - звичаїв і транссрормація їх у загальне право. Підприємство, господарство і право, (4), 91.

\section{СПІЛЬНА АГРАРНА ПОЛІТИКА ЄС: ОСНОВНІ НАПРЯМКИ РОЗВИТКУ НА 2020-2027 РОКИ}

\author{
Кулинич Аліна Юріївна \\ здобувач вищої освіти \\ Полтавський юридичний інститут \\ Національного юридичного університету імені Ярослава Мудрого \\ УКРАЇHA
}

На сьогодні Європейський сільськогосподарський сектор обмежений інституційними нормами САП (Common agricultural policy), яка $є$ гарантом позитивних змін у сільському господарстві та «захисником» інтересів фермерів в умовах жорстокої ринкової конкуренції. САП вживає заходів з підтримки доходів сільськогосподарських товаровиробників за рахунок прямих платежів, забезпечує стабільність доходів і винагороджує фермерів за екологічно безпечне ведення сільського господарства і здійснення інших суспільно корисних заходів, наприклад, турбота про сільську місцевість, здійснює заходи з розвитку сільських місцевостей з національними і регіональними програмами для вирішення конкретних потреб і проблем, з якими стикаються сільські райони [1]. Європі необхідний стійкий і конкурентоспроможний сільськогосподарський сектор для забезпечення виробництва високоякісних, безпечних і доступних продуктів харчування для ії громадян і сильної соціально-економічної структури в сільських районах, і САП робить значний внесок в досягнення всіх цих цілей.

Оскільки програма САП, яка діє зараз, затверджена лише до 2020 р., то доцільно розглянути основні напрямки подальшого розвитку САП в ЄС. На період 2021-2027 рр. Європейська комісія пропонує чималий загальний бюджет, з якого велика частка буде виділена на аграрний сектор, що підкреслює важливість даної політики.

Бюджет САП буде розділений між двома його традиційними «блоками»: пряма підтримка фрермерів (прямі платежі) та розвиток сільської місцевості [2]. Для того, щоб дозволити державам-членам краще адаптувати політику до 
пріоритетів свого сільського господарства, вони матимуть можливість переводити до $15 \%$ їх асигнувань із САП між прямими платежами та розвитком сільських територій. САП стимулюватиме і підтримуватиме більш широке використання сучасних технологій та інновацій. Більш високі амбіції, зокрема щодо навколишнього середовища та клімату, будуть доповнені низкою стримувань і противаг для забезпечення того, щоб як фермери, так і державичлени виконували свої зобов'язання. Нова САП буде особливо зосереджена на підтримці малих i середніх сімейних ферм, які $\epsilon$ серцем сільськогосподарського способу життя $€$, а також на заохоченні молодих фермерів приєднуватись до професії. Будуть розроблятися програми наставництва старших фермерів над молодими, поліпшення передачі знань між поколіннями тощо. На додаток до обов'язкових вимог, фермери матимуть можливість зробити свій внесок і отримувати додаткову підтримку за допомогою різних добровільних схем. Фермери будуть винагороджені за перевиконання обов'язкових вимог, взятих на себе зобов'язань, стосовно агросередовище та / або клімату [3].

Аналізуючи наявні джерела щодо розподілу асигнувань для окремих країн, можна дійти висновку, що кожна держава-член самостійно розроблятиме екосхеми для підтримки та / або стимулювання фермерів дотримуватись сільськогосподарської практики, сприятливої для клімату та оточуючого середовища, понад встановлених обов'язкових вимог.

Отже, САП є дієвим механізмом підтримки та розвитку аграрного сектору у Європі. Важливість даного інструментарію для ЄС i, взагалі, для всього світу, як прикладу вдалої системи управління аграрним і сільським розвитком, підкреслюється тим, що Єврокомісія продовжує надалі вдосконалювати САП не лише у бік більшої підтримки аграріїв, а й стосовно покращення екології.

\section{Список використаних джерел:}

1. Зінчук, Т. О. (2017). Сучасна парадигма Спільної аграрної політики ЄС як протидія глобальним викликам та дезінтеграції. Економіка АПК. (10), 78-85.

2. Попова, О. Л. (2013). Нові пріоритети Спільної аграрної політики $€ С$ на 2014-2020 роки: стратегічні орієнтири для розвитку агросфери України. Економіка АПК. (12), 89-96.

3. Future of the common agricultural policy. (2019). Вилучено 3: https://ec.europa.eu/info/foodfarming-fisheries/key-policies/common-agricultural-policy/future-cap_en 


\title{
СУБ'ЄКТИВНА СТОРОНА ЗЛОЧИНІВ ПРОТИ ЖИТТЯ ТА ЗДОРОВ'Я ОСОБИ, ВЧИНЕНИХ НА ГРУНТІ НЕНАВИСТІ
}

\author{
Казарян Елучка Гургенівна \\ Чорноморський національний університет імені Петра Могили \\ УКРАÏHA
}

Конституція України проголошує, що «людина, їі життя і здоров'я, честь і гідність, недоторканність і безпека визнаються в Україні найвищою соціальною цінністю». Також, Основний Закон України закріплює загальні принципи рівності та недискримінації, зокрема, ст. 24 закріплено, що «не може бути привілеїв чи обмежень за ознаками раси, кольору шкіри, політичних, релігійних та інших переконань, статі, етнічного та соціального походження, майнового стану, місця проживання, за мовними або іншими ознаками» [1].

В процесі євроінтеграції та становлення України як демократичної, правової держави важливе місце займає забезпечення кримінально-правової охорони життя та здоров'я особи від злочинів, вчинених на ґрунті ненависті.

Слід зазначити, що такі чинники, як: активні інтеграційні процеси, налагодження міжнародних зв'язків, міграційні процеси, збройний конфлікт в сукупності з багатонаціональним та етнорелігійним складом населення України, надають додаткової актуальності дослідженню складу злочинів, вчинених на ґрунті ненависті. Необхідно відзначити, що для правильної кваліфікації злочинних діянь, вчинених на ґрунті ненависті, першочерговим $€$ визначення суб'єктивної сторони злочинів та ії обов'язкових ознак.

$€$ Є.Л. Стрельцов зазначає, що суб'єктивна сторона складу злочину являє собою характеристику внутрішньої сторони злочину, встановлення якої дає можливість виявити психологічне ставлення особи до вчиненого нею суспільно небезпечного діяння та його наслідків. Саме суб'єктивна сторона становить основну частку доказової діяльності і тим самим викликає основні дискусії між сторонами в кримінальному процесі [2].

Юридичними ознаками суб'єктивної сторони складу злочину є вина, мотив, мета та емоційний стан особи під час вчинення злочину. Основною та обов'язковою ознакою будь-якого складу злочину $є$ вина, а факультативними ознаками, які набувають обов'язковості в тому разі, якщо вони вказані в диспозиції статті як обов'язкові ознаки конкретного злочину, є: мотив, мета та емоційний стан.

Для визначення певних особливостей суб'єктивної сторони злочинів проти життя та здоров'я особи, вчинених на ґрунті ненависті, варто проаналізувати чинне кримінальне законодавство. Так, законодавець до злочинів, вчинених на ґрунті ненависті відносить злочини, що вчиняються з мотивів расової, національної чи релігійної нетерпимості.

Встановлення вини у формі умислу чи необережності при вчиненні злочину можливе відносно всіх елементів об'єктивної сторони конкретного складу злочину. Так, у диспозиціях норм досліджуваних злочинів зазначені обов'язкові ознаки суб'єктивної сторони. Вину у формі умислу передбачено у диспозиціях таких норм: п. 14 ч. 2 ст. 115 «Умисне вбивство», ч. 2 ст. 121 «Умисні тяжкі 
тілесні ушкодження», ч. 2 ст. 122 «Умисні тілесні ушкодження середньої тяжкості», ч. 2 ст. 126 «Побої та мордування», ч. 2 ст. 127 «Катування», ч. 2 ст. 129 «Погроза вбивством» Кримінального кодексу України [3]. Але вид умислу у даних диспозиціях не зазначається.

Наступною ознакою суб'єктивної сторони є мета, тобто уявлення про бажаний результат, до якого прагне особа і який визначає спрямованість їі злочинного діяння. Вона $€$ характерною ознакою умисних злочинів, що вчиняються з прямим умислом. Визначити, яку конкретну мету переслідував суб'єкт злочину можливо лише при ретельному аналізі складу вчиненого злочину та виявленні його елементів і всіх обставин справи.

Щодо мотиву злочину, то це те, що спонукає людину до поставлення тих чи інших цілей, тобто внутрішні чинники, що викликають у особи рішучість вчинити суспільно небезпечну дію (бездіяльність) і керують нею при вчиненні цієї дії (бездіяльності). Мотив є обов'язковою ознакою суб'єктивної сторони складу злочину у тих випадках, коли він прямо вказаний у диспозиціях кримінального закону. В досліджуваних злочинах мотив виступає в якості ознаки, наявність якої утворює кваліфікований склад злочину.

Злочини на ґрунті ненависті є кримінально караними діяннями, вчиненими на основі упереджень щодо конкретної групи осіб. Мотив упередження можна визначити як упереджене негативне судження, нетерпимість або ненависть, спрямовані проти певної групи осіб. Цю групу повинна об'єднувати спільна ознака, наприклад, расова або етнічна приналежність, релігія, національність або будь-яка інша основна характеристика.

Суб'єкт злочину своїми діями прагне продемонструвати те, що потерпілий $\epsilon$ неповноцінною особою через його приналежність до конкретної раси, нації (національності) чи етнічної групи або релігії (віросповідання) та внаслідок цього виявляє свою упередженість та ненависть до нього.

Наявність мотиву нетерпимості має важливе значення при визнанні поведінки суб'єкта протиправною та впливає на кваліфікацію самого злочинного діяння. Таким чином, основною ознакою суб'єктивної сторони, за якою і виділяють досліджувану групу злочинів на ґрунті ненависті, $є$ мотив їх вчинення - расова, національна чи релігійна нетерпимість.

Чинним кримінальним законодавством у досліджуваних злочинах передбачені лише такі захищені ознаки як: раса, національність та релігія. На нашу думку, перелік захищених ознак необхідно узгодити з реальними тенденціями сьогодення.

Так, за 2018 рік Національною поліцією України подано звіт до ОБСє про кількість злочинів/інцидентів на ґрунті ненависті за різними ознаками. Відповідно до зафріксованих даних, значну кількість становлять злочини на ґрунті расизму і ксенофобії, релігії, антисемітизму, які належать до захищених ознак вже закріплених в кримінальному законодавстві. В той же час незалежними спостерігачами зафіксовано, що найбільшу кількість злочинів вчинено за ознаками сексуальної орієнтації та гендерної ідентичності [4]. Це свідчить про те, що чимала частина злочинів була кваліфікована або 3 хуліганських мотивів або як простий склад злочину, так як дана категорія осіб не підлягає захисту за кримінальним законодавством за мотивом упередження. 
Оскільки в Україні $є$ представники ЛГБТ-спільноти і через їх приналежність вони піддаються насильницьким діям з мотивів упередження, то для захисту прав і свобод представників ЛГБТ-спільноти та забезпечення толерантності і недискримінації, вважаємо за необхідне закріпити ознаки сексуальної орієнтації та гендерної ідентичності в кримінальному законодавстві як обставини, що обтяжують покарання.

Висновки. Отже, злочинам на ґрунті ненависті притаманні такі особливості: по-перше, це винне протиправне діяння, яке становить склад злочину, передбаченого кримінальним законодавством; по-друге, нетерпимість щодо конкретної ознаки людини стає мотивом для вчинення злочинного діяння стосовно неї. Обов'язковою ознакою суб'єктивної сторони злочинів проти життя та здоров'я особи, вчинених на ґрунті ненависті $є$ вина у формі умислу. Мотив вчинення досліджуваних злочинів характеризується трьома видами нетерпимості: расової, національної та релігійної. При цьому для кваліфікації злочинних діянь слід виявити наявність одного виду: або расової, або національної, або релігійної нетерпимості. Доречно було б додати до переліку захищених ознак сексуальну орієнтацію та гендерну ідентичність для захисту представників цих вразливих груп.

\section{Список використаних джерел:}

1. Конституція України (Закон України). № 254к/96-ВР. (1996). Вилучено 3 https://zakon.rada.gov.ua/rada/show/254к/96-вp.

2. Стрельцов, Є. Л. (2013). Суб'єктивна сторона злочину. Вісник Асоціації кримінального права України, (1(1)), 160-170.

3. Кримінальний кодекс України (Закон України). № 2341-III. (2001). Вилучено 3 https://zakon5.rada.gov.ua/laws/show/2341-14/page.

4. OSCE ODIHR Hate crime reporting. (2018). Вилучено з http://hatecrime.osce.org/ukraine.

\section{ТРУДОВА МІГРАЦІЯ: ПРОБЛЕМА СЬОГОДЕННЯ}

Горб Олександра Сергіївна

Полтавський юридичний інститут Національного юридичного університету імені Ярослава Мудрого

\section{Науковий керівник:}

Сидоренко А.C. кандидат юридичних наук, доцент

Полтавський юридичний інститут

Національного юридичного університету імені Ярослава Мудрого

УKPÄ̈HA

Сучасна Україна характеризується політичною та економічною нестабільністю, що в свою чергу призводить до збільшення потоків трудової міграції. Саме через збільшення потоків міграції з України виникає проблема забезпечення ринку праці високваліфікованими працівниками, що в свою чергу 
призводить до призупинення та занепаду підприємств а це тягне за собою ненадходження до державного бюджету коштів та небажання співпраці інвесторів з Україною. Викладене обумовлює актуальність обраної тематики дослідження.

Вказана проблематика стала предметом вивчення ряду вчених, зокрема: як: О. В. Астахова, М. М. Вівчарик, С. Ксалс, О. А. Малиновська, М. Ю. Приз, І. В. Ховрах, та інші.

Міграція населення - переміщення людей (мігрантів) через кордони тих чи інших адміністративно-територіальних одиниць зі зміною місця проживання назавжди або на більш-менш тривалий час [4]. В свою чергу міграція поділяється на внутрішню та міжнародну міграцію.Так, на думку С. Ксалс внутрішня міграція - рух з одного ареалу (провінції, округу чи муніципалітету) в інший в межах однієї країни, а міжнародною - перетин кордонів, які відділяють одну з близько 200 існуючих у світі держав від іншої, вважаючи при цьому міграцією тільки переселення на певний період часу, мінімально на півроку чи рік [5].

Слід розрізняти поняття міграції та трудової міграції. Термін „трудова міграція" визначають як переміщення особи з метою тимчасового працевлаштування, що супроводжується перетинанням державного кордону (зовнішня трудова міграція) або меж адміністративно-територіальних одиниць України (внутрішня трудова міграція) [4].

Відповідно до ЗУ “Про зовнішню трудову міграцію" : трудовий мігрант громадянин України, який здійснював, здійснює або здійснюватиме оплачувану діяльність у державі перебування, не заборонену законодавством цієї держави[1]. Тому працевлаштування - $€$ обов'язковою умовою трудової міграції. Різке зростання міграційних трудових потоків українців спостерігається у 2013 році коли вияв нестабільності держави та невпевненості в завтрашньому дні зашкалював. Зріст трудової міграції в 2013 році пов'язаний 3 погіршенням економічної ситуації, падінням курсу національної валюти а також з військовими діями.

Головними причинами, які спонукають громадян шукати роботу за кордоном є:

- незадоволення рівнем заробітної плати в Україні;

- відсутність роботи за фахом та за місцем проживання;

- невпевненість в завтрашнім дні.

За даними Мінсоцполітики на кінець 2018 року за кордоном працювали 3,2 млн українців, із яких короткострокові мігранти складають $48,5 \%$ від загалу, а довгострокові мігранти, складають близько 35-40\% від загальної кількості[6].

Потоки трудових мігрантів спрямовані в основному до сусідніх країн Польща, Російська федерація, Чеська республіка, та до країн 3 привабливішими умовами - Італія, Іспанія , Німеччина.

Найбільший потік трудової міграції відбувається на Польщу. На сьогодні Польща $є$ основною сприятливою країною для трудових мігрантів з України, так як потреба ринку праці в Польщі зростає, за рахунок відкриття нових вакантних місць, вищою заробітною платою, наявністю сприятливим для тимчасового (до 6 місяців упродовж року) працевлаштування іноземців законодавством, територіальною та культурною близькістю. 
На сьогоднішній день згідно з дослідженням середній вік українського мігранта в Польщі становить від 20 до 50 років, причому 2/3 з них чоловіки. Хоча в Іспанії та Італії більшість трудових мігрантів - жінки.

Крім того, за данними Мінсоцполітики , серед працевлаштованих за кордоном громадян України у 2018 році третина раніше працювали на транспорті, 10\% - у переробній промисловості та 10\% - на будівництві[7].

Зазвичай трудові мігранти закордоном працюють: чоловіки - в галузі будівництва та перевезення, жінки - обслуговування.

Гендерний розподіл українських трудових мігрантів наступний: чоловіки $66 \%$ та жінки - $34 \%$. Кількість сільських жителів перевищує тих, хто приїхав із міста (відповідно 54 \% проти $46 \%$ ). За віковими групами трудові мігранти розподіляються таким чином. Близько чветрі - мігранти віком 40 - 49 років, п'яту частину становлять мігранти віком 30 - 34 роки, по $15 \%$ припадає на групи віком 25 - 29, 35 - 39 та 50 - 59 років. Таким чином середній вік становить 37 років. $65 \%$ трудових мігрантів мають повну загальну середню освіту, 30 \% вищу освіту (проте половина з них лише базову або неповну вищу освіту) [3].

Також однією із причин збільшення потоків трудової міграції $€$ рівень заробітної плати в Україні та в державах за кордоном. Заробітки трудових мігрантів, які $€$ як мінімум в три а то і в п'ять разів вищими, ніж в Україні. Високий рівень заробітної плати в іноземних державах має і позитивні наслідки для України. По-перше, заробітчани отримують роботу, по-друге, зменшується напруга на вітчизняному ринку праці, і по-третє, вони здійснюють перекази зароблених коштів своїм родичам у економіку України.

За даними обстеження середньомісячний заробіток одного трудового мігранта становив 930 доларів, що майже втричі більше ніж у середньому на одного штатного працівника, зайнятого в економіці України - 330 доларів (в 2008 р. - 817 доларів) [3].

Найвищий рівень трудової міграції спостерігається в західних регіонах України, на другому місці - центральні та східні регіони. Така ситуація щодо трудової міграції в західних регіонах повязується з територіальною близькістю до державного кордону та історичні зв'язки. Лідером за кількістю трудових мігрантів є Закарпатська область. Зазвичай західні регіони виїзжають до Польщі, Чехії , Словаччини, Німеччини , а центральні, східні, північні та південні регіони - Російська Федерація, Білорусія тощо.

Нашій державі для того щоб зупинити потік працездатного економічноактивного населення потрібно створити сприятливі умови. Найголовнішими умовами є: робочі місця для працездатного населення, заробітна плата на рівні європейської. Міграційна політика України має розроблятися разом із стратегією економічного розвитку країни, та спрямовуватись на створення кращих умов для інвесторів на відновлення довіри до влади та забезпечення високих стандартів людського життя.

Отже, питання трудової міграції $є$ актуальним і важливим на сьогоднішній день. Саме економічна та політична нестабільність відіграють вважливу роль в збільшені рівня трудових мігрантів з України. Основними факторами які впливають на рівень трудової міграції з України є: розмір заробітної плати, відсутність робочих місць, неправильна міграційна політика держави та політична ситуація в Україні. Для того аби запобігти збільшенню міграційних процесів українській владі потрібно більше уваги приділяти 


\section{Список використаних джерел:}

1. Про зовнішню трудову міграцію (Закон України). (2015). Вилучено 3 https://zakon.rada.gov.ua/laws/show/761-19

2. В., Капітан. (2012). Трудова міграція як аспект проблеми зайнятості в Україні (с. 474-481).

3. Звіт щодо методології організації проведення та результатів модульного вибіркового обстеження з питань трудової міграції в Україні / Міжнародна організація праці. Група технічної підтримки з питань гідної праці та Бюро МОП для країн Центральної та Східної Європи (2013). Будапешт.

5. Валентей, Д. И. (ред.). (1985). Демограффічнй енциклопедичний словник

6. Каслз, С. (2001). Глобальні тенденції і проблеми. Міжнародна міграція на початку XXI століття: әлобальні тенденції і проблеми. Міжнародний журнал соціальних наук № 032. (c. 27-42).

7. Позняк, О. (2019). Українці за кордоном: чи зменшиться кількість трудових мігрантів у 2019. Вилучено з https://voxukraine.org/uk/connector/ukrayintsi-za-kordonom-chi-zmenshitsyakilkist-trudovih-migrantiv-u-2019/

8. Дещиця, А. (2018). У Польщі працює і живе більше 1 мільйона українців. Вилучено 3 https://kr24.com.ua/news/polscha-vidnjala-v-ukrajini-najtsinnishe

\section{ЩОДО МІЖНАРОДНОЇ ПРАВОСУБ’ЄКТНОСТІ НАЦІЙ}

\section{Пархуць Владислав Дмитрович \\ студент 5 курсу \\ Дніпровський національний університет ім. Олеся Гончара \\ УКРӒ̈̈А}

Правосуб'єктність націй, які боряться за незалежність, як і правосуб'єктність держав, носить об'єктивний характер, тобто існує незалежно від будь-чиєї волі. Сучасне міжнародне право підтверджує і гарантує право народів на самовизначення, включаючи право на вільний вибір і розвиток свого соціально-політичного статусу.

Принцип самовизначення народів $€$ одним 3 основних принципів міжнародного права, його становлення припадає на кінець XIX - початок XX ст.

3 прийняттям Статуту ООН право нації на самовизначення остаточно завершило своє юридичне оформлення в якості основного принципу міжнародного права [1]. Декларація про надання незалежності колоніальним країнам і народам 1960 р. конкретизувала й розвинула зміст цього принципу [2]. Найбільш повно його зміст було сформульовано в Декларації про принципи міжнародного права 1970 р., де говориться: «Всі народи мають право вільно визначати без втручання ззовні свій політичний статус і здійснювати свій економічний, соціальний і культурний розвиток, і кожна держава зобов'язана поважати це право в відповідно до положень Статуту ООН» [3].

У сучасному міжнародному праві $€$ норми, що підтверджують правосуб'єктність націй, що боряться за незалежність. Нації, що борються за створення незалежної держави, знаходяться під захистом міжнародного права; вони об'єктивно можуть застосовувати заходи примусу щодо тих сил, які перешкоджають отриманню нацією повної міжнародної правосуб'єктності, 
оформлення в державу. Але застосування примусу - не єдине і, в принципі, не головний прояв міжнародної правосуб'єктності націй. Суб'єктом міжнародного права може бути визнана лише та нація, яка має свою політичну організацію, самостійно здійснює квазідержавні функції.

Інакше кажучи, нація повинна мати наближену до державної фоому організації: народний фронт, зачатки органів влади і управління, населення на контрольованій території і т.д.

Необхідно враховувати, що міжнародно. правосуб'єктністю можуть володіти (і мають) не всі, а лише обмежене число націй - нації, які не мають держави, але які прагнуть до їх створення відповідно до міжнародного права.

Таким чином, практично будь-яка нація потенційно може стати суб'єктом правовідносин щодо самовизначення.

В даний час особливого значення набуває інший аспект права націй на самовизначення. Сьогодні мова йде про розвиток нації, яка вже свідомо визначила свій політичний статус. У нинішніх умовах принцип права націй на самовизначення повинен гармонізуватись, узгоджуватися 3 іншими принципами міжнародного права i, зокрема, з принципом поваги державного суверенітету і невтручання у внутрішні справи інших держав. Іншими словами, потрібно говорити вже не про право всіх націй на міжнародну правосуб'єктність, а про право нації, що отримала свою державність, розвиватися без втручання ззовні.

Нація, яка бореться за незалежність вступає в правовідносини з державою, яка контролює ці території, з іншими державами і націями, міжнародними організаціями. Беручи участь в конкретних міжнародних правовідносинах, вона набуває додаткові права і захист.

Розрізняють права, якими нація вже володіє (вони випливають 3 національного суверенітету), і права, за володіння якими вона бореться (витікають з державного суверенітету).

Правосуб'єктність нації, яка бореться за незалежність включає в себе комплекс наступних основних прав: право на самостійне волевиявлення; право на міжнародно-правовий захист і допомогу з боку інших суб'єктів міжнародного права; право на участь в міжнародних організаціях i конференціях; право брати участь в створенні норм міжнародного права і самостійно виконувати прийняті на себе міжнародні зобов'язання.

Таким чином, суверенітет нації, яка бореться за незалежність, характеризується тим, що він не залежить від визнання ії̈ суб'єктом міжнародного права з боку інших держав; права такої нації охороняються міжнародним правом; нація від свого імені вправі застосовувати примусові заходи проти порушників ії̈ суверенітету.

\section{Список використаних джерел:}

1. Статут Організації Об'єднаних Націй і Статут Міжнародного Суду (1945). Вилучено з https://zakon.rada.gov.ua/laws/main/995_010.

2. Декларація про надання незалежності колоніальним державам та народам (1960). Вилучено 3 https://zakon.rada.gov.ua/laws/main/995_280.

3. Декларація про принципи міжнародного права, що стосуються дружніх відносин та співробітництва між державами відповідно до Статуту Організації Об'єднаних Націй (1970). Вилучено 3 https://zakon.rada.gov.ua/laws/main/995_569. 


\section{ЩОДО ПОНЯТТЯ НОВОВИЯВЛЕНИХ ОБСТАВИН, ЇХ ВІДМЕЖУВАННЯ ВІД НОВИХ ОБСТАВИН}

Возняковська Крістіна Анатоліївна

доктор юрид. наук, доцент кафедри цивільно-правових дисциплін

Чернівецький юридичний інститут

Національного університету «Одеська юридична академія»

УКРАÏHA

Після набрання законної сили судового акту може з'ясуватися, що в момент прийняття судом рішення, ухвали або постанови існували обставини, що мають істотне значення для справи, але які не були і не могли бути відомі однієї зі сторін або обом сторонам. Іноді виявляється, що в судовому рішенні є суттєві відмінності по тій причині, що ані суд, ані особи, які приймали участь справі, не знали і не могли знати про такі обставини. Саме для перегляду судових рішень, які прийняті в таких ситуаціях і існує інститут перегляду судових актів за нововиявленими або виключними обставинами.

Даний перегляд $€$ абсолютно окремою стадією господарського процесу, яка покликана сприяти дотриманню принципу законності та захисту прав і інтересів суб'єктів господарювання.

Згідно Постанови Пленуму Вищого господарського суду "Про деякі питання практики перегляду рішень, ухвал, постанов за нововиявленими обставинами" від 26.12.2011 року №17[3], до нововиявлених обставин відносяться матеріально-правові фракти, на яких ґрунтуються вимоги і заперечення сторін, а також інші фракти, які мають значення для правильного вирішення спору або розгляду справи про банкрутство. Необхідними ознаками існування нововиявлених обставин $\epsilon$ одночасна наявність таких 3-х умов: по-перше, їх існування на час розгляду справи, по-друге, те, що ці обставини не могли бути відомі заявникові на час розгляду справи, по-третє, істотність даних обставин для розгляду справи (тобто коли врахування їх судом мало б наслідком прийняття іншого судового рішення, ніж те, яке було прийняте). Нововиявлені обставини за своєю юридичною суттю $є$ фактичними даними, що в установленому порядку спростовують факти, які було покладено в основу судового рішення. Ці обставини мають бути належним чином засвідчені, тобто підтверджені належними і допустимими доказами. Не може вважатися нововиявленою обставина, яка ґрунтується на переоцінці тих доказів, які вже оцінювалися господарським судом у процесі розгляду справи.

Тобто, само по собі прийняття заяви про перегляд судового рішення за нововиявленими обставинами не означає обов'язкового скасування чи зміни рішення, що переглядається. Результат перегляду повинен випливати з оцінки доказів, зібраних у справі, і встановлення господарським судом на основі цієї оцінки наявності або відсутності нововиявлених обставин, визначення їх істотності для правильного вирішення спору або розгляду справи про банкрутство. Господарський суд вправі змінити або скасувати судове рішення за нововиявленими обставинами лише за умови, що ці обставини впливають 
на юридичну оцінку обставин, здійснену судому судовому рішенні, що переглядається.

Згідно з юридичною енциклопедією Шемчушенка Ю.С., нововиявлені обставини - це юридичні факти, що існували на момент розгляду справи в суді і мали істотне значення для ії правильного вирішення, але не були і не могли бути відомі ні суду, ні заінтересованим особам, спричинили порушення прав i законних інтересів фізичних або юридичних осіб, а будучи виявленими після набуття судового рішення законної сили, виступають підставами для їх перегляду у кримінальних, цивільних чи господарських справах [5].

Аналізуючи правову літературу, можна знайти різні точки зору щодо поняття нововиявлених обставин, зокрема.

А.Ф. Клеймам зазначає, що - абсолютно нова фактична обставина, новий юридичний фракт, що не стосується нового доказу у справі [1]. Є.М. Ломоносова вважає, що це завжди істотні для справи факти об'єктивної дійсності, що існували в період первинного провадження у справі і ухвалення судового акта, які не були враховані в ньому за невідомості їх суду і заявникові з причин, від них не залежних, а не в результаті помилки суду. Це фракти, що відкриваються після набуття актом правосуддя законної сили і можуть вплинути на його законність і обґрунтованість, істинність, на можливість захисту і здійснення передбачених прав і інтересів, що охороняються [2].

Так, Господарський Суд Дніпропетровської області у справі № 904/9306/17 вирішив задовільнити заяву ТОВ "АТБ-Маркет" про перегляд рішення Господарського суду Дніпропетровської області від 22.01.2018 у справі № 904/9306/17 за нововиявленими обставинами, оскільки, розглянувши подану заяву та дослідивши подані докази, встановив, що в даному випадку нововиявленою обставиною $є$ постанова Центрального апеляційного господарського суду від 15.01.2019 у справі № 904/6226/17 [4].

Отже, нововиявленими обставинами у господарському судочинстві можна вважати - ті дані про фракти, які існували в момент здійснення провадження по справі і які мають істотне значення для вирішення справи, але були виявлені і встановлені після набрання законної сили рішень, постанов та ухвал господарського суду у зв'язку з невідомостю про них суду та заявнику.

\section{Список використаних джерел:}

1. Клейман, А.Ф. Советский гражданский процесс. М., 1954. - 407с.

2. Ломоносова, Е. М. (1970). Пересмотр гражданских дел по вновь открывшимся обстоятельствам (Автореф. дис. ... канд. юрид. наук.) Харьков.

3. Про деякі питання практики перегляду рішень, ухвал, постанов за нововиявленими обставинами. Постанова Пленуму Вищого господарського суду від 26.12.2011 року №17 [Електронний ресурс] - Режим доступу: https://zakon.rada.gov.ua/laws/show/v0017600-11

4. Рішення Господарського суду Дніпропетровської області від 16.04.2019 у справі № 904/9306/17. Вилучено $3 \mathrm{http}: / /$ reyestr.court.gov.ua/Review/81267072

5. Юридична енциклопедія (1998). (ред. Ю. С. Шемшученко [та ін.] ; НАН України, Ін-т держави і права ім. В.М.Корецького. К. : Вид-во "Українська енциклопедія" ім. М.П.Бажана. 


\section{SECTION XIII. HISTORY}

\section{АКТУАЛЬНІ ПИТАННЯ ГУРТКОВОЇ РОБОТИ У СУЧАСНИХ НАУКОВИХ РОЗРОБКАХ}

Варсан-Карапаскал Вікторія Вікторівна

здобувач вищої освіти фракультету української філології та соціальних наук Ізмаїльський державний гуманітарний університет

НАУКОВИЙ КЕРІВНИК:

Гончарова Наталія Олександрівна канд. істор. наук, доцент, доцент кафедри української і всесвітньої історії та культури Ізмаїльський державний гуманітарний університет УКРÄ̈HA

На сучасному етапі суспільство ставить перед системою освіти і виховання низку завдань, серед яких важливе місце посідає соціалізація молоді. Ефективній реалізації зазначеного завдання сприяє гурткова робота. Вивченню різноманітних її аспектів присвячено чимало праць, що безумовно підтверджує інтерес до неї з боку фахівців. Метою статті $є$ аналіз розвідок сучасних дослідників відповідної проблематики для визначення основних напрямів профессійних пошуків.

Положенням «Про позашкільні навчальні заклади» визначається: гурток це об'єднання вихованців, учнів і слухачів відповідно до їх нахилів, здібностей, інтересів до конкретного виду діяльності з урахуванням їх віку, психофізичних особливостей, стану здоров'я. Відповідно до основних завдань гуртка відносимо поглиблення набутих на уроках знань, розвиток інтересів і здібностей школярів тощо [5].

Наявну літературу доцільно структурувати. Значну частину праць присвячено гуртковій роботі зі студентами. Зокрема, в роботі О. Білостоцької висвітлені особливості фрормування професійних, морально-вольових і пізнавальних якостей майбутніх учителів у контексті діяльності студентського наукового гуртка. Авторка приділяє увагу завданням і змісту роботи наукових гуртків, характеризує організаційні принципи їх діяльності. Насамкінець О. Білостоцька наголошує, що правильно організована діяльність студентських наукових гуртків сприяє оволодінню спеціальністю, формуванню здібностей застосовувати теоретичні знання на практиці і в житті, розширенню наукової ерудиції і теоретичного кругозору [1]. І. Трефраненко, О. Хухліна у своїй розвідці презентують основні форми науково-дослідної роботи в межах студентського наукового гуртка. Автори зазначають, що вдало дібрані форми гурткової діяльності сприяють розвитку творчого й аналітичного мислення, розширенню наукового світогляду. Учасники гуртка поглиблюють власні знання з обраної ними наукової галузі, отримують необхідні для подальшої професійної і наукової роботи навички [7]. 
На переконання І. Воронової, О. Попович, метою гурткової роботи на перших курсах $€$ зацікавлення студента творчістю, залучення до дослідницького пошуку в різноманітних сферах. Автори до головних завдань гурткової роботи на першому та другому курсах відносять: поглиблення знань із дисциплін загальноосвітньої та фундаментальної підготовки за фахом, розширення ерудиції студента, визначення його наукових уподобань [3].

Інший аспект, досить широко представлений у працях науковців, це діяльність учнівських гуртків та позанавчальна гурткова діяльність. Так, у статті Н. Бойко розглянуто процес виховання дітей в умовах гурткової діяльності на базі дошкільних навчальних закладів. Дослідниця визначає спрямування i структурування гуртків, резюмуючи: гурткова робота в дошкільному закладі сприяє ефективному формуванню життєво компетентної, творчо спрямованої особистості через своєчасне виявлення здібностей і нахилів дітей. Окремо Н. Бойко відзначає, що гурткова робота безперечно активізує розвиток однієї із базових якостей - креативності [2]. Л. Чистякова аналізує види навчальних програм із позашкільної освіти та досліджує рівні гуртків. Авторка переконана, що надважливою умовою організації гуртка $є$ створення таких психологопедагогічних умов, за яких дитина з перших днів перебування у гуртку буде спроможна реалізувати мінімум товариських очікувань [8]. Крім того, Л. Чистякова наголошує: робота у гуртку має сприяти розвитку колективізму, взаємо- і самоповаги.

Т. Сорока, Б. Струганець аналізують нормативно-правову основу позашкільної освіти, розкривають принципи позашкільної освіти, визначають вимоги до сучасного гурткового заняття. Фахівці упевнені, що система позашкільної освіти формується як соціальний інститут, котрий поєднує шкільний освітній простір та соціальне середовище. Саме в її контексті молодь вчиться транслювати адекватні приклади поведінки і діяльності, ціннісні орієнтири, накопичує власний соціальний досвід [6]. У статті О. Гуренко, О. Величко розглянуто принципи, функції й етапи виховання культури міжнаціонального спілкування дітей-підлітків в умовах гурткової роботи в позашкільних навчальних закладах. У висновку автори відзначають, що відповідне доповнення змісту роботи гуртків позашкільних навчальних закладів етнокультурною тематикою здатне уможливити процес виховання культури міжетнічного спілкування молоді. Крім того, вони стверджують, що цей процес включає 4 етапи: діяльнісний, ментальний, оцінний, статусний [4].

Отже, проведений аналіз дозволяє відзначити зростання інтересу науковців до різних аспектів гурткової роботи у закладах загальної середньої і вищої освіти. До перспективних напрямів подальших досліджень варто віднести вивчення специфіки діяльності гуртків історико-краєзнавчого спрямування.

\section{Список використаних джерел:}

1. Білостоцька, О.В. (2016) Науковий гурток як засіб формування професійних якостей майбутніх учителів. Збірник наукових праць Херсонського державного університету. Педагогічні науки, Вип. 72 (1), 86-91.

2. Бойко, Н.В. (2015) Організаційно-педагогічні умови використання гурткової діяльності в дошкільних навчальних закладах. Вісник Черкаського університету, (10 (343)), 19-26. 
3. Воронова, І.І., Попович, О.М. (2018) Розвиток здібностей студентів у процесі гурткової роботи. Предметний гурток: задачі, форми роботи, облік роботи та звітність. Збірник праць. Дніпро: Дніпровський міський базовий технікум зварювання та електроніки імені Є.О. Патона, 55-59.

4. Гуренко, О.І., Величко, О.М. (2012) Особливості організації гурткової роботи позашкільних навчальних закладів з виховання культури міжетнічних стосунків. Педагогічна освіта: теорія і практика. Збірник наукових праць, (12), 478-483.

6. Про позашкільну освіту (Закон України). № 1841-III зі змінами. (2000). Вилучено 3 https://zakon.rada.gov.ua/laws/show/1841-14.

7. Сорока, Т.П., Струганець, Б.В. (2016) Актуалізація можливостей позашкільної освіти в соціалізації підлітка. Наукові записки. Серія: педагогіка, (2), 275-281.

8. Трефаненко, І.В., Хухліна, О.С. (2017) Студентський науковий гурток як вид науководослідної роботи студентів. Вісник ВДНЗУ «Українська медична стоматологічна академія». Актуальні проблеми сучасної медицини, т. 17, Вип. 1 (57), 278-281.

9. Чистякова, Л. (2015) Особливості організації гуртка з трудового навчання. Наукові записки. Серія: Проблеми методики фрізико-математичної і технологічної освіти, Вип. 8 (1), 107111.

\section{DOI 10.36074/13.12.2019.v4.02}

\section{ДО ПИТАННЯ ПРО ВЖИВАННЯ УКРАЇНСЬКОЇ МОВИ У КІНЕМАТОГРАФІ НАПРИКІНЦІ 1980-х pp.}

\section{Абакумова Вікторія Іванівна}

д-р. іст. наук, професор Глухівський національний педагогічний університет імені Олександра Довженка УКРӒ̈НА

Соціальні перетворення другої половини 1980-х років докорінно змінили суспільно-політичну ситуацію в Україні. Відбувся злет національної самосвідомості. В нових умовах влада вимушена рахуватися з процесом пожвавлення розвитку національної самосвідомості і національної культури. 3 метою забезпечення реалізації Закону УРСР "Про мови в Українській РСР" Рада Міністрів Української РСР 12 лютого 1991 р. схвалила Державну програму розвитку української мови та інших національних мов в Українській РСР на період до 2000 року [2]. Так ще за часів Союзу в суспільстві розпочався процес завоювання державного статусу українською мовою. Виокремимо особливості цього процесу в сфрері кіноіндустрії.

По-перше, аналіз певних фрактів, подій, заходів, спрямованих на вирішення мовного питання в кіновиробництві доводить, що серйозні зрушення, головним чином, пов'язані із зверненням творчих пошуків кіномитців до української літератури і драматичної класики, історичних джерел, що залишалися не засвоєними екранним мистецтвом. Починаючи з 1988 р. дирекція кіностудії ім. О. Довженка спільно з провідними творчими працівниками і літераторами республіки проголосила програму по відродженню національного кіно, включення до неї масштабних кінопроектів про життя і творчість Тараса 
Шевченка, Івана Франка, Лесі Українки, екранізації української літературної класики, творчої реабілітації письменників України, заявки молодих українських сценаристів і режисерів. Проте така робота йшла важко. У попередній період українського ігрового кіно цей інтерес до національній культурі був втрачений, що не могло не відбитися в настроях й планах творчої молоді.

Значно динамічніше змінювалося становище в неігровому кіно. Виробництво неігрових фільмів цього періоду відрізнялось новим репертуаром - світ побачили стрічки про національну самобутність українського народу, його культуру, мову. Характерно, що збільшення кількості документальних стрічок в українському варіанту, присвячених життю України відбувається на хвилі загальнонародного інтересу до раніше заборонених тем, «білих плям» історії, громадсько-політичних рухів.

По-друге, позитивним моментом у реалізації Закону про мови стало створення на київській студії ім. О. Довженка ВТО «Сузір'я», яке здійснює дублювання українською мовою кращих вітчизняних та зарубіжних фрільмів. У 1989 р. були зроблені українські дубляжі 12 фільмів, 1990 р. - 17, а 1991-25 [3, арк.38]. При цьому, комісія по відбору кінотворів для дубляжу орієнтувалося в основному на картини для дітей і на стрічки високого ґлядацького попиту. Така діяльність підкріплювалась фінансово - згідно «Державної програми розвитку української мови та інших національних мов в Українській РСР на період до 2000 р.» збільшувались кошти для дублювання й тиражування кінофрільмів, що вироблялися за межами республіки та демонструвалися по телебаченню, в кіномережі та відеосалонах.

По-третє, надзвичайно важливим фрактором виступало впровадження державного соціально-творчого замовлення на фільми, які висвітлювали найбільш значні й активні проблеми історії України і її сьогодення. Наприклад, кількісне збільшення фільмів цієї тематики і випуск їх українською мовою у $1990-1991 \mathrm{pp}$. безпосередньо пов'язаний із програмою замовлень Міністерством культури УРСР (з 32 фільмів, замовлених міністерством у 1991 р. - 29 як україномовні) [3, арк.37].

Між тим, треба визнати, що на тлі позитивних зрушень, українською мовою продовжувала створюватися менша частка фільмів. А тому перші здобутки в опануванні українським кінематографом національної мови виглядають скромно. Наприклад, на кіностудії імені О.Довженка 1990 р. лише 5 україномовних із 13 прокатних кінофільмів і 7 україномовних телестрічок; 1991 р. - 9 україномовних фільмів. На Одеській кіностудії за останні 20 років вийшли лише 3 фрільми в українському варіанті. Незадовільним можна вважати мовний статус фільмів молодіжного об'єднання «Дебют»: зі 21 - тільки 5 вийшли в українському варіанті [3, арк.36]. Загалом наприкінці 1980-х років національний мовний статус кінопродукції реалізувався дублюванням власних стрічок українською мовою (за рахунок коштів УРСР).

Із 50 хронікально-документальних картин річної програми студії «Укркінохроніка» понад 30 були присвячені національній проблематиці та створені українськими митцями. Решта - російськомовні. Їх автори виправдовували вибір російської мови тим, що їх герої не володіють вільно українською мовою. Фільми масового екрану студії «Київнаукффільм» взагалі 
створювалися переважно російською мовою, так як виробництво науковопопулярних стрічок значною мірою асигнувалося з союзного бюджету. Але цікаво, що всі анімаційні фільми, що створювалися в республіці (13-18 назв на рік) мали основним український варіант [3, арк.36-38]. Однак, тираж цих фільмів надходив у кіномережу республіки від союзного кінопрокату вже російською мовою. В умовах ринкових відносин загострилися і проблеми, пов'язані з прокатом україномовних фрільмів, від яких масовий глядач за роки нігілістичного ставлення до власної мови і національної культури встиг відзвичаїтись.

На незацікавленості окремих кінорежисерів в освоєнні національної тематики і створенні фрільмів в українському оригіналі певною мірою позначався диктат комерційного підходу до кіно, умови продажу картин на всесоюзному ринку. Наприклад вартість ліцензії на фрільми українських студій були значно нижчими за кінопродукцію центральних і зарубіжних кіностудій. Середня вартість ліцензії за одну копію фрільмів українських кіностудій дорівнювала 605 крб., центральних кіностудій -1115 крб., зарубіжних - 4000 крб [1, арк.104]. 3 кінця 1990 р. відійшла в минуле практика, коли при прийомі фільмів республіканських студій для союзного кінопрокату вартість російськомовних дубляжів оплачувало Держкіно СРСР. Тепер дублювання створених національною мовою кінострічок для союзного екрану мало здійснюватися за рахунок студій або коштів республіки, що одразу зумовило відмову від україномовної творчості багатьох кіномитців.

Безумовно, багато перешкод зумовлено об'єктивними чинниками, проте не можна заперечувати людський фактор. Так, неприглядне становище, яке склалося з випуском україномовних фрільмів на кіностудіях України у 1980-ті рр. - мало коріння не лише в інерції впливу адміністративно-командної системи, а й у світоглядних позиціях багатьох кіномитців, їх слабкій обізнаності з історією і культурою України, народною творчістю, прагненням режисерів до широкого залучення у свої фільми акторів-зірок з Москви і Ленінграду, які не володіли українською мовою.

Отже, розгляд особливостей процесу впровадження української мови в галузь кіновиробництва свідчить, що певні здобутки отримані ще в період, який передував незалежності України. Разом з тим, загальна ситуація у сфері культури залишалася невирішеною. Ключовий тягар проблем накопичився у свідомості. Наочним $€$ фракт вирішальної ролі державної підтримки кіновиробництва за умов переходу кінематографії на ринкові відносини, зокрема фрінансування з бюджету республіки виробництва фрільмів.

\section{Список використаних джерел:}

1. Відомчий архів Міністерства культури України, ф.5116, оп.19, спр.3143.

2. Про Державну програму розвитку української мови та інших національних мов в Українській РСР на період до 2000 року (Постанова Ради Міністрів УРСР) N 41 від 12.02.1991 р. Вилучено 3: http://zakon.rada.gov.ua

3. Центральний державний архів вищих органів влади і управління України, ф.5116, оп.19, спр.3069. 


\section{ЕВОЛЮЦІЯ ЖІНОЧИХ ОБРАЗІВ У ПОСТМОДЕРНІЙ МОДІ США 40-70 PP. XX CT.}

Дутканич Віра Сергіївна

здобувач вищої освіти історичного факультету Львівський національний університет імені Івана Франка

УKPÄ̈̈A

У XX cт. у час швидких змін та нестабільності, створені образи модного світу все частіше ставали прямим викликом традиційним поняттям статусу, гендеру та етносу. На Заході уявлення про витонченість та елегантність уособлювалось в "образі Леді", пані з вищого прошарку, яка була еталоном для всіх жінок. Економіст та соціолог Торстейн Веблен, який творив наприкінці XIX - на початку XX ст. говорив, що "Леді - це невід'ємна ознака успішного одруженого чоловіка, яка повинна підтримувати його високий статус" [1]. İ̈̈ ж особистий статус був міражем, що зазвичай залежав від статків ії̈ батька чи чоловіка. Через війну мода зазнала значних змін. Жінкам стало ніколи думати про макіяж і поповнення свого гардеробу. Під час окупації Франції деякі модні доми залишались відкритими, про те ніякої інформації про нові колекції в інші країни не надходило. Через те центр моди перемістився з Парижу до НьюЙорку, де домінуючими ідеями стали простота і функціональність.

У цей час одяг значно спростився до мінімалізму у всьому. Відтепер натуральні тканини перестають використовувати для повсякденного вжитку, а жіночий одяг починають виробляти з ацетатного шовку і віскози. Неможливим стало шити блузи і сорочки з білої тканини, тому в моду ввійшли манжети i комірці. Відкриттям воєнного періоду став популярний і сьогодні стиль "мілітарі". У повоєнні роки помітно загострилися соціальні відмінності. Якщо під час війни жінки отримували можливість працювати та реалізовувати свій потенціал, то тепер дружини знову перетворилися в символ добробуту своїх чоловіків, як своєрідна вітрина для оточуючих. Ідеальна жінка, навіть якщо вона ніде не працювала і була домогосподаркою, вже рано вранці повинна була бути у всеозброєнні: з ідеальною зачіскою, на підборах і з макіяжем, стояти біля плити.

Уявлення про те, як вплинув фемінізм на моду, теж пішли не далеко. Насамперед на думку спливають корсети, від яких жінок нібито звільнила Коко Шанель. Але, по-перше, це зробила не К. Шанель, а ще Поль Пуаре, а подруге, вже хто-хто, а П. Пуаре був максимально далекий від всякого фемінізму, вважаючи жінку витонченою дрібничкою, яку потрібно декорувати [2]. Між іншим, його дружина, Деніза Пуаре ввійшла у історію як перша модель, що взяла участь у дефріле. Постать К. Шанель тут, втім, має сенс, оскільки саме вона була першою, хто почав радикально спрощувати жіночий костюм і додавати в нього чоловічі речі. Все це мало не лише практичне значення - в простих речах стало банально легше пересуватися, - а й символічний: жінка 3 суб'єкта декорування стала перетворюватися на об'єкт зі своїми запитами та вимогами [3]. А саме це - перетворення жінки з пасивного суб'єкта сексуального та соціального, в активний діючий об’єкт - і $є$ сутністю фемінізму. 
У 1940-х - 1950-х рр. американська дизайнера Клер Маккарделл також шила простий за стилем одяг, хоч і значно дешевший за моделі К. Шанель. Вона використовувала практичні матеріали, однак ії одяг здобув популярність через ефектні образи [4]. Дизайнерка черпала свої ідеї у спортивному та танцювальному стилях, створюючи одяг, який міг би одягнути будь-хто. К. Маккарделл відчула початок змін і створила лінію офріційних костюмів для жінок, які лише починали працювати і не могли дозволити собі дорогий одяг, проте їх одяг мав відповідати дрес-коду. [5]. Американський стиль, який вона створила, був зорієнтований на людину спортивну та зайняту - ту, яка йде в ногу з часом. Жінки, що знайшли у собі мужність одягнути одяг К. Шанель та К. Маккарделл повинні були розуміти, що швидше за все натраплять на осуд суспільства, яке ще не зовсім розуміло нові модні віяння, які відтепер домінували. Замість показової розкоші ці дві дизайнерки використовували прості образи і вдихали у них нову жіночність, засновану на незалежності та життєвій енергії. Післявоєнне суспільство розшукувало нове маркування статусу та смаку, цю нішу заповнила вдавана простота [6].

Модельєр Елізабет Хос у своїй книзі "Чоловіки все витримають" писала: "Я можу прямо сказати, що жінки повинні носити штани на роботу, але мої слова нічого не змінять. Навіть якщо б їм це сказала Грета Гарбо, чи Коко Шанель, чи сам Господь Бог - це б також нічого не змінило. Жінки не готові носити штани на роботу. Коли будуть готові - вони їх одягнуть. Для того, щоб жінки вибрались з корсетів знадобилась світова війна. Напевно, треба буде ще одну, щоб вони одягнули штани" [7]. Авторка була права, оскільки для тодішньої жінки було психологічно важко одягнути штани, за незначними винятками, бо вони були винятково чоловічим аксесуаром одягу. Аби штани увійшли в щоденний гардероб модниць мусіла відбутися революція у свідомості жінки та суспільства загалом. У кінці 1940-х рр. всі старання жінок-модельєрів були знищені новими ідеями Крістіана Діора, якими звернувся за натхненням до вікторіанської епохи, наново вводячи у моду модернізовані пишну спідницю та, замість колишнього корсету, вузький приталений жакет.

У 1947 р. К. Діор представив нову лінію "Corolle"/ "Королла", створивши стиль "нью лук", який наново закріплював як і диференціацію у суспільстві між бідними та багатими, так і домінування високої моди над всіма іншими стилями в одязі Це видавалось несправедливим - діорівське натхнення розкішною вікторіанською епохою, тоді як більшості не вистачало тканини для пошиття простого одягу. Пишні сукні та спідниці К. Діора спершу не найшли в США, Франції, Англії прихильників, окрім представників істеблішменту. Відомий випадок, що стався у Парижі, чітко описує соціальну напругу - на моделей, що були одягнуті у сукні від "Діор", накинулись на вулиці розлючені жінки і почали зривати з них пишні спідниці. "Нью-лук" повинен був наново розмежувати суспільство. Цей стиль ставав немов би театральною маскою на обличчі схвильованого повоєнного часу. Для частини суспільства новий, штучно створений образ, став відрадою для очей - жінки знову ставали витонченими створіннями, що балансували на шпильках і повертали відчуття екстравагантності після тяжких шести років.

Цікаво те, що у 1950-х рр. у суспільстві царювали дві крайності - $з$ одного боку, після Другої світової війни жінки довели, що можуть "перевернути гори", 
а з іншого боку - суспільство було не готове до прояву такої сильної сторони жінки. Про це й не забарились написати у своїх роботах Фердинанда Ландберг та Марінья Фарнхем "Сучасна жінка: втрачена стать" (1947р.) та Альберта Елісса "Американська сексуальна трагедія" (1954р.). Вони стверджували, що жінки використовують одяг як зброю проти чоловіків, оточуючи своє его міцною бронею з гламуру [8]. Подібні тези демонстрували негативне сприйняття нової жіночності та успіхів, яка жінка здобувала у тогочасному світі. Не дивно, що на початку 1970-х рр. феміністки так гостро виступали проти традиційної жіночності, яка, як вони вважали, деморалізує образ жінки та відволікає від важливіших завдань. Незважаючи на це вплив моди на загальні тенденції залишався вагомим. "Бумом" послугувала колекція 1966 р. Ів Сен-Лорана, який перетворив мужній смокінг у витончений жіночий "le smoking", що швидко стало символом шику для жінок, що хотіли залишатись і гламурними, i незалежними водночас [9]. Під натиском масової культури дрес-коди ставали все менш строгими та більш піддатливими до нововведень Проте навіть Ів Сен-Лоран 3 його геніальною ідеєю перетворити чоловічий костюм в улюблений предмет жіночого гардеробу не приніс потрібного ефеекту, так як суспільство було далеким від цього, і така революція була в дивину. В загальному, Ів Сен-Лоран був знаковою фрігурою у модному просторі світу. До прикладу, у 1970-х рр. він викликав одним зі своїх показів широкий суспільний резонанс, запропонувавши у новій колекції елементи повоєнної моди - широкі штани у поєднанні 3 широкоплечими піджаками, туфлі на платформі 3 маленькою шпилькою. Все це породило спогади про часи війни, і багато присутніх на показі, що пережили ці події, були обурені [10]. Все це наводить нас на думку, що мода все ж зберігає колективну пам'ять і може воскресити в пам'яті спогади про давно забуті спогади. Молодому поколінню, що не пам'ятало війни, цей стиль в одязі прийшовся до вподоби. Можна відзначити, що вже в перші два десятиліття після Другої світової війни зникає стильова єдність - паралельно існує безліч стилів, які все ж функціонують в рамках трьох головних: класичного, спортивного та фентезі.

Саме у цей час з'явилась новинка, що назавжди змінила моду - міні спідниця. То ж що це таке? По суті - невибагливий відріз тканини, навколо якого крутилася мода 1960-хрр. Вона стала символом підліткового бунту проти негласного правила "одягайся як мама" і дозволила молоді вперше проголосити свій стиль. Мері Куант, яка відкрила свій бутик "Bazaar" на Кінгс Роуд у Лондоні ще в 1955 р., належить першість якщо не у створенні, то в ринковому просуванні сучасної міні-спідниці [11]. Виріб дизайнерки, названий на честь улюбленої моделі автомобіля "Міні", став хітом десятиліття. У 1962 р. М. Квант, показала першу колекцію речей з довжиною міні. Новий стиль, названий "стилем Лондону", дуже швидко завоював прихильність молоді усього світу. Хоча ця модель була створена для дівчинки-підлітка, міні швидко стали носити майже всі жінки. За свою суттю вона стала тією безкласовою модою, яка найкраще відображала дух часу. Поява контрацептивів, довершуючи сексуальну революцію, вперше дала жінці змогу робити кар'єру і самій визначати межу своєї сексуальності. Панчохи з підв'язками, які раніше регулювали довжину спідниці, були відкинуті на користь кольорових колготок 3 принтами творів оптичного мистецтва та революційного поп-арту. 
Легендарні 1960-ті роки - це яскраве десятиліття в історії світової моди, вільне і експресивне, період урочистої ходи, так званої, молодіжної моди. Вони стали важливим вододілом в історії моди, адже саме тоді з'явилися перші молодіжні тренди в одязі. Протягом цього десятиліття ламалося безліч традицій та стереотипів. Довершували дизайнерські креатини соціальні рухи за права людини. Якщо раніше мода від-кутюр орієнтувалися на дорослих представників еліти, то з 60-х рр. колекціях лінії молодіжної моди. Таким чином, з'являється молодіжний стиль в одязі, який зароджується стихійно в середовищі самовпевненої молоді, яка хоче відрізнятися від усіх оточуючих не лише поведінкою, але й стилем. Індустрія моди використала ці прояви молодіжного екстремізму і розробила естетичні критерії нового, особливого стилю. У ньому є все, чого так прагнули молоді люди: і бунтівна сила "соціального визволення", і прихована "безсловесна опозиція", і шокуюча сміливість відкриттів. При створенні нових форм одягу використовуються близькі молодим людям стилі в мистецтві - поп-арт, оп-арт, неореалізм та ін.

Середина XX ст. була насичена різносторонніми подіями, що подарували світові інше бачення еротизму. Руді Гернрайх, американський модельєр німецького походження, ввів моду на відкритий бюст, що найкраще відобразилось у його колекції купальників "монокіні", а новинка 1965 р. бюстгарлер "no bra bra" - символізував остаточну перевагу простоти над складністю крою та свободу самовизначення над стереотипами [12]. Вже весною 1971 р. Р. Гернрайх представив світові нову колекцію одягу, навіяну подіями феміністичного руху, яку можна було різноманітно комбінувати. На подіумі стиль "мілітарі" демонстрували моделі, які тримали у руках іграшкові гвинтівки, що мало чіткий посил. Ця ідея - відображення війни проти нерівності, що досягнула критичної точки в кінці 1960-х рр., коли почались хвилі демонстрацій проти гендерних стереотипів.

Підсумовуючи, варто відзначити наступне, мода у всі часи $€$ важливою частиною життя суспільств та уособлює собою колективну пам'ять минулих подій. 3 1940-х рр. по 1970-ті рр. вона пережила сотні змін та модернізацій, створивши ґрунт для подальшого творення модних тенденцій. Для того, щоб розрядити атмосферу у післявоєнний час та внести у неї хоч якусь лепту шику Крістіан Діор, черпаючи натхнення у вікторіанській епосі, створює стиль "нью лук", який стає символом багатства у період дефріциту. Та незважаючи на його витонченість все ж традиційний образ "Леді" було зруйновано, на заміну якому прийшла жінка у діловому костюмі, який створювали низку високооплачуваних дизайнерів, зокрема Ів Сен - Лоран та Коко Шанель. Клер Маккарделл, підтримуючи тенденції, створила такий ж простий та елегантний одяг для жінок, проте дещо бюджетніший, щоб він став доступніший широким масам. Паралельно з тим у моді з'явились екстравагантні міні-спідниця та бікіні, які стали тою безкласовою модою, яка найкраще відображала дух часу. Відтепер не дизайнери диктували головні модні тенденції, а молодь, яка стала рушійною силою суспільних та модних змін 60-70-х рр. XX ст.

\section{Список використаних джерел:}

1. Rebecca Arnold, Fashion, Desire and Anxiety: Image and Morality in the 20th. (P. 24 ) New Brunswick, N. Y., Rutgers University Press 
2. The Way We Move. Slate Group.(2007). Retrieved from: https://slate.com/culture/2007/05/howpoiret-freed-us-from-the-corset.html

3. Coco Chanel: The Legend and the Life by Justine Picardie: review. Telegraph.(2010) - Retrieved from: https://www.telegraph.co.uk/culture/books/bookreviews/8034462/Coco-Chanel-TheLegend-and-the-Life-by-Justine-Picardie-review.html

4. Claire McCardell. Archives of Maryland.

Retrieved from: https://msa.maryland.gov/megafile/msa/speccol/sc3500/sc3520/013500/013581 /html/13581bio.html

5. Rebecca Arnold, Fashion, Desire and Anxiety: Image and Morality in the 20th. (P.31) New Brunswick, N. Y., Rutgers University Press,

6. Stainer R.L., Weiss J. (1951) Veblen Revised in the Light of Counter-Snobbery. Journal of Aesthetics and Art Criticism. (March. Vol. 9. No. 3), P. 263

7. Hawes E. (1939) Men Can Take It (P.2) New York: Random House

8. Rebecca Arnold, Fashion, Desire and Anxiety: Image and Morality in the 20th. (P.124) New Brunswick, N. Y., Rutgers University Press,

9. Obituary: Yves Saint Laurent. Telegraph.(2008). Retrieved from: https:/www.telegraph.co.uk/news/obituaries/culture-obituaries/2063264/Obituary-Yves-SaintLaurent.html

10. Rawsthorn A. (1996) Yves Saint Laurent: A Biography. (P. 112) London: Harper Collins

11. Історія моди. Ілюстрована енциклопедія з давнини до сьогодення (2014), с.41. Харків: Фактор,2014.

12. Rebecca Arnold, Fashion, Desire and Anxiety: Image and Morality in the 20th. (P.122) New Brunswick, N. Y., Rutgers University Press.

\section{ЄВРОПЕЙСЬКА МІГРАЦІЙНА КРИЗА ЯК ВИКЛИК СУЧАСНОСТІ}

Руда Вікторія Вікторівна кандидат історичних наук, доцент кафедри гуманітарних наук ДЗ «Луганський державний медичний університет»

УКPAÏHA

В останні часи в європейському світі спостерігається зростання етнічного сепаратизму, націоналізму, расизму та ксенофобії. Найбільше цей феномен проявляється у Німеччині, Австрії, Франції, Італії, Бельгії та Великобританії. Ці явища пов'язують із тривалою десятиліттями міграцією населення з країн Африки, Сходу та Азії, а також міграційної кризою, що виникла в Європі в 2015 р. та толерантною політикою та демократичним ставлення відносно мігрантів.

Ще на початку XXI ст. член Єврокомісії Фредерік Болкестейн під час свого виступу в Гаазі у 2001 р., зауважив, що іммігранти складають 8,8\% населення Нідерландів, а протягом найближчих 15 років їхня кількість зросте до $14 \%$ i вони становитимуть більшість населення двох найбільших конгломерацій Амстердама і Роттердама [1]. 
Європейська міграційна криза виникла через масові напливи мігрантів у країни ЄС. Серед причин міграційної кризи експерти часто називають збройні конфлікти, низький рівень життя в окремих державах, а також неефективну політику ЄС у цій сфрері [2]. За минулі 2017-2018 роки найбільшу кількість мігрантів прийняли Німеччина, Великобританія та Іспанія [3].

Негативними наслідками міграції прийнято вважати високий рівень безробіття, мігранти, як правило, не інтегруються у суспільство, не приймають його культуру та цінності, вони проживають відокремленно, створюючи щось на кшталт власних колоній у великих західноєвропейських містах, намагаючись зберегти свою національну та релігійну ідентичність, нездатність або небажання вивчити іноземну мову не дозволяє мігрантам розраховувати на робочі місця, тому вони стають додатковим соціальним навантаженням для країни. Загрозу безпеці місцевих жителів становлять і злочинні угруповання мігрантів. Серед мігрантів, особливо біженців, останнім часом набуває популярності принцип «переді мною всі боргують» [4]. Все це провокує міжетнічні та міжрелігійні конфллікти і підриває спокій в західноєвропейських країнах.

Європейська міграційна криза не лише спричинила сплеск міграційних потоків, але й привернула увагу на проблеми мігрантів в країнах $Є С$ та змусила всерйоз замислитися над цим питанням.

\section{Список використаних джерел:}

1. Борко, Ю. (2002). Быть ли единой «единой Европе» в XXI веке? Москва.

2. Луцишин, Г. (2015). Міграційна криза в ЄС: проблема безпеки зовнішніх кордонів та загострення міжетнічних Політичні науки, (1(2)), 41-45.

3. Дані Євростата Вилучено 3 https://ec.europa.eu/eurostat/statisticsexplained/index.php?title=Migration_and_migrant_population_statistics\#Migrant_population:_22 .3_million_non-EU_citizens_living_in_the_EU_on_1_January_2018

4. Чуєнко, В.І. (2017) «Європейська криза біженства»: причини формування Науковий вісник Ужгородського національного університету. Серія: Право, (43(2)), 211-215. 


\title{
ІСТОРІЯ ФОРМУВАННЯ УКРАЇНСЬКОЇ КУХНІ
}

\author{
Орлова Ганна \\ студентка технологічного відділення \\ Криворізький державний комерційно-економічний технікум \\ НАУКОВИЙ КЕРІВНИК: \\ Лисенко Віталій Сергійович \\ методист технікуму \\ Криворізький державний комерційно-економічний технікум \\ УКРАÏHA
}

Українська кухня складалася протягом багатьох століть, що обумовило ії̈ різноманітність, страви української кухні, відрізняються високими смаковими та поживними якостями, різними комбінованими методами обробки продуктів і складною рецептурою.

Отже, по-перше, українська національна кухня була створена на базі вже сформованих у кожній з регіональних частин України елементів кулінарної культури. Відмінності між блюдами Чернігівщини і Галичини, Полтавщини і Волині, Буковини і Харківщини, Поділля і Закарпаття збереглися до наших днів.

По-друге, внаслідок величезності території, що розкинулася від Карпат до Приазов'я і від Прип'яті до Чорного моря, ці елементи були дуже різнорідні. Але відмінності природних умов і історичного розвитку окремих частин України, сусідства безлічі народів (росіяни, білоруси, татари, ногайці, угорці, німці, молдавани, турки, греки), не завадили українській кухні сформуватися на рідкість цільною, навіть трохи однобічною як по відбору характерної національної харчової сировини, так і за принципами її кулінарної обробки [1].

По-третє, у національну українську кухню не ввійшли традиції давньоруської кухні, зв'язок з якою був втрачений після монголо-татарської навали. Це відрізняє українську кухню від російської і білоруської, де давні традиції, хоча і видозмінювалися, але, проте, зберігалися протягом багатьох століть.

Разом з тим українська кухня сприйняла деякі технологічні прийоми не тільки німецької й угорської кухні, але і татарської і турецький, по-своєму частково видозмінивши їх. Так, обсмажування продуктів у перегрітій олії, що властиве для тюркських кухонь, було перетворено в українське «смаження» (тобто пасерування овочів, що йдуть у борщі чи в другі страви), що, наприклад, абсолютно не властиво українській кухні. Пельмеподібне блюдо турецької кухні дюш-вара перетворилося спочатку у варанікі, а потім вже в українські вареники з характерними національними наповнювачами - вишнями, сиром, цибулею, шкварками. 3 німецької кухні було сприйняте дроблення продуктів, що знайшло вираження в різних українських «січениках» - котлетоподібних стравах з фраршів (січених, подрібнених м'яса, яєць, моркви, капусти, грибів і т. д.) [2].

На кожну народну кухню перш за все впливає конструкція місця, де готують їжу, тобто домашнього вогнища. В Україні таким місцем була "вариста піч", кострище закритого типу. Тому, українська кухня в основному використовує прийоми варіння, тушкування і печива. Навіть козаки, підстреливши дичину, 
намагалися зварити з неї юшку (бульйон), а не підсмажити на рожні, що більш властиво німцям, наприклад.

\title{
Список використаних джерел:
}

1. Шалимов, С. А. \& Шадура, Н. П. (1989) Современная украинская кухня. Киев: Техника.

2. Украинская кухня (2000). Днепропетровск: Сталкер.

\section{ОБСІВАННЯ ТРАДИЦІЙНОЇ ПОКУТСЬКОЇ САДИБИ НА ЩЕДРИЙ ВЕЧІР}

\begin{abstract}
Досінчук Сергій Юрійович
магістрант кафедри етнології та археології

Прикарпатський національний університет ім. В. Стефраника

Соловей Уляна Борисівна

магістрант кафредри етнології та археології

Прикарпатський національний університет ім. В. Стефаника

УКРАÏHA
\end{abstract}

Народна архітектура Покуття, будучи матеріальною культурою, найкраще відображає духовне життя населення краю. На Покутті переважали двокамерні житла. Двокамерне житло на Покутті зазнавало пройшло шлях еволюції. Першими ускладненнями такого простого типу планування стану виділення в сінях окремого приміщення для зберігання збіжжя, яке отримало назву комора. Зміна системи опалення також змінювала і вигляд оселі. Таким чином утворився новий тип планування оселі : хата + сіни + комора [1].

Цей тип житла зустрічався на Покутті і у XX ст. Саме з нього розвинулись i досконаліші трикамерні типи планування житла типу хата + сіни + хата двох варіантів: з різними розмірами кімнат (часто одна велика і тепла, а інша мала і холодна) або однаковими за розмірами житловими приміщеннями, які тут називали "хатою на дві половини». Велику кімнату називали «хата», тоді як менше приміщення іменували «хатчина». Варто зауважити, що «хатою» називали і весь житловий простір. Побутував також тип хата+сіни+комора, який був притаманний для усіх сіл Покутського краю. Окрім Покуття, такий тип житла був притаманний Карпатському регіону та Бойківщині [2].

Рідні стіни житла вважались своєрідним захистом селян від «чужого» світу, тому на свята відбувався цілий цикл обрядодій, спрямований на оберіг оселі від «нечистої» сили на цілий рік, де кожен предмет інтер'єру відігравав важливу роль.

Сакрального значення в інтер'єрі покутської хати мали вікна, які були зв'язком зовнішнього (чужого) та внутрішнього (рідного) світів, тому перед святом над ними поновлювались вирізьблені хрести, які служили символічними знаками для охорони оселі.

Найважливу роль відігравав стіл: уособлював ідею єдності та злагоди сім'ї, iї годувальника. Тому його завжди намагались застеляти чистими скатертинами, щоб таким чином висловити повагу до нього. Зберігся звичай і тримати на столі хліб і сіль, на святвечір сюди ж господиня накладала сіно, що означало її гостинність [3]. 
Цікавий звичай зберігся у селі Колінці Тлумацького району: якщо на Старий Новий рік першим до хати заходив кінь, то це помножувало здоров'я і добробут для всієї родини. Коня «прикрашають» різними кольоровими стрічками та супроводжуюсь по цілому селу всю ніч засівальники. Варто зауважити, що у XXI ст. не всі господарі дозволяють заводити коня в оселю, обмежуючи це тільки територією садиби.

За тиждень після коляди, напередодні Нового Року - Щедрий Вечір. Це залишок стародавнього, імовірно, дохристиянського звичаю. За християнським календарем - це день преподобної Меланії. В народній традиції обидва свята об'єднались, і тепер маємо Щедрий Вечір або свято Меланки. Наддніпрянська Україна і Гуцульщина святкують Щедрий Вечір як значне свято різдвяного циклу з добре розвиненою обрядовістю. Галицьке Поділля не святкує, бо Щедрий Вечір у галичан - напередодні Водохрищів, тоді як на Наддніпрянщині це - «Голодна кутя», Богоявленне надвечір'я. В Україні на Щедрий вечір батько ховаєься від дітей за пирогами - символом щедрости, багатства![4].

На Старий Новий рік - Василя, окрім служби в церкві, традиційно зранку ходили посівати посівальники-хлопчики, обсіваючи зерном оселі родичів, сусідів, знайомих. Посівальниками мають бути хлопці, оскільки існує повір'я, що першим на Новий рік мав зайти в хату чоловік, щоб все було добре і в родині, і в господаря. Посівали злаками, в основному - житом, пшеницею. Першому засівальнику, як правило, приділялася особлива увага, тому зранку хлопці намагалися встати якомога раніше, щоб бути першим. Всі засівальники отримують грошову винагороду, яку залишають собі або частину віддають на церкву [4].

Як засвідчує етнографічна література та польові спостереження, досі дотримуються правила не заходити до сусідської хати не лише на свято Введення, але й на Святий вечір, Різдво, Новий рік (Василя), Йордан. Ось що про це згадують респонденти: «Колись давно я казала до своїх дітей: «На Різдво, аби ніхто ні до кого не пішов!» (с. Стриганці на Тлумаччині). Проте, у Великому Ключеві (Коломийщина) вірять, що «дуже добре, якщо на Святвечір якась чужа людина прийде і сяде до вечері. Кажуть, що в хаті буде все гаразд»[5].

Отже, можемо зробити висновок, що з на Покутті здавна існував обряд посівання садиби, який мав би прикликати добро та забезпечити врожайний наступний рік. Не дивлячись на трансформаційні процеси в духовній культурі українців Карпатського регіону, можемо зазначити що саме в цій місцевості (покутський етнорайон) до теперішніх днів зберігся обряд посівання на Щедрий вечір (Старий Новий рік).

\section{Список використаних джерел:}

1. Самойлович, В.П. (1972) Українське народне житло. Киї̈в: Наук.думка.

2. Сілецький, Р.Б. (1994) Сільське поселення та садиба в Українських Карпатах XIX-XX ст. Київ: Наук. думка.

3. Кожолянко, Г.К. (2009) Сакральні місця в традиційному житлі українців Буковини. Карпати: людина, етнос, цивілізація, (1) 151-157.

4. Воропай, О. І. (1991) Звичаї нашого народу: етнографічний нарис. Т1. - Київ:Оберіг.

5. Серебрякова, О. (2017) Прикмети, заборони та настанови населення Покуття (на прикладі зимового циклу свят). Народознавчі зошити, (5) 1126-1133. 


\title{
SECTION XIV. POLITICS
}

\section{ПОЛІТИЧНИЙ АНАЛІЗ КОРЕЙСЬКОЇ ВІЙНИ 1950-1953 РР. ТА ІІІ ВПЛИВ НА РОЗВИТОК СУЧАСНИХ ПОДІЙ НА КОРЕЙСЬКОМУ ПІВОСТРОВІ}

\author{
Петрова Катерина Олегівна \\ студентка IV курсу історичного факультету \\ Запорізький національний університет
}

УКPÄ̈HA

Постановка проблеми. Запуск балістичних ракет з боку Північної Кореї у напрямку Японського моря, пряма погроза Республіці Корея та США від північнокорейського лідера, який заявив про готовність КНДР продемонструвати свою військову міць, у тому числі ядерну, у випадку продовження американо-південнокорейського військового вчення, - все це реалії сучасних напружених відносин між двома корейськими лідерами. Нещодавні події на Корейському півострові продемонстрували всьому світу, що військовий конфлікт, який розпочався у 1950 році між КНДР та Республікою Корея $€$ незакінченим. Тому аналіз цієї проблеми та пошук ефективних шляхів ії вирішення - $€$ ключовим завданням для науковців з різних кутків планети, для лідерів провідних країн світу та для міжнародних організацій.

Аналіз останніх досліджень і публікацій. Дослідженням та аналізом військових подій на Корейському півострові у період з 1950 по 1953 рр. займалися такі провідні вчені: І. Д. Коміренко, Е. Тихонов, К. Данильченко, Р. Маккой, Б.В. Соколов та інші. Вони виокремили причини військової конфронтації між лідерами КНДР та Республіки Корея, дослідили динаміку конфрлікту та виокремили економічні наслідки цієї війни, які в майбутньому вплинули на розвиток цих країн.

Нажаль, досить мало робіт присвячено саме дослідженню політичних наслідків Корейської війни, які вплинули на формування сучасних відносин між корейськими лідерами. Тому вивчення цієї теми та аналіз сучасних подій на Корейському півострові залишається актуальним завданням на сьогоднішній день.

Мета статті. Метою даної роботи є аналіз впливу військових подій на Корейському півострові у 1950-1953 рр. на розвиток сучасних відносин між лідерами КНДР та Республіки Корея.

Основні результати дослідження. Конфолікт, що виник між Республікою Корея та США з одного боку та КНДР, СРСР та КНР з іншого боку у 1950 році мав свої історичні передумови. Однією з головних причин, що призвела до виникнення Корейської війни, є розкол єдиної Кореї на дві держави з різним соціально-політичним устроєм та зовнішнє втручання з боку США та СРСР у події, що розгорталися на Корейському півострові. Адже тоді, у 1945 році, єдина Корея була умовно поділена на зони впливу СРСР та США по 38-й 
паралелі, у результаті чого були сформовані два різних світогляди на формування єдиної політичної системи та подальший розвиток країни: прорадянський та проамериканський [4]. Як президент Південної Кореї Лі Син Ман, так і 1-й генеральний секретар Корейської Трудової Партії Кім Ір Сен не приховували своїх намірів: дві корейські держави мали об'єднатися. Але потреба кожної зі сторін полягала в об'єднанні Корейського півострова під егідою своєї влади, не допускаючи встановлення впливу на територію усієї країни з боку свого супротивника. Обидва лідери, що мали різні погляди на майбутнє управління Кореї, вбачали досягнення своєї мети лише за допомогою військової сили. Окрім цього, Республіка Корея та КНДР переслідували власні мотиви у випадку розгортання військових дій на Корейському півострові. Встановивши свою владу на півострові, Кім Ір Сен зміг би ослабити позиції США на цій території та показати військову міць КНДР сусіднім країнам, у майбутньому прагнучі поширити свій вплив на території цих країн. Лі Син Ман у свою чергу прагнув закріпити свої позиції на Корейському півострові, продемонструвавши свої військові сили і необхідність рахуватися 3 його точкою зору. Для цього, Кім Ір Сен запросив допомогу у вигляді фінансування війни та надання військової зброї у СРСР з одного боку, а Лі Син Ман - у США з іншого боку.

Необхідно наголосити на тому що СРСР, КНР та США підбурюючи дві країни до війни переслідували власні цілі, яких вони хотіли би досягти 3 початком Корейської війни. Так, наприклад, для СРСР та КНР було пріоритетним завданням послабити позиції США на території Корейського півострова, а США прагнули не допустити розповсюдження влади Кім Ір Сена на територію усього Корейського півострова, що перебував під протекторатом СРСР [2]. Разом з цим обидві сторони мали власні побоювання щодо розгортання цього конфлікту. СРСР з одного боку боялися прямого зіткнення із США та розгортання війни з використанням ядерної зброї, а США, у свою чергу, були проти перетворення локальної війни на глобальну. Саме тому, аж до 1950 року обидві країни відмовляли корейським лідерам у наданні фінансової підтримки у разі розгортання війни.

Тим не менш, конфлікт між Республікою Корея та КНДР вже зародився i відступати від своїх намірів обидва лідера не планували, тому вирішити конфрлікт мирним шляхом вже було неможливо.

\section{Динаміка конфлікту:}

- Періодизація бойових дій в Корейській війні включає чотири етапи:

- перший (25 червня - 14 вересень 1950 г.), що складається з переходу КНА через 38-у паралель, активний наступ на Республіку Корея до р. Нактонган 3 блокуванням військ противника на плацдармі в районі м Пусан;

- другий (15 вересня - 24 жовтень 1950 г.), що містить контрнаступ багатонаціональних сил ООН і їх вихід безпосередньо в південні райони КНДР;

- третій (25 жовтня 1950 р - 9 липня 1951 г.), що характеризується вступом у війну китайських народних добровольців, що призвело до відступу військ ООН з Північної Кореї і стабілізації лінії бойових дій на півострові в районах, прилеглих до 38-ї паралелі;

- четвертий (10 липня 1951 р - 27 липень 1953 г.), що включає в себе як бойові дії, так і переговори про перемир'я [1]. 
76 Problems and prospects of implementation of innovative research results $\bullet$ Volume 4

\begin{tabular}{|l|l|}
$\substack{\text { Позиція: встановити свій вплив на } \\
\text { Корейському півострові військовим } \\
\text { шляхом }}$ & $\begin{array}{c}\text { Позиція: відповісти на виклик } \\
\text { КНДР та об'єднати Корею під } \\
\text { егідою Лі Син Мана }\end{array}$ \\
\hline
\end{tabular}

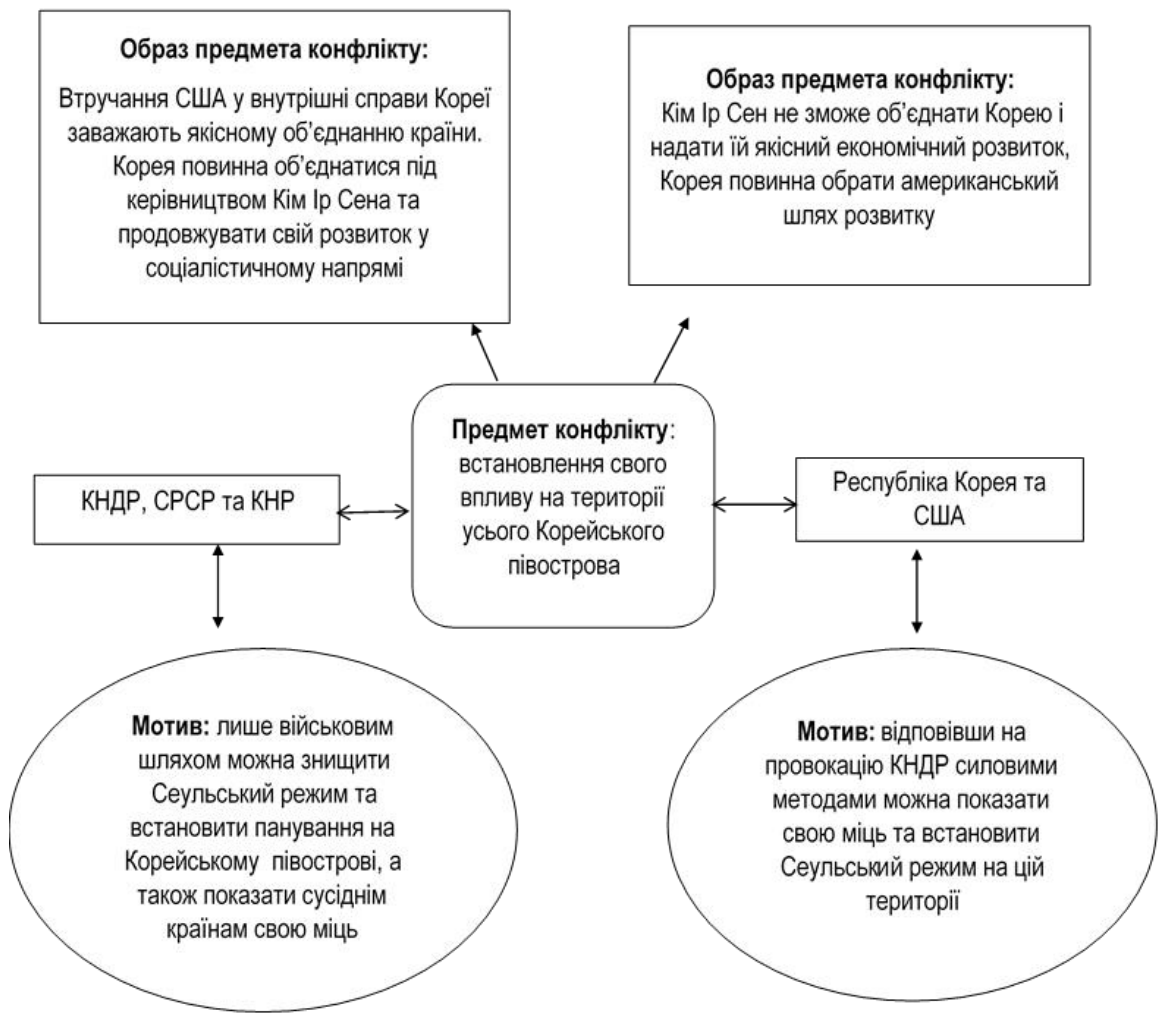

Рис. 1. Структура конфлікту

Розв'язка конфлікту: Після того, як у 1952 році президентом США став Дуайт Ейзенхауер, політичний курс США був направлений на необхідність швидкого вирішення цього конфлікту і вироблення стратегії, яка могла б зупинити військові дії на Корейському півострові [2]. Окрім цього, поворотним моментом у вирішенні цього конфлікту стала смерть Сталіна, після якої Президія ЦК КПРС проголосувала за припинення війни.

КНДР та Республіка Корея, які втратили підтримку з боку СССР та США були вимушені сісти за стіл переговорів і домовитися про обмін полоненими та майбутнє співробітництво. Таким чином, 27 липня 1953 року був ухвалений договір про перемир'я між двома країнами. Але навіть після укладення цієї угоди конфолікт не припинився [2]. Диверсії, обстріли, теракти, морські битви і 
висадки десантів продовжилися. Тому формально, Корейська війна триває досі.

Для Республіки Кореї та КНДР наслідки цього конфрлікту є надзвичайно негативними. На Корейському півострові було зруйновано понад $80 \%$ промислової та транспортної інфраструктури обох держав, три чверті урядових установ, близько половини всього житлового фонду. Обидві сторони конфрлікту винні у вбивствах мирного населення (понад 4 млн осіб загинули за три роки ведення кровавої війни) [3]. Окрім того, надмірне захоплення конфрліктом призвело до економічного занепаду обох країн, а після завершення військових дій відновлення стосунків між Республікою Корея та КНДР стало майже неможливим. На сьогоднішній день, обидві сторони поглинають плоди цього конфлікту, не бажаючи сісти за переговорний стіл та знайти компроміс. Балістичні ракети, які були запущені КНДР нещодавно та погроза ядерною зброєю сусідній країні, яка у минулому була єдиним цілим, говорить про несумісність поглядів двох корейських лідерів щодо шляху розвитку взаємних відносин. Різний соціально-політичний устрій, який був закладений у КНДР з боку СРСР та у Республіці Корея з боку США, породив непорозуміння між двома корейськими лідерами та жагу до об'єднання країни лише під егідою одного лідера. Нажаль, потреба в об'єднанні держави під егідою одного корейського лідера та побоювання щодо розповсюдження влади іншого політичного діяча, набирає швидкі оберти та призводить до серйозних сутичок між КНДР та Республіка Корея у сучасному світі.

\section{Список використаних джерел:}

1. Коміренко, І.Д. (2004). Корейська війна 1950-53. Київ: Знання України.

2. Тіхонов, Е. (2019). Корейська війна. Вилучено з: https://militaryarms.ru/voennyekonflikty/korejskaya-vojna/

3. Данильченко, К. (2019). Корейська війна: 7 уроків для Дональда Трампа. WASmedia. Вилучено 3: https://was.media/uk/2017-11-27-korejska-vijna-7-urokiv-dlja-donalda-trampa/

4. Маккой, Р. (2018). Корейська війна. Погляд з «іншої» сторони. Asiatimes. Вилучено з: https://inosmi.ru/politic/20180801/242875657.html 
78 • Problems and prospects of implementation of innovative research results $\bullet$ Volume 4

\section{SECTION XV. GEOGRAPHY}

\section{АНАЛІЗ ПРОЦЕСІВ РУСЛОФОРМУВАННЯ НА РІЧЦІ ВОРСКЛА}

\section{Тепайкіна Дарія Віталіївна}

учениця 10-М класу

Полтавського обласного наукового ліцею-інтернату імені А. С. Макаренка

НАУКОВИЙ КЕРІВНИК:

Глухота Віталій Олександрович

вчитель II категорії

Полтавського обласного наукового ліцею-інтернату імені А. С. Макаренка

УКРАÏHA

Як відомо, з часом русла рік змінюють своє планове і висотне положення. 3а 30-50 років річка може зміститись на відстань, що дорівнює ширині русла, або може з'явитися нова протока.

Вивчення закономірностей протікання руслових деформацій річок дає можливість передбачати їх розвиток, прогнозувати негативні впливи на екологію водойми, умови водокористування та господарські об'єкти довкола неї.

Загальним проблемам деформації русла річок приділено досить багато уваги українськими та зарубіжними вченими: О. Г Ободовським [1], Р. С. Чалова [2] та ін. Деформаційні процеси полтавських водойм висвітлені у працях В. Г Смирнової, на прикладі річки Псел [3].

Щодо Ворскли, як однієї з найбільших водойм регіону відповідних наукових досліджень не проводилося, що і становить актуальність дослідження.

Мета роботи - дослідити деформаційні процеси русла річки Ворскли в межах Полтавської області.

В залежності від розвитку руслових процесів відносно напрямку сили тяжіння виділяють два види руслових деформацій:

- вертикальні, що викликають трансформацію поздовжнього профрілю річки і зміну відміток дна русла;

- горизонтальні, пов'язані з переміщенням русла в плані та розмиванні берегів.

Щодо вертикальних руслових деформацій Ворскли, згідно з даними О. Г. Ободовського спостерігається чітка тенденція до зростання рівнів води для різних витрат. Це свідчить про накопичення в руслі річкових насосів і перевалювання в них акумулятивних процесів [1].

Русло річки Ворскла знаходиться в умовах вільного розвитку руслових деформацій. Зміна середніх показників коливається від -0,01 cм/рік поблизу Чернетчини до +0,68 см/рік біля Кобеляк [1].

Горизонтальні руслові деформації Ворскли мають незначні швидкості планових переформувань і спостергіаються на нижніх ділянка русла річки, для 
якої характерна руслова та заплавна багаторукавність на фоні слабвираженого меандрування.

Максимальна інтенсивність горизонтальних деформацій водойми складає від 0,42 м/рік біля Чернетчини до 1,51 м/рік поблизу Кобеляк. Середня інтенсивність горизонтальних деформацій скаладає від 0,20 м/рік в районі Чернетчини, до 1,12 м/рік біля Кобеляк [1].

Особливість протікання горизонтальних руслових деформацій на річці Ворскла ми проаналізували на основі співставлення карти 1868 року видавництва Військово-топографрічного відділу Головного штабу Російської імперії в масштабі в 1 см 4,2 км. та космічних знімків Google Maps.

В районі Котельви чітко можна простежити наявність двох русел Ворскли східне та західне, згідно карти 1868 року. Якщо ж поглянути на космічний знімок то помітно, що водойма змінила русло в східному напрямку ближче до Котельви. Фактично західне русло перестало фрункціонувати. Причина зміни русла в даному випадку пов'язана з людською діяльність, а саме вирубка лісу.
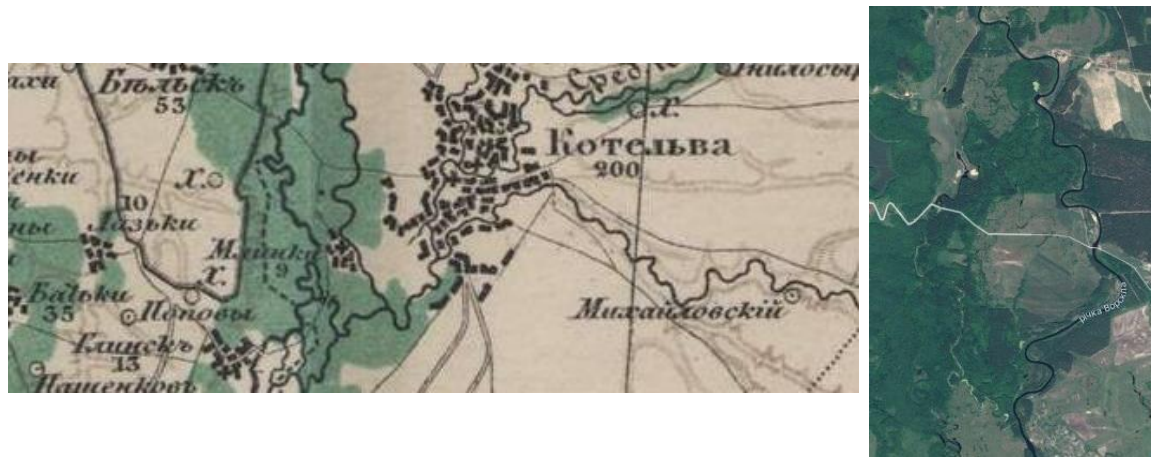

\section{Рис.1. Співставлення русла Ворски в 1868 року і сучасного положення}

Поблизу села Михайлівка русло річки робить «різкі повороти», згідно з космічними знімками, але 150 років тому для цієї ділянки було характерне нявність двох замкнутих петель. В даному випадку відповіні зміни теж повязані з людською діяльністю.

В межах міста Полтави русло Ворскли теж подвійне, згідно карти 1868 року, але навідміну від подібної особливості поблизу Котельви, слідів старого русла залишилося дуже мало, можливо це пов'язано з більшою зміною ландшафтів довкола нього, зокрема при прокладанні залізниці.

В нижній течії річки Ворскли, в районі міста Кобеляки, русло водойми мало змінило свій напрямок, але південніше міста можна побачити стариці, які в минулому були частиною русла річки, на даний час згідно знімків є окремими водоймами.

Цікавим $є$ аналіз зміни гирла Ворскли. Як відомо в 1965 році відбулося наповнення Кам'янського водосховища, яке фрактично знищило природне гирло водойми. На даний час воно являє собою розгалужену систему рукавів, проток, стариць, які в минулому були одним руслом річки. Згідно з карти 1868 року при впадінні гирло Ворскли утворювало декілька петель, але їх досить складно помітити на космічних знімках, тому співставити відповідні карти $€$ досить проблемно [3]. 
80 - Problems and prospects of implementation of innovative research results $\bullet$ Volume 4
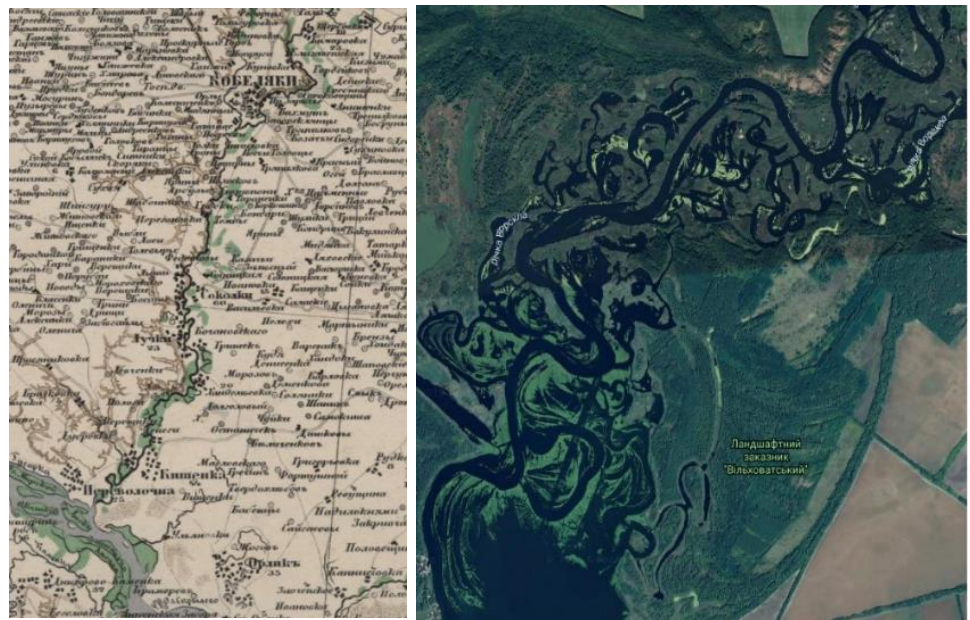

Рис. 2. Співсталвлення гирла Ворскли 1868 року і сучасний стан

На основі класифрікацій Р. С. Чалова [2], де науковець виділила сім основних типів річкових русел: вільно меандруючі, врізані меандри, врізані прямолінійні, адаптовані згини, відносно прямолінійні, розгалужені на рукава, каналізовані. Ми провели аналіз русла річки Ворскла в межах Полтавської області з допомогою космічних знімків Google Maps та інших картографічних творів.

На території Котелевського району русло Ворскли вільно меандрує і має сегментну та петлеподібну форму

Поблизу села Міські Млини русло розгалужується на рукава, що $є$ наслідком будівництва Опішнянської ГЕС, також заплава водойми має велику кількість стариць, які утворилися внаслідок зміни водного режиму і відповідно русла через будівництво даної ГЕС.

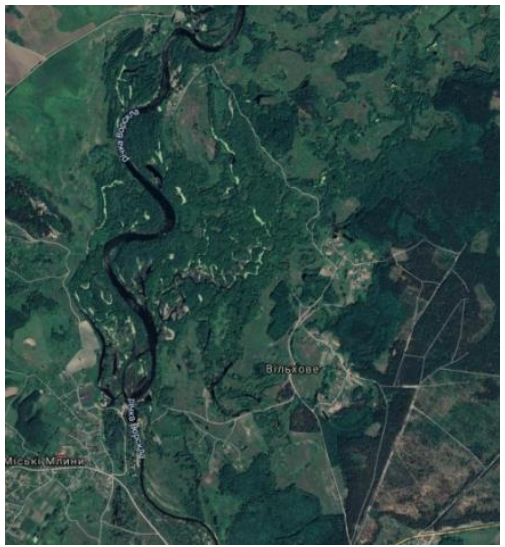

Рис. 3 Сегментне та петлепотібне русло Ворскли 
Далі русло Ворскли знову вільно меандрує утворюючи сегменти та петлі. Поблизу села Писарівщина русло має синусоїдальну форму, також в заплаві знаходиться велика кількість стариць.

Нижче течії русло меандрує петлеподібно і має фрорму прямого кута. Додаток 4 Біля села Михайлівка воно має велику кількість петель і наче повертається у зворотньому напрямку. В даному районі частково порушується закон сили Коріоліса коли водний потік підмиває лівий берег, а не правий.

Докола сіл Ворони, Гавронці русло знову вільно меандрує утворюючи сегменти та петлі різної величини. Поблизу села Сем'янівка утворює петлю у вигляді прямого кута.

Вакуленська гребля, яка знаходиться нижче за течією, теж змінила русло Ворскли, утворивши старицю. В межах Полтави Ворскла знову вільно меандрує утворюючи сегменти та невеликі петлі. При впадінні в неї річки Коломак значно розширююється і розгалужується на рукава і утворює так зване прорване русло.

Нижче за течією, поблизу села Буланово, утворює велику кількість петель різної форми та довжини. На окремих ділянках має прямолінійну форму та ледь помітні сегменти, які можна спостерігати аж до Старих Санжар. Особливо слід відзначити наявність островів на даній ділянці, що означає наявність прорваної вільної меандри.

Поблизу Кобеляк русло має синусоїдальну форму. В межах міста прямолінійну форму, нижче за течією, за мостовим переходом, утворює петлі різної форми. Далі до гирла, русло Ворскли можна спостерігати велику кількість стариць, і чим ближче до гирла тим їх число буде збільшуватися

Гирло Ворскли утворює дельту, яка виникла в результаті наповнення Кам'янського водосховища. Русло в цій ділянці дуже звивисте, утворює петлі різного розміру, а також прорвану вільну меандру.

Отже, за майже 150-річний період русло Ворскли достатньо помітно змінило своє положення. Доказом цього є наявність великої кількості стариць в заплаві водойми. Велика кількість руслових петель різного розміру $є$ доказом подальших змін русла Ворскли.

\section{Список використаних джерел:}

1. Ободовський, О. Г. (1998). Руслові процеси. Київ: ВПЦ «Київський університет».

2. Чалов, Р. С. (1996) Историческое и палеорусловедение: Историческое и палеорусловедение: предмет, методы иследование и роль в изучении рельефа. Геормфология (4), 17-22.

3. Смирнова, В. Г. (2011) Антропогенні зміни гідрографічної мережі Полтавської області. Гідрологія, гідрохімія, гідроекологія. (22), 60-67.

4. Тепайкіна Д. В. (2019). Аналіз процесів руслосрормування на річці Ворскла. Наука та інновації - 2019: теорія, методологія та практика: матеріали міжнародної наукової конфреренції (Т. 5, с. 127-131), 6 грудня, 2019 рік. Запоріжжя, Україна: МЦНД. [репринт]. 


\title{
SECTION XVI. ARCHITECTURE AND ARTS
}

\section{ATRIUM IN THE STRUCTURE OF HEALHCARE INSTITUTION}

\author{
Olena Konoplyova \\ PhD in Architecture, Associate Professor of Department «Design of Environment» \\ Kharkiv State Academy of Design and Fine Arts
}

Alisa Bondarenko student Kharkiv State Academy of Design and Fine Arts UKRAINE

Atrium space is a large recreational and communicative space of a public building, developed to its full height and covered with a light-transmitting roof. Features of atrium spaces are revealed in the compositional organization of a number of spaces of the past times. These are atriums, theaters, temples, prognosis projects of Claude Nicolas Ledoux, halls of industrial exhibitions of the late eighteenth century, greenhouses, winter gardens, glazed yards and arcades in the interiors of buildings. These historical prototypes, which had different combinations of core features, became the basis for the formation of the first atrium spaces in the middle of XIX century.

The atrium appeared in a climate where there was no need for home heating, and open unclosed space flooded with natural light was suitable for everyday life without additional insulation measures regardless of the season. The possibility of building large spaces with comfortable temperature and creating the effect of being outdoors made the atriums relevant for less appropriate climatic zones. Today the Atrium is an architecture not only of the Mediterranean, but also of Europe, Scandinavia and North America. With the development of technologies, glazing systems have emerged and allowed to build transparent constructions over such yards, so they have gained new functional qualities [1].

Latest technologies in modern construction enable architects and designers to work with grand open spaces of atriums filled with sunlight and with comfortable microclimate inside. Usually different elements of landscape architecture are used such as waterfalls, huge aquariums, fountains, etc. Such space gives a person a sense of integrity with nature, air, light, promotes relaxation of the nervous system. The vast space of the atrium, a translucent construction, can be organized in many ways. For example, in such an amazing atrium a seating area, a very welcoming lounge and a winter garden can be perfectly placed, and all of these things can be combined at once. But no doubt, most large translucent protective constructions take the opportunity to have large and cozy landscaped gardens in their interiors. After all, each evergreen flowering garden gives a chance for daily real communication with living nature: both in hot summer months and long rainy days of autumn, and in snowy and cold months of winter [2]. 
The best way to evaluate the impact of atrium, as an element of architecture, is becoming possible if using it in medical institutions - the places where people come because of poor state of health. None wants to leave everyday life and to get stuck within four walls, that is why the task of specialists is to create conditions under which space around will not put pressure on a person. The environment around is healing, and this is repeatedly confirmed by various studies of foreign experts. For example, there is a study about the impact of visual and physical contact of patients with plants what causes rapid recovery. Therefore, simple concrete boxes in the asphalt area will not help patients feel better. The presence of loving people close to the patient reduces stress - this should not be forgotten while designing medical centers.

Often, the atmosphere and conditions in healthcare institutions have negative impact on patients, placing strain on them even greater. Such trend suggests rethinking the design experience and organizing space in medical institutions. It is necessary to approach the question not only taking into account productivity, functionality, capacity and hygiene requirements, which are the key issues for modern medical institutions, but also the atmosphere of the health institution, which consists of the architecture effect of the building itself, planned purposes and functionality of the premises, all interior spaces for increasing the efficiency of patients' staying there.

Nowadays, all around the world new architecture solutions are used for designing modern healthcare institutions, and these solutions take into account new level of technical capabilities and aesthetic views of society.

Modern architecture of medical establishments with large glazed areas or atriums, which let in a lot of light - are the sources of life, which demonstrate even higher level of technologies by means of architecture planning and spatial solutions, moreover if it is equipped with the latest medical achievements of equipment and knowledge of specialists - all these factors should give a visitor a feeling of security and confidence in the effectiveness of the assistance provided, and create a positive sense of composure and comfort.

The ability of a patient to navigate easily around the hospital - it is awareness that a person can successfully move around the clinic doing that only with the help of signs and relative marks - reduces stress level and increases confidence [2].

Interior designs of medical establishments should be done at a high aesthetic level. It is necessary to use natural materials, daylight; realistic imitation of home atmosphere is also welcomed. Views from windows, lots of fresh flowers, objects of art - paintings, photographs, sculpture, etc., used in design of rooms, help to adjust a patient to positive thoughts, distracting from the reason of staying in hospital - all these aspects have positive effect on a patient's condition, contributing to the fast recovery.

Reducing the negative noise background is an important task for architects and designers working with construction and renovation of healthcare facilities. The sound background of the modern urban environment, filled with the constant noise of man-made nature, causes uncomfortable feelings and can be a source of stress. The opportunity to have a special relaxing sound background is essential for patients who are vulnerable to external irritants and who need special treatment. 
Moreover, such patients should not hear the sounds of opening and closing doors, the noise of equipment and the rumble of voices [4].

A color solution in a medical establishment has to bring about several functions at once. First of all, it helps in orientation within the hospital, dividing and marking the functional areas of the hospital inner space. It is also stated that color can affect person's mental state and mood and is able to alleviate one's painful feelings and physical discomfort. Some healthcare professionals suggest placing patients with high-temperature into the rooms in blue-violet coloring, while others whose illness does not cause fever should be placing into the rooms where walls have warm shades.

Expansion of premises of a healthcare establishment may be done due to advent of previously extrinsic spaces for hospitals such as reading zones, greenhouses, small tea or coffee rooms, areas for comfortable communication with visitors - relatives, friends; chapels, prayer rooms, etc [3].

Creation of an architectural space for medical activity is a complex process, and designers must take into account that it is primarily a social space of medicine.

In Europe, a new scientific direction called "architecture of health" is under development, which envisages the steps of improving the quality of treatment and satisfaction of a patient, preserving one's dignity, realized with the help of a new architecture with therapeutic functions.

Let's see how the things are going with the architecture and the environment at the Erasmus University Medical Center in Rotterdam. The complex includes various institutions. For example, there is the McDonald's Center. The main wings are built in a modernist style.

Hospitals of the past have been associated with confined environment with little daylight and narrow corridors. The experience of foreign architects and designers of public buildings shows that hospitals should be psychologically comfortable.

Modern architecture of healthcare institutions with large glass areas or atriums lets in a lot of light - a source of life, which demonstrates a high level of technology by architectural and space-spatial solutions, moreover hospitals are equipped with the latest medical achievements - equipment and knowledge of specialists; so a visitor of such hospital should feel secure and confident in the efficiency of the care provided, and a positive sense of peace and comfort should also be evoked.

\section{References:}

1. Sakson, R. (1987). Atriumnye zdanyia [Atrium Buildings]. Stroyizdat, pp. 135 [in Russian].

2. Borodyna, A. Y. (2010). Arkhytektura i dyzain medytsynskykh uchrezhdenyi [Architecture and design of healthcare institutions]. Meditsyna Peterburha № 22 [in Russian].

3. Runhe, V. F. (2005). Erhonomika $v$ dizayne sredy: uchebnoe posobie dlya studentov $i$ prepodavateley arkhitektury, dizainerov, i khudozhestvennykh vuzov [Ergonomics in environment design: study guide for students and teachers of architecture, designers, and art universities]. Arkhytektura-S [Architecture-S], pp. 328 [in Russian].

4. Nazarova, M. P. (2013). Arkhitekturnoe prostranstvo kak sotsiokulturnyi fenomen. [Architectural space as socio-cultural fenomena]. Volhohrad, pp. 49 [in Russian]. 


\section{AUGMENTED REALITY: FUNCTIONS, DIRECTIONS OF APPLICATION}

RESEARCH GROUP:

Svitlana Kryvuts

PhD (Design), Associate Professor

Kharkiv State Academy of Design and Arts

Olena Gonchar

$\mathrm{PhD}$ (Design) Associate Professor

Kharkiv State Academy of Design and Arts

Olga Popova

Younger science specialist Kharkiv State Academy of Design and Arts

UKRAINE

The diversity of information technology and software enhancements grows rapidly every year. The emergence of new materials and technologies, as well as the emergence of new ideas, new situations, new human relationships, leads to a change in the associative field, which contributes to the emergence of new types and genres of arts. Improvements in computer technology in the areas related to the professional activities of designers contribute to the dissemination and further development of new types of computer programs that help to unlock the capabilities of multimedia, increase their power, accessibility to use in urban design and individual creativity. The latest innovative developments include the creation of augmented reality, which enables the viewer to get in touch with the work of the designer and even to take part its creation.

Nowdays, there are several definitions of augmented reality, however, it was researcher Ronald Azuma (1997) who proposed the basic functions of augmented reality system, which: 1 )generates the necessary images in real time; 2) combines a virtual concept with the reality of display; 3 ) creates necessary projections using 3D images.

Developing in many directions, augmented reality becomes a cultural phenomenon of the 21st century. In today's context, augmented reality is most proven in the following potential areas: robotic offers; visualization of tourist routes; entertainment; military sphere and aviation navigation; marketing offers and other. As an example:

- health care: 1) with the help of video projection the necessary human organ reproduces so that the doctor can make an accurate diagnosis; 2) With the WallFX design system, multimedia special effects are created that can be projected to almost any surface, creating an interactive composition which can entertain children in hospitals. Special sensory programs help stimulate or relax, and can offer therapeutic elements for the rehabilitation of people with physical and cognitive problems.

- Project activity in the field of architecture and design of the object-spatial environment. The creativity of each of the masters corresponds to the personal 
vision of the concept of video images. As an example, Belgian artist Naziha Mestaoi constructed virtual reality projections for the 21 st climate conference on the city's famous historical sites (Paris, 2015). According to the concept of the author, viewers are given the opportunity to create a digital tree that they can see as it grows on the facades of buildings at the same rhythm with their heart. The composition of the video projections is formed by a pulse sensor, which is controlled via a smartphone. The author in the formation of video images proposes the concept of visual organization of figurative expression, abstraction, which reveals the most characteristic features of trees and negligible details are discarded. In transforming the form, artist Naziha Mestaoi uses the technique of hyperbolization, the increase in the size of individual elements, as well as the technique of drawing images.

- Education: 1) video projections provide a demonstration of the necessary materials in three-dimensional space, thus forming an interaction between the real world and the world of augmented reality; 2) acceleration to adaptation of children in new interactive learning conditions; 3 ) shortening of time for presentation of educational material; 4) possibility of changes of positions of the given forms, angles of rotation.

It should be noted that the main difference between augmented reality and virtual reality is the partial immersion of the viewer into the virtual dimension. Thus, playing interactive compositions leads to augmentation of reality, but not to its replacement.

\title{
ДНІПРО ЯК ПРЕДМЕТ АРХІТЕКТУРИ
}

\author{
Гулієв Логман Мубаріз огли \\ Придніпровська академія будівництва та архітектури \\ УКРAÏHA
}

Мета: проаналізувати архітектуру міста; визначити основні стилі та рішення.

Актуальність: Дніпро - це місто-архітектурна спадщина. Історія створення міста, його видатні мешканці та історичні події формують своєрідну, нічим не схожу на інші архітектуру.

Результати роботи:

Ретельно вивчивши історичні та архітектурні аспекти будівництва міста, ми дійшли таких висновків:

1. Історія Дніпропетровщини бере свій початок ще до н.е., але поселення на цій території почали з'являтися у період після війни з османською імперією у 1735-1739 роках. Офіційно місто було засновано під час поїздки Катерини II ново завойованими територіями, коли вона заклала перший камінь у фрундамент Преображенського собору 9 травня 1787 року. Отже, архітектура міста почалася зі споруди, яка мала бути виконана у грецькому або римському стилі, прототипом якої мав виступити храм Сан-Паоло-фуори-ле-Мура. Але у зв'язку з початком війни будівництво було зупинено и після повторної заклади храм був побудований у класицистичному стилі [5]. 
2.В цілому, вулиці Дніпра виконані у стилі класицизму, Катеринославському цегловому стилі, модерні, Сталінському ампірі та ін.

Будівлі міста прикрашають дерев'яні фрігурні двері кінця 19 - початку 20 віків, що були встановлені у так званий «Золотий вік Катеринославу». Всі двері, що збереглися з тих часів можна умовно розділити на двері громадських будівель та двері приватних будівель. Всі двері виконувалися з дерева 3 накладними металевими елементами - дверними ручками, номерами, накладками на паз для поштової скриньки. Всі двері були двостулковими. Візуальне рішення дверей відповідало естетичним уявленням епохи еклектики. Загальний дверний проріз візуально поділявся на дві нерівні частини (приблизно 1: 3 або 1: 4), з яких нижня частина, що складалася з двох стулок, була власне дверима, а верхня частина, кріпилася «намертво» і мала суто естетичне значення [1].

3. На фасадах будівель створена велика кількість скульптур, що зображають птахів, левів, звірині, чоловічі, жіночі голови та багато інших. Зображення птахів в катеринославському декорі, за невеликими винятками, не знаходять чіткого логічного пояснення. До сих пір є загадкою, чому вони були поміщені на фрасади: з якою метою і що означають в кожному конкретному випадку. Ймовірно, як і в випадку з левиними головами, химерами, жабами, приміщення птахів на фрасад було виключно примхою власника будівлі [3].

4. Також у архітектурі міста використовувалися різноманітні вежу, але 3 настанням радянської епохи тема веж на деякий час вийшла з ужитку, розповідає Максим Кавун. - Справа в тому, що конструктивізм, стиль 1920-х початку 1930-х років, робив наголос на кубатуру будівлі, на геометрично правильні композиції і не дуже «любив» вежі. Тим більше, повністю відкидалися вишукані фоорми завершень будинків дореволюційної епохи. Однак бували і рідкісні винятки. В середині 1920-х років відомий міський архітектор Олександр Красносельський спроектував дивовижне будівництво, яке не збереглося до наших днів. Це універмаг «Пайторг» на розі проспекту Карла Маркса (нині Яворницького) і вулиці Торгової (Ширшова, нині Липинського). Прямокутник універмагу займав кутову частину кварталу, а на ньому височіла виразна вежа. Аналогів подібної споруди в міській архітектурі більше не було.

У післявоєнний період архітектура міста доповнилася сталінськими ампірами [4; 2].

Висновки: Дніпро зберегло архітектурні рішення усіх епох, через які пройшло. Фасади міста виконані у стилях класицизму, Катеринославському цегловому стилі, модерні, Сталінському ампірі та ін. Важливими архітектурними складовими є оформлення дверей, скульптури та обрамлення будівель виконані у різні часи згідно з різними стилями. Тож місто не можливо вважати позбавленим архітектурної спадщини.

1. Dnipro.Retrieved

\section{Список використаних джерел:}

https://ru wikipedia org/wiki/\%D0\%98\%D1\%81\%D1\%82\%D0\%BE\%D1\%80\%D0\%B8\%D1\%8F \%D0\%B3\%D0\%BE\%D1\%80\%D0\%BE\%D0\%B4\%D0\%B0_\%D0\%94\%D0\%BD\%D0\%B5\%D0\% BF\%D1\%80\%D0\%B0\#\%D0\%98\%D1\%81\%D1\%82\%D0\%BE\%D1\%80\%D0\%B8\%D1\%87\%D0 \%B5\%D1\%81\%D0\%BA\%D0\%B8\%D0\%B9_\%D0\%BE\%D0\%B1\%D0\%B7\%D0\%BE\%D1\%80

2. Retrieved from https://gorod.dp.ua/news/107006 
3. Retrieved from https://gorod.dp.ua/news/124485

4. Retrieved from https://gorod.dp.ua/news/123202

5. Retrieved from https://gorod.dp.ua/news/111814

\title{
ДОЖДЕВЫЕ САДЫ КАК СОСТАВЛЯЮЩАЯ ЧАСТЬ УСТОЙЧИВОГО РАЗВИТИЯ ГОРОДА
}

\begin{abstract}
Киселёва А.B.
старший профессор кафедры Градостроительства Архитектурно-художественный институт. Одесская государственная академия строительства и архитектуры
\end{abstract}

Крамаренко М.O. студент группы А-320т Архитектурно-художественный институт. Одесская государственная академия строительства и архитектуры

УКРАИНА

Зарождение и развитие процессов урбанизации оказало существенное воздействие на фуннкционирование малых и средних водотоков городского поверхностного стока посредством значительного преобразования поверхности водосборной площади. В связи с загрязнением ливневых вод, наводнениями и другими воздействиями оказывается серьёзное воздействие на качество городской среды [1]. В долгосрочной перспективе необходимо вкладывать средства в устойчивую инфраструктуру, обновить городские системы и провести посадки зелёных насаждений. Управление ливневыми стоками позволяет применить комплексный подход к решению этой проблемы, повысить экономическую эфрфективность. Однако инвестиции в эту проблему имеют долгосрочный характер, альтернативным решением проблемы может стать устройство дождевых садов в городском пространстве.

Протекая по крышам зданий и асфальту, воды поверхностного стока поглощают накопленное данными поверхностями тепло, вызывая впоследствии тепловое загрязнение принимающего водоёма или водотока. Установлено, что средняя температура малого водотока возрастает на $0,08^{\circ} \mathrm{C}$ при увеличении доли водосборной площади, занятой водонепроницаемым покрытием, на 1\% [2]. Существующие технологии обработки и очистки городского стока являются довольно дорогостоящими. Они осуществляют лишь его химическую очистку, не решая проблемы изменения гидрологического режима. Перспективным и всё более широко используемым методом смягчения влияния городского стока на экосистемы является обустройство дождевых садов.

Прямое назначение дождевых садов - обеспечение естественной фильтрации дождевых потоков. Помимо этого, дождевой сад несет в себе и эстетическую функкцию улучшения городского пространства. Дождевой сад как 
элемент зелёной инфраструктуры представляет собой пониженную область в ландшафте, где собирается дождевая вода и проходя процесс гидроботанической очистки (фиторемедиация) способствует увеличению биоразнообразия, созданию отдельных биоценозов, где протекают естественные биологические процессы.

При создании дождевых садов с особым вниманием нужно отнестись и квыбору растений, почв и системности всей конструкции Растения однозначно должны быть адаптированы к сухим, влажным или затопляемым почвам, а также обрабатывать разное количество воды. Во время больших осадков растения работают с почвой дождевого сада и замедляют сток воды. Видовое разнообразие растений, которые будут отобраны, естественно, зависит от климата местности и территории размещения сада, для дождевого сада в городском пространстве и такого же сада, спроектированного у водоема выбор растений будет разным.

Есть, однако, критерии, которые применяются во всех случаях:

- лучше всего использовать местные растения, поэтому предварительно необходимо провести анализ имеющейся растительности. Но местные растения не единственный вариант, в дождевом саду могут произрастать и неинвазивные виды.

- в большинстве дождевых садов, как правило, высаживаются деревья, древесные кустарники или травянистые многолетники, не исключены и однолетники.

- в выборе растений для дождевого сада приоритетом является не сезонная эстетика, цвет, или текстура, а минимальный уход за растениями и садом в целом.

- растения должны быть терпимы к засухе и временному застою дождевой воды. Они также должны быть длиннокорневищными, устойчивыми к влаге и избытку загрязняющих и биогенных веществ.

В мире дождевые сады как объекты фриторемедиации создаются уже около 40 лет. По всему миру дождевые сады входят в программу устойчивого развития города. Так, в США развиты такие направления как «Экологическое Управление Ливневыми стоками» (Ecological Stormwater Management - ESM), а также «Low Impact Design - LID» (технология экологически щадящего подхода к дизайну территории, цель которого - управление городскими ливневыми стоками). В Великобритании есть похожая программа «Устойчивые дренажные системы» (Sustainable Drainage Systems SuDS), в Австралии развита технология управления ливневыми стоками «Water Sensitive Urban Design - WSUD». Все эти подходы направлены на создание устойчивой системы городского дренажа, и дождевые сады здесь являются ключевым элементом [3].

Современные исследования показали, что биодренажные конструкции (в составе больших по площади садов и парков) могут быть эфффективными для улучшения качества воды и для сохранения гидрологической функции, даже когда температура воздуха опускается ниже нуля. Исследования доказывают, что при правильном анализе участка, тщательном проектировании и ответственном подборе растений биодренажные системы могут хорошо работать даже в регионах с холодным климатом. Если рассматривать 
дождевые сады как часть городского пространства то можно сделать вывод, что такой сад имеет преимущественно прямоугольную фрорму и вертикальные бордюры, их можно устанавливать вдоль инженерных сетей, улиц, линии роста деревьев и других уличных объектов. Вода в них попадает напрямую с улиц города, тротуаров и других асфальтированных или мощеных поверхностей. Обычно это выносливые и эстетически приятные глазу растения вкупе с впитывающими влагу материалами, которые приспособлены к суровым городским условиям и особенностям ухода за улицей зимой (например, использованию соли на тротуарах в зимние месяцы)».

В итоге, хотелось бы сказать, что дождевой сад - это эфффективное биоинженерное решение проблемы затопления территорий, а также очищения загрязненных дождевых потоков. Дождевые сады не могут полностью заменить систему водоотведения, они дополняют и совершенствуют ее, обеспечивая стабильную работу. Помимо выполнения своих основных функций дождевые сады имеют и эстетическую составляющую - это прекрасные элементы украшения, прогулочных дорожек в парке, городских улиц, дорог и общественных зданий.

\section{Список используемых источников:}

1. Christopher, J. Walsh, Tim, D. Fletcher \& Anthony, R. Ladson. Stream restoration in urban catchments through redesigning stormwater systems: looking to the catchment to save the stream. Journal of the North American Benthological Society. 2005. №24(3), 690-705

2. Фролова, Н. Л.(2018). Гидрология рек. Антропогенные изменения речного стока. Москва: Юрайт.

3. Дождевые сады как элемент системы устойчивого развития города. Изъято из http://zvt.abok.ru/upload/pdf_articles/369.pdf.

4. Сады у Залива. Изъято из https://planetofhotels.com/singapur/singapur/sady-u-zaliva. 


\section{ШРИФТ У КОНЦЕПЦІЇ НЕОПЛАСТИЦИЗМУ}

Ісмайлова Марія Сергіївна

кандидат мистецтвознавства, викладач кафедри графічного дизайну Харківської державної академії дизайну і мистецтв

УKPAÏHA

На початку XX ст. у Голландії з'явилося творче об'єднання архітекторів і художників «De Stijl». Цю групу і журнал з такою самою назвою «De Stijl» заснували 1917 року голландські майстри: архітектор і художник Т. ван Дусбург, художник Б. ван дер Лек, архітектор П. Оуд, художник П. Мондріан; бельгійський художник, скульптор і архітектор Ж. Вантегерло; угорський художник В. Хусар та ін.

Ядром художньої концепції руху «Де Стейл» була концепція неопластицизму. За ствердженням російської дослідниці О. Ващук, метою неопластицизму було звільнення існуючих фрорм від ілюзорного «шуму», який спотворював об'єктивну гармонію світу. Неопластицисти були переконані, що помилковий, надлишковий і суперечливий образ дійсності вводить людину в оману, травмує її свідомість. Вихід з цієї трагічної і аморальної ситуації неопластицисти бачили у виявленні фундаментальних законів фооми у вигляді абстрактних мальовничих формул [Ващук, 2009].

Характеризуючи дизайнерські вподобання представників групи «De Stij|», відомий український дизайнер і дослідник О. Бойчук зазначав: «Набір зображувальних засобів, за допомогою яких члени групи демонстрували "справжню версію чистої реальності" й "звільняли життєві відносини від тягаря природних фрорм", був край обмеженим. Прямокутні площини, пофарбовані трьома спектральними кольорами (червоний, синій, жовтий) і три "не кольори" (чорний, білий, сірий) плюс чорні лінії під кутом 90 градусів - так виглядала первинна схема формоутворення» [Бойчук, 2013, с. 118].

Для створення поліграфічної продукції Т. ван Дусбург розробив універсальний шрифт De Stijl (рис. 1). Цей моноширинний гротеск мав гранично спрощену форму літер, наближену до прямокутника. Завдяки чистоті форми, він гармонійно вписувався у графічні рішення обкладинок, елементів ідентифікації тощо. Послідовні в реалізації своєї концепції, розробники запропонували ще дві варіації накреслення цього шрифту: напівжирного й широкого накреслення. Завдяки тому, що шрифти належали до однієї групи, вони гарно співіснували в одній композиції, допомагаючи здійснювати вирівнювання по ширині, що також було не випадково, оскільки дозволяло наблизити загальний абрис шрифтового блоку до квадрата або прямокутника.

Шрифт De Stijl був дуже популярним у графічних розробках прихильників неопластицизму, але шрифтова палітра їхніх робіт не обмежувалася лише цією гарнітурою. Т. ван Дусбург, В. Хусар, Б. ван дер Лек й інші майстри у дизайні плакатів, обкладинок і розгортів використовували також інші оригінальні й акцидентні шрифти. Ці прості за накресленням, але водночас дуже яскраві шрифти якнайкраще відповідали концепції чистих фрорм, гарно співпрацювали зі спрощеними, стилізованими зображеннями. Наприклад, у рекламному плакаті для маслозаводу в Дельфті (Голландія) Б. ван дер Лек 
використав акцидентну гарнітуру шрифту, де кожен елемент літери розташований окремо за принципом трафарету й складається в єдине ціле в техніці мозаїки. Цей шрифт гарно працює зі стилізованим зображенням чоловічої фігури, яка також трактована за допомогою простих розрізнених геометричних фігур (рис. 2).

Також яскравим прикладом оригінальної шрифтової розробки є рубаний геометричний шрифт, що його запропонував Т. ван Дусбург у логотипі журналу «De Stijl» (рис. 3). Літери складаються із близьких за розміром прямокутників із заокругленими кутками й також нагадують трафарет. Яскравим прикладом типографіки руху «Де Стейл» $€$ шрифтова листівка Б. ван дер Лек, де акцидентний шрифт різної ширини й висоти також побудований за принципом мозаїки. Шрифтові написи вписані у прямокутні статичні фрорми, а вирівнювання так само організує текст по ширині (рис. А. 2-3).

При всьому розмаїтті характерів і образних якостей шрифтів помітно, що всі використані гарнітури належать до категорії гротесків. Спрощені форми літер, поєднання рівнотовщинних основних і допоміжних штрихів і тяжіння до форми прямокутника як у формі літер, так і у загальному компонуванні шрифтових блоків на площині - ось основні характерні риси шрифтових форм неопластицизму.

Серед популярних прийомів, що їх застосовували представники руху «Де Стейл», варто назвати використаний Т. ван Дусбургом у дизайні журнального розгорту прийом накладання шрифту на кольорову плашку зі зміною кольору (у цьому разі - з чорного на білий, завдяки чому отримано ефект іррадіації) (рис.4). Це безперечно свідчить про футуристичний вплив на творчість представників руху. Також запозиченим $€$ прийом пошарового накладання шрифтів і текстових блоків, завдяки чому створюється ілюзія глибини простору (рис.4). Цей прийом використовували як футуристи, так і дадаїсти, що вказує на дифузне взаємопроникнення композиційних засобів і прийомів у стилях і напрямах раннього модернізму.

Отже, представники руху «Де Стейл» намагалися обмежуватися використанням простих шрифтових гарнітур, позбавлених усього зайвого (засічок, заокруглених переходів і сполучень, інших нюансів форми), частіше за все обираючи гротески. Популярним прийомом створення акцидентних шрифтів $є$ членування форми літери на прості геометричні складові, завдяки чому літера отримує трафаретну структуру. Під час вибору готових шрифтів і розробки власних оригінальних шрифтових рішень неопластицисти віддавали перевагу моноширинним гротескам, які найбільше відповідали концепції простих форм. Для шрифтів руху «Де Стейл» формотворчими були принципи абстрагування й стилізації, за допомогою яких створювалися нові «геометризовані» форми літер.

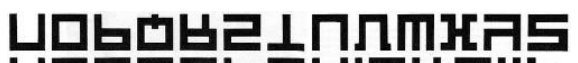

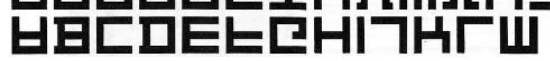

Рис. 1. Т. ван Дусбург. Шрифт «Де Стиль». Голландія. 1917 р.: https://zaidadi.wordpress.com/.

Рис.2. Б. ван дер Лек. Рекламний плакат (фрагмент). Голландія. 1919 р.: https://zaidadi.wordpress.com/ 
December 13, 2019 • Valletta, Republic of Malta • 93
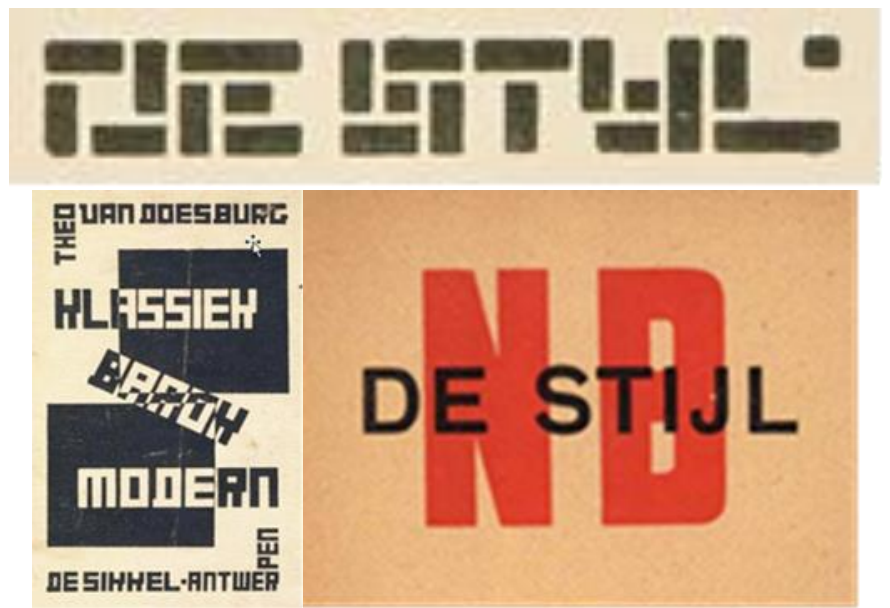

Рис. 3. Т. ван Дусбург. Логотип журналу «Де Стиль». Голландія. 1917 р. https://www.widewalls.ch/de-stijl-neoplasticism/

Рис. 4. Т. ван Дусбург. Сторінка журналу «Де Стиль» (фрагмент). Голландія. 1920 р.: https://zaidadi.wordpress.com/

Рис. 5. T. ван Дусбург. Обкладинка журналу «De Stijl» (фрагмент). Голландія. 1921 р. : https://zaidadi.wordpress.com/

\section{Список використаних джерел:}

1. Бойчук, А.В. Пространство дизайна. Харьков: Нове слово, 2013. 367 с.

2. Ващук, О.А. Развитие модульной системы проектирования в графическом дизайне Швейцарии : от новой типографики к международному стилю. Вестник ВятГГГУ. 2009. № 4. C. 197-205.

3. https://www.widewalls.ch/de-stijl-neoplasticism/

4. https://zaidadi.wordpress.com/ 


\title{
SECTION XVII. MILITARY SCIENCES, NATIONAL SECURITY AND SPORT
}

\section{ОСОБЛИВОСТІ ПРОЦЕСУ ПРИЙНЯТТЯ РІШЕНЬ В УМОВАХ НЕСТОХАСТИЧНОÏ НЕВИЗНАЧЕНОСТІ}

\begin{abstract}
НАУКОВО-ДОСЛІДНА ГРУПА:
Королюк Наталія Олександрівна канд. техн. наук, доцент, доцент кафедри бойового застосування та експлуатації АСУ Харківський національний університет Повітряних Сил

Голубничий Дмитро Юрійович канд. техн. наук, доцент, доцент кафедри бойового застосування та експлуатації АСУ Харківський національний університет Повітряних Сил

Коршець Олена Антонівна канд. техн. наук, заступник начальника кафедри Повітряних Сил Національний університет оборони України

Першин Олександр Васильович викладач кафедри бойового застосування та експлуатації АСУ

Харківський національний університет Повітряних Сил

Маслійова Софрія Олександрівна
здобувач вищої освіти факультету АСУ та НЗПА
Харківський національний університет Повітряних Сил
УКРАЇНА
\end{abstract}

Аналіз локальних військових конфрліктів останнього десятиліття двадцятого і початку двадцять першого століть дозволяє зробити висновок, що вдосконалення системи протиповітряної оборони України $є$ в даний час однієї з важливих завдань військового будівництва [1-3].

В ході ведення операції одним з вирішальних умов організації та успішного проведення протиповітряної оборони об'єктів, своїх військ є обґрунтоване і своєчасне прийняття рішень на застосування сил і засобів за результатами оцінки повітряного противника [2]. В ході нанесення удару з повітря сторона, яка наносить удар (далі - противник), намагається досягнути певної мети. Метою може бути зміна політичного спрямування влади в країні-об'єкті удару, порушення її територіального суверенітету, реалізація економічних інтересів тощо. Мета визначається органами державного та військового управління противника на етапі формування замислу операції, відповідно, являється визначеною (детермінованою) для противника та невизначеною для сторони, по якій завдається удар. Оскільки мета операції багато в чому буде визначати форми і засоби застосування військ противника та об'єкти його удару, розпізнавання цієї мети якомога раніше $є$ важливим завданням для органів управління протиповітряною обороною держави. Це дозволить зменшити рівень невизначеності відносно варіанта замислу дій повітряного противника, 
та дасть можливість вибрати раціональний варіант дій своїх військ щодо прикриття від ударів з повітря тих об'єктів, по яким буде наноситись удар, й своєчасно визначити (уточнити) завдання підпорядкованим військам. Проблема полягає у пошуку методів розпізнавання замислу дій противника, у знаходженні логічних закономірностей діяльності органів управління, які дозволять розпізнати об‘єкти удару, а з них знайти можливі варіанти ієрархії цілей дій повітряного противника, які розкривають його замисел.

Отже, існує необхідність удосконалення підходів щодо визначення закономірностей, що зв'язують сукупність розпізнаних об‘єктів повітряного удару з ієрархічними цілями операції, які на підставі аналізу розвідувальних даних розкриють замисел дій повітряного противника.

Розпізнавання замислу дій повітряного противника є найбільш складною та слабо структурованою задачею, яка стоїть перед особою, що приймає рішення, в ході підготовки та веденні операції. На теперішній час ії рішення лежить в площині емпіричних знань людини, що на основі отриманої різнорідної інформації і власного досвіду та інтелекту, викриває замисел його дій. Однак, розвиток методів штучного інтелекту для рішення слабо структурованих задач, а також використання теорії нечітких множин дозволило реалізувати задачу розпізнавання замислу дій повітряного противника у складі системи підтримки прийняття рішення (СППР) [2].

Прийняття рішення щодо розпізнавання замислу дій повітряного противника відноситься до класу задач прийняття рішення в умовах природної, і поведінковою невизначеністю $[3,4]$. Природна невизначеність передбачає аналіз подій, які не носять масового характеру, тому не можуть бути описаними імовірнісними законами, а ситуації, що розглядаються при підготовці, прийнятті рішень, є унікальними. Такі ситуації, явища, події необхідно враховувати при прийнятті рішення, тому що застосування детермінованих методів теорії дослідження операцій може привести до значних помилок.

Висновки. Таким чином, при організації процесу управління виникає протиріччя між необхідністю обробки інформації з нестохастичною (природною і поведінковою) невизначеністю та відсутністю ефективних методів ії обробки для забезпечення прийняття рішень, що спрямовані на раціональне виконання поставлених задач. Отже, в процесах підготовки й прийняття рішень виникає задача - розроблення методики розпізнавання замислу дій повітряного противника з застосуванням СППР, яка дозволить приймати раціональні за ефрективністю бойових дій, рішення з врахуванням існуючих ресурсних обмежень на ведення операції

\section{Список використаних джерел:}

1. Пермяков, О.Ю. \& Сбітнєв, А.І. (2008). Інформаційні технології і сучасна збройна боротьба. Знання, (3), 204-208.

2. Даник, Ю.Г. \& Пермяков, О.Ю. (2018). Сучасні інфрормаційні технології в забезпеченні національної безпеки і оборони. Сучасні інфрормаційні технології у сфері безпеки і оборони, 159-174.

3. Біла книга - 2018. Збройні Сили України. (2018). Київ: МОУ.

4. Королюк, Н.О., Першин, О.В., Грідньова, Т.О. \& Шевченко, С.О. (2019). Обгрунтування сучасного підходу щодо автоматизації процесів прийняття рішень по управлінню авіацією. Збірник наукових пращь, 1(59), 32-39. 
NOTES 


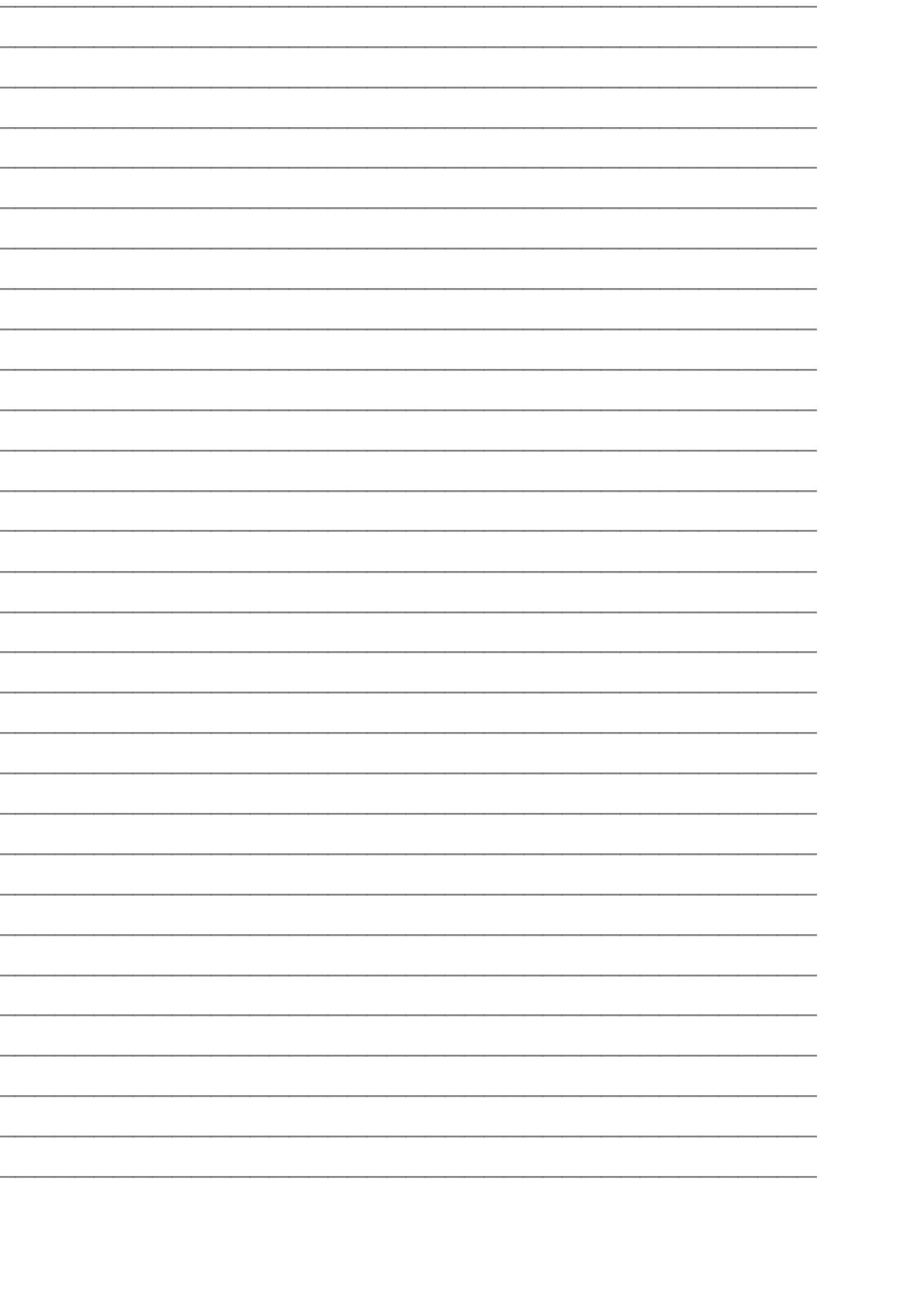





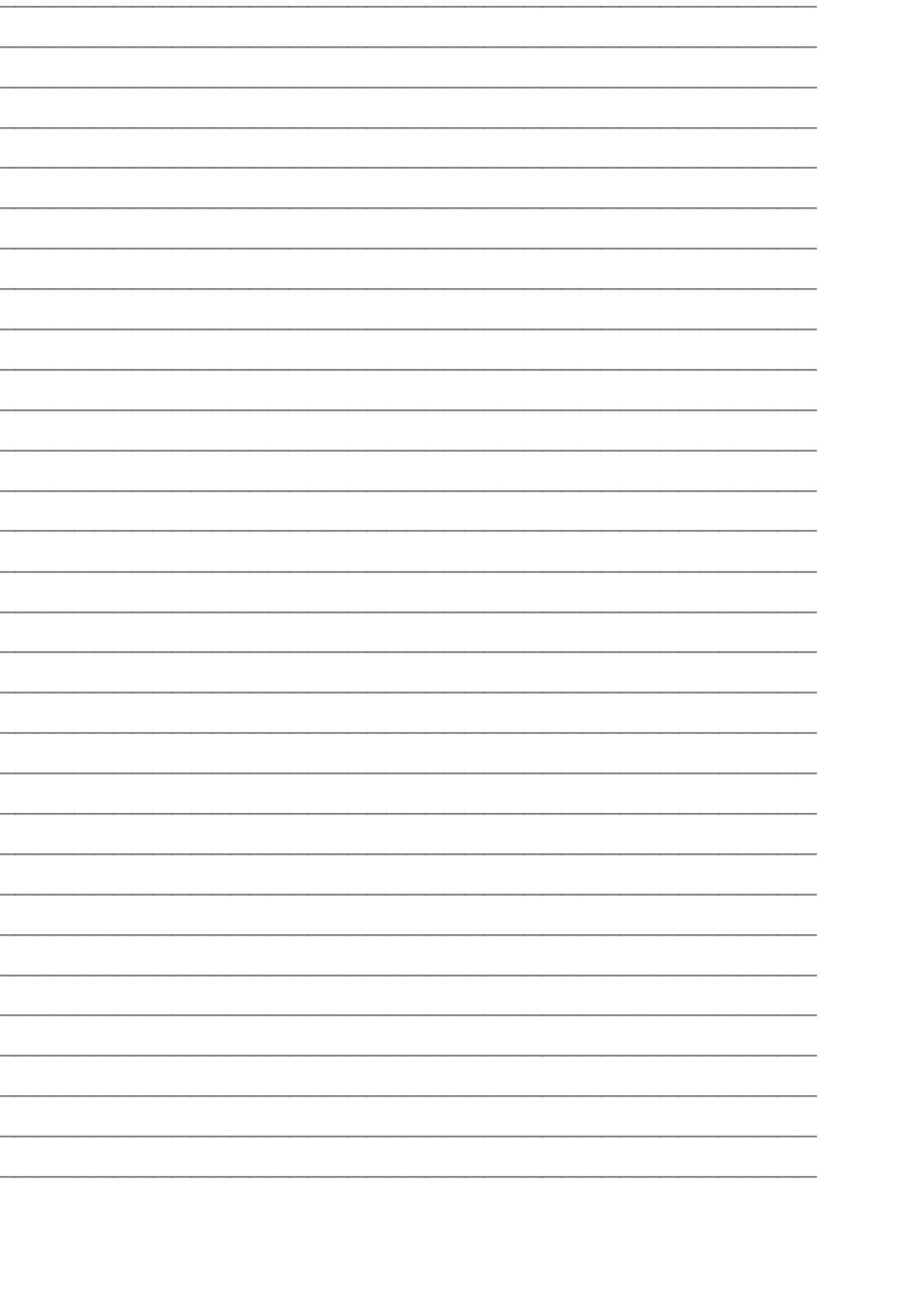




\section{КОГОГ}

COLLECTION OF SCIENTIFIC PAPERS

WITH PROCEEDINGS OF THE INTERNATIONAL SCIENTIFIC AND PRACTICAL CONFERENCE

\section{«PROBLEMS AND PROSPECTS OF IMPLEMENTATION OF INNOVATIVE RESEARCH RESULTS»}

December 13, 2019 • Valletta, Republic of Malta

\section{VOLUME 4}

\section{English, Ukrainian and Russian}

All papers have been reviewed

Organizing committee may not agree with the authors' point of view Authors are responsible for the correctness of the papers' text

Signed for publication 13.12.2019. Format $60 \times 84 / 16$.

Offset Paper. The headset is Arial. Digital printing.

Conventionally printed sheets 5,81 .

Circulation: 100 copies.

Printed from the finished original layout.

Contact details of the organizing committee:

21037, Ukraine, Vinnytsia, Zodchykh str. 18, office 81

NGO European Scientific Platform

Tel.: +38098 1948380; +38098 1956755

E-mail: info@ukrlogos.in.ua

URL: www.ukrlogos.in.ua 